\title{
WILD HORSE 69-KV TRANSMISSION LINE ENVIRONMENTAL ASSESSMENT
}

\author{
Prepared by
}

\section{DEPARTMENT OF ENERGY}

\author{
RECEIVED \\ FEB 241997 \\ OPFI
}

DECEMBER 1996

MASTER

DISTPIDUTION OF THIS DOCUMENT IS UNLMITED $\mathrm{Kg}$ 
TABLE OF CONTENTS

\title{
HILL COUNTY ELECTRIC COOPERATIVE
}

\author{
Wild Horse 69-kV Transmission Line Environmental Assessment
}

Section

Page

1

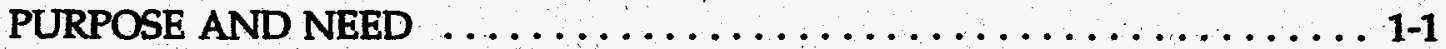

1.1 Introduction $\ldots \ldots \ldots \ldots \ldots \ldots \ldots \ldots \ldots \ldots \ldots \ldots \ldots \ldots, 1-1$

1.2 Project Description ............................ 1-2

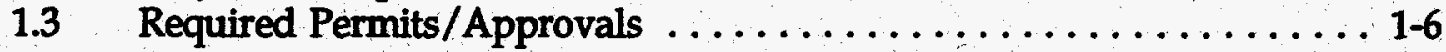

1.3.1 International Boundary Commission .............. 1-6

1.3.2 Rural Utilities Service (RUS) $\ldots \ldots \ldots \ldots \ldots \ldots \ldots \ldots \ldots \ldots$ 1-7

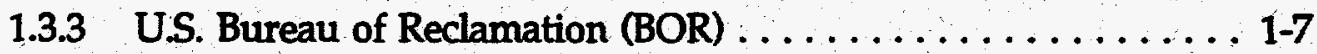

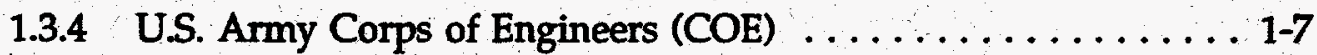

1.3.5 U.S. Fish \& Wildlife Service (FWS) $\ldots \ldots \ldots \ldots \ldots \ldots \ldots \ldots$ 1-7

1.3.6 Western Area Power Administration (WAPA) ... . . . . . 1-8

1.3.7 U.S. Natural Resources Conservation Service (NRCS) . . . . . . 1-8

1.3.8 U.S. Bureau of Land Management (BLM) $\ldots \ldots \ldots \ldots \ldots \ldots \ldots$

1.3.9 Montana State Land Board (SLB) . . . . . . . . . . . . . . 1-8

1.3.10 State Historic Preservation Office (SHPO) ... . . . . . . . 1-9

1.3.11 Montana Department of Environmental Quality (DEQ) . . . . . 1-9

1.3.12 Montana Department of Fish, Wildlife \& Parks (FWP) . . . . . 1-9

1.3.13 Hill County Conservation District .............. 1-9

1.3.14 Hill County Weed Department ............... 1-10

1.4 Canadian Regulatory Actions $\ldots \ldots \ldots \ldots \ldots \ldots \ldots \ldots \ldots \ldots \ldots$

2 PROPOSED ACTION AND ALTERNATIVES $\ldots \ldots \ldots \ldots \ldots \ldots \ldots \ldots .2-1$

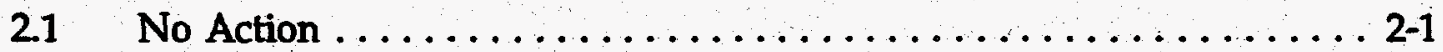

2.2 Proposed Action - Express Route Alternative ............. 2-1

2.2.1 Route Description . . . . . . . . . . . . . . 2-1

2.2 .2 North Gilford Substation Additions ............. 2-3

2.2.3 Applicant's Proposed Mitigation Measures .......... 2-4

$2.3 \quad$ Northwestern Route Alternative .................... 2-8

2.3.1 Route Description ..................... 2-8

2.3.2 Applicant's Proposed Mitigation Measures .......... 2-8

2.4 Cottonwood Route Alternative .................. 2-8

2.4 .1 Route Description . . . . . . . . . . . . . .

2.4.2 Applicant's Proposed Mitigation Measures ......... 2-9

3 AFFECTED ENVIRONMENT $\ldots \ldots \ldots \ldots \ldots \ldots \ldots \ldots \ldots \ldots \ldots \ldots \ldots \ldots \ldots \ldots \ldots \ldots$

3.1 Proposed Express Route Alternative . . . . . . . . . . . . $3-1$

3.1.1 Air Quality . . . . . . . . . . . . . . . . .

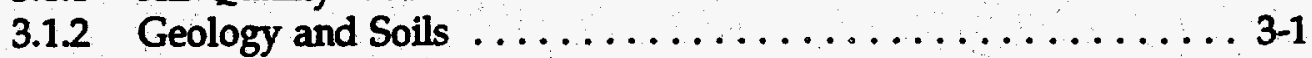

3.1.3 Surface Water and Floodplains ............... 3-2

3.1 .4 Wetlands ........................ 


\section{Continued}

Section

3.1.5 Aquatic Ecology $\ldots \ldots \ldots \ldots \ldots \ldots \ldots \ldots \ldots \ldots, 3-2$

3.1.6 Vegetation $\ldots \ldots \ldots \ldots \ldots \ldots \ldots \ldots \ldots \ldots \ldots \ldots \ldots \ldots \ldots \ldots \ldots, 3-3$

3.1 .7 Wildlife $\ldots \ldots \ldots \ldots \ldots \ldots \ldots \ldots \ldots \ldots \ldots \ldots \ldots \ldots \ldots \ldots \ldots, 4$

3.1.8 Existing and Planned Land Use $\ldots \ldots \ldots \ldots \ldots \ldots \ldots \ldots .36$

3.1.9 Visual Resources $\ldots \ldots \ldots \ldots \ldots \ldots \ldots \ldots \ldots \ldots \ldots ., 3-6$

3.1.10 Cultural Resources $\ldots \ldots \ldots \ldots \ldots \ldots \ldots \ldots \ldots \ldots \ldots \ldots . \ldots \ldots$

3.1.10.1 Prehistory ........................ 3-7

3.1.10.2 Ethnography $\ldots \ldots \ldots \ldots \ldots \ldots \ldots \ldots \ldots \ldots .3-7$

3.1.10.3 Historic Context .................... 3-9

3.1.10.4 Prehistoric Resources . . . . . . . . . . . . . 3-10

3.1.10.5 Historic Resources .................... 3-11

3.1.11 Paleontological Resources ..................... 3-11

3.1.11.1 Judith River Formation Resources ........ 3-11

3.1.11.2 Technical Analysis and Field Survey ....... 3-12

3.1.12 Socioeconomic and Community Resources ........... 3-13

3.1.13 Transportation and Noise $\ldots \ldots \ldots \ldots \ldots \ldots \ldots \ldots . . \ldots \ldots .14$

3.1.14 Environmental Justice $\ldots \ldots \ldots \ldots \ldots \ldots \ldots \ldots \ldots \ldots . . \ldots \ldots .14$

$3.2 \quad$ Northwestern Route Alternative $\ldots \ldots \ldots \ldots \ldots \ldots \ldots \ldots \ldots \ldots, 3-14$

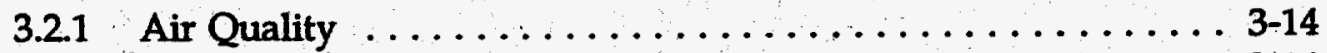

3.2.2 Geology and Soils ...................... 3-14

3.2.3 Surface Water and Floodplains $\ldots \ldots \ldots \ldots \ldots \ldots \ldots \ldots .3-15$

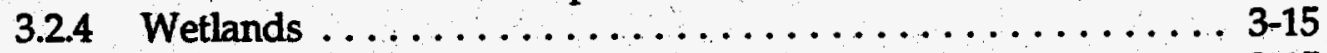

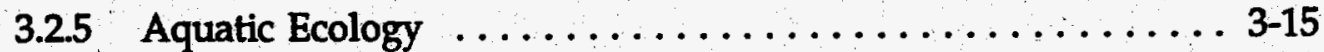

3.2.6 Vegetation ..............................

3.2 .7 Wildlife $\ldots \ldots \ldots \ldots \ldots \ldots \ldots \ldots \ldots \ldots \ldots \ldots \ldots \ldots \ldots \ldots \ldots \ldots \ldots, 17$

3.2. Existing and Planned Land Use $\ldots \ldots \ldots \ldots \ldots \ldots \ldots, 3-18$

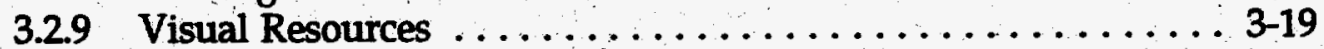

3.2.10 Cultural Resources $\ldots \ldots \ldots \ldots \ldots \ldots \ldots \ldots \ldots \ldots . . \ldots \ldots$

3.2.11 Paleontological ........................ 3-20

3.2.12. Socioeconomic and Community Resources $\ldots \ldots \ldots \ldots \ldots$ 3-20

3.2.13 Transportation and Noise $\ldots \ldots \ldots \ldots \ldots \ldots \ldots \ldots .3 .20$

3.2.14 Environmental Justice $\ldots \ldots \ldots \ldots \ldots \ldots \ldots \ldots \ldots \ldots \ldots . . \ldots \ldots$

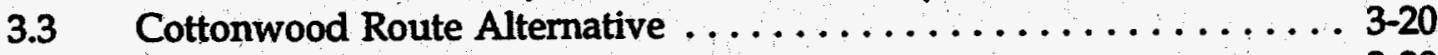

3.3.1 Wetlands $\ldots \ldots \ldots \ldots \ldots \ldots \ldots \ldots \ldots \ldots \ldots \ldots, 3-20$

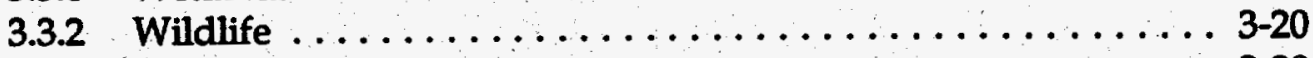

3.3.3 Cultural Resources $\ldots \ldots \ldots \ldots \ldots \ldots \ldots \ldots \ldots \ldots, 3-20$

$4 \quad$ ENVIRONMENTAL CONSEQUENCES $\ldots \ldots \ldots \ldots \ldots \ldots \ldots \ldots \ldots \ldots \ldots \ldots \ldots \ldots \ldots \ldots$

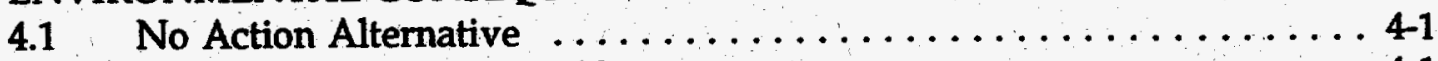

4.2 Proposed Express Route Alternative $\ldots \ldots \ldots \ldots \ldots \ldots \ldots \ldots \ldots \ldots \ldots \ldots \ldots \ldots \ldots \ldots$

4.2.1 Air Quality $\ldots \ldots \ldots \ldots \ldots \ldots \ldots \ldots \ldots \ldots \ldots \ldots \ldots \ldots \ldots \ldots, 1$

4.2.2 Geology and Soils . . . . . . . . . . . . . . . 


\section{Continued}

Section

Page

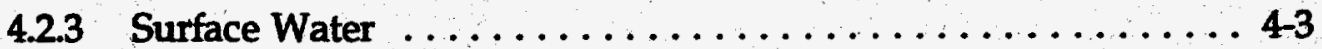

4.2.4 Wetlands .......................

4.2 .5 Aquatic Ecology $\ldots \ldots \ldots \ldots \ldots \ldots \ldots \ldots \ldots \ldots \ldots \ldots \ldots$

4.26 Vegetation ....................... 4.6

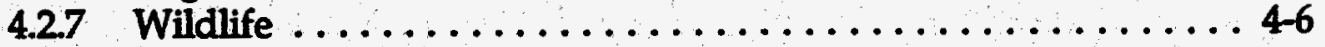

4.2.8 Existing and Planned Land Use . . . . . . . . . . . . . 4-7

4.2.9 Visual Resources $\ldots \ldots \ldots \ldots \ldots \ldots \ldots \ldots \ldots \ldots \ldots \ldots \ldots .7$

4.2 .10 Cultural Resources $\ldots \ldots \ldots \ldots \ldots \ldots \ldots \ldots \ldots \ldots \ldots . \ldots \ldots$

4.2.11 Paleontological Mitigation ................

4.2.12 Socioeconomic and Community Resources .......... 4-9

4.2.13 Environmental Justice ................... . 4-10

4.2.14 Safety and Electromagnetic Effects . . . . . . . . . 4-10

$4.3 \quad$ Northwestern Route Alternative ................ 4-11

4.3.1 Wetlands ......................... 4 411

4.3.2 Wildlife $\ldots \ldots \ldots \ldots \ldots \ldots \ldots \ldots \ldots \ldots \ldots \ldots \ldots \ldots \ldots$ 4-11

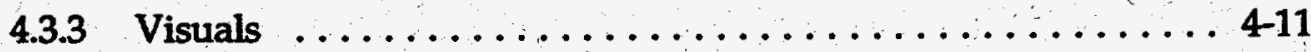

4.3 .4 Cultural ........................ 4-11

4.4 Cottonwood Route Alternative $\ldots \ldots \ldots \ldots \ldots \ldots \ldots \ldots \ldots \ldots$ 4-11

4.4.1 Wetlands ........................ $4-11$

4.4 .2 Visual ...........................

4.5 Summary of Impacts $\ldots \ldots \ldots \ldots \ldots \ldots \ldots \ldots \ldots \ldots \ldots \ldots \ldots \ldots$ 4-12

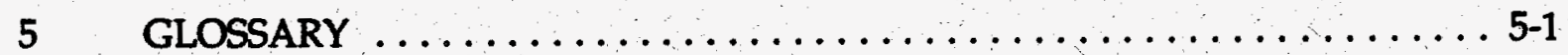

$6 \quad$ REFERENCES $\ldots \ldots \ldots \ldots \ldots \ldots \ldots \ldots \ldots \ldots \ldots \ldots \ldots \ldots \ldots \ldots \ldots \ldots$

\section{APPENDICES}
A Maps of Wetland Areas
B Plant Species
C Wildlife Species
D Correspondence
E Description of Construction 
Continued

\section{LIST OF TABLES}

2-1 Comparison of Length and Cost of Wild Horse Transmission Line Alternatives

4-1 Estimated Incremental Emissions from Power Generated for the Wild Horse Pumping Station Compared to 1994 Emissions at the Antelope Valley Generating Station

4-2 Modeled Ambient Impacts of the Antelope Valley Generating Station with Additional Generation to Support the Wild Horse Pumping Load

4-3 Construction Impacts/Alternative Route Selection Summary

4-4. Operation Impacts/Alternative Route Selection Summary

\section{LIST OF FIGURES}

1-1 Vicinity Project Area Map

1-2 TP-69G Transmission Line Pole

1-3 TH-5GD Transmission Line Pole

2-1 Map of Alternate Routes

2-2 Map of North Gilford Substation 


\subsection{Introduction}

Hill County Electric Cooperative Inc. (Hill County) proposes to construct and operate a 69-kV transmission line from its North Gildford Substation in Montana north to the Canadian border. A vicinity project area map is enclosed as Figure 1-1. TransCanada Power Corporation (TCP), a Canadian power-marketing company, will own and construct the connecting 69-kV line from the international border to Express Pipeline's pump station at Wild Horse, Alberta.

This Environmental Assessment is prepared for the Department of Energy (DOE) as lead federal agency to comply with the requirements of the National Environmental Policy Act (NEPA), as part of DOE's review and approval process of the applications filed by Hill County for a DOE Presidential Permit and License to Export Electricity to a foreign country.

The purpose of the proposed line is to supply electric energy to a crude oil pump station in Canada; owned by Express Pipeline Ltd. (Express). The pipeline would transport Canadian-produced oil from Hardisty, Alberta, Canada, to Casper, Wyoming. The Express Pipeline is scheduled to be constructed in 1996-97 and will supply crude oil to refineries in Wyoming and the midwest.

Express originally proposed diesel engines to power the Wild Horse station, since, at that time, it was not aware of any electric transmission systems sufficiently close to the Wild Horse station site to make powering the station with electricity economically feasible. Subsequently, after discussions with Hill County, Express reevaluated the feasibility, economics and potential air quality benefits of powering the Wild Horse station with electricity, as the other eight pumping stations on the Express Pipeline would be. Powering the Wild Horse station with electricity would be feasible by tapping into the Hill County Electric Cooperative $69-\mathrm{kV}$ line located less than 15 miles from the international border.

Hill County, a rural utility headquartered in Havre, Montana, has a service area encompassing parts of five counties in north central Montana. These include the counties of Hill, Liberty, Chouteau, Blaine, and Fergus. The Cooperative provides power to 127 commercial loads, 1000 KVA or less, which vary from oil and gas related loads to Hutterite Colonies. The remaining loads served are irrigation pumps, farms, ranches, and one small reservation town. The population centers within the Cooperative's area are served by the Montana Power Company, an investor-owned utility. 


\subsection{Project Description}

The proposed Wild Horse line is a $69-\mathrm{kV}$ overhead electric transmission line, approximately 17 to 22 miles in length, depending on routing. It would be located in northern Montana, just north of Gildford, Montana, and continue to the Canadian border.

The proposed 69-kV Wild Horse transmission line would tap at or near the North Gildford Substation, then extend north to the Canadian border. Several alternate routes have been considered and are summarized in Section 2 Hill County Co-op would own, operate, and maintain the facilities to be constructed on the U.S. side of the international border, and TCP would own, operate, and maintain the transmission facilities to be constructed in Canada.

The line would be a radial circuit constructed as a single wood pole overhead transmission line designed in accordance with Rural Utilities Service (RUS) guidelines. The circuit would be operated at a nominal 69,000 volts (line to line) and 60 hertz. Phase conductors would be 4/0 6/1 ACSR (Penguin). One conductor per phase would be used. The transmission line will be constructed with a $3 / 8$ " high-strength steel overhead static conductor (for lightning diversion). The transmission line will be designed to the National Electrical Safety Code (NESC) heavy loading parameters of one-half inch ice and a four pound wind load. All NESC vertical and horizontal clearances would be met or exceeded.

The primary structure would use a TP-69G arrangement with horizontal post insulators (see Figure 1-2). There would be approximately sixteen wooden pole structures per mile with the average distance between structures of 320 feet. Conductor spacing for this pole would be four feet horizontally and five feet vertically, for a total spacing between phases of 6.4 feet. The static conductor and the top phase have a horizontal separation of two feet and a vertical separation of six feet, for a total spacing of 6.3 feet.

With the TP-69G structure, the transmission design would meet the following line-to-ground clearances:

$\begin{array}{ll}\text { Cultivated fields } & 22 \text { feet } \\ \text { County roads } & 25 \text { feet } \\ \text { State highways } & 30 \text { feet }\end{array}$

The maximum span anticipated would be at the Milk River crossing, which requires a 1,200foot span. Hill County would install TH-5GD structures to allow better conductor separation on this crossing. TH-5GD structures, shown in Figure 1-3, are three wooden poles supporting a cross-arm from which the conductors hang. This structure causes the three conductors to occupy one horizontal plane.

The permanent minimum right-of-way for the transmission line would be 20 feet. Another 20-foot temporary easement will be needed during construction. Horizontal clearance to all existing structures (i.e., buildings, grain bins, etc.) would be 60 feet. 


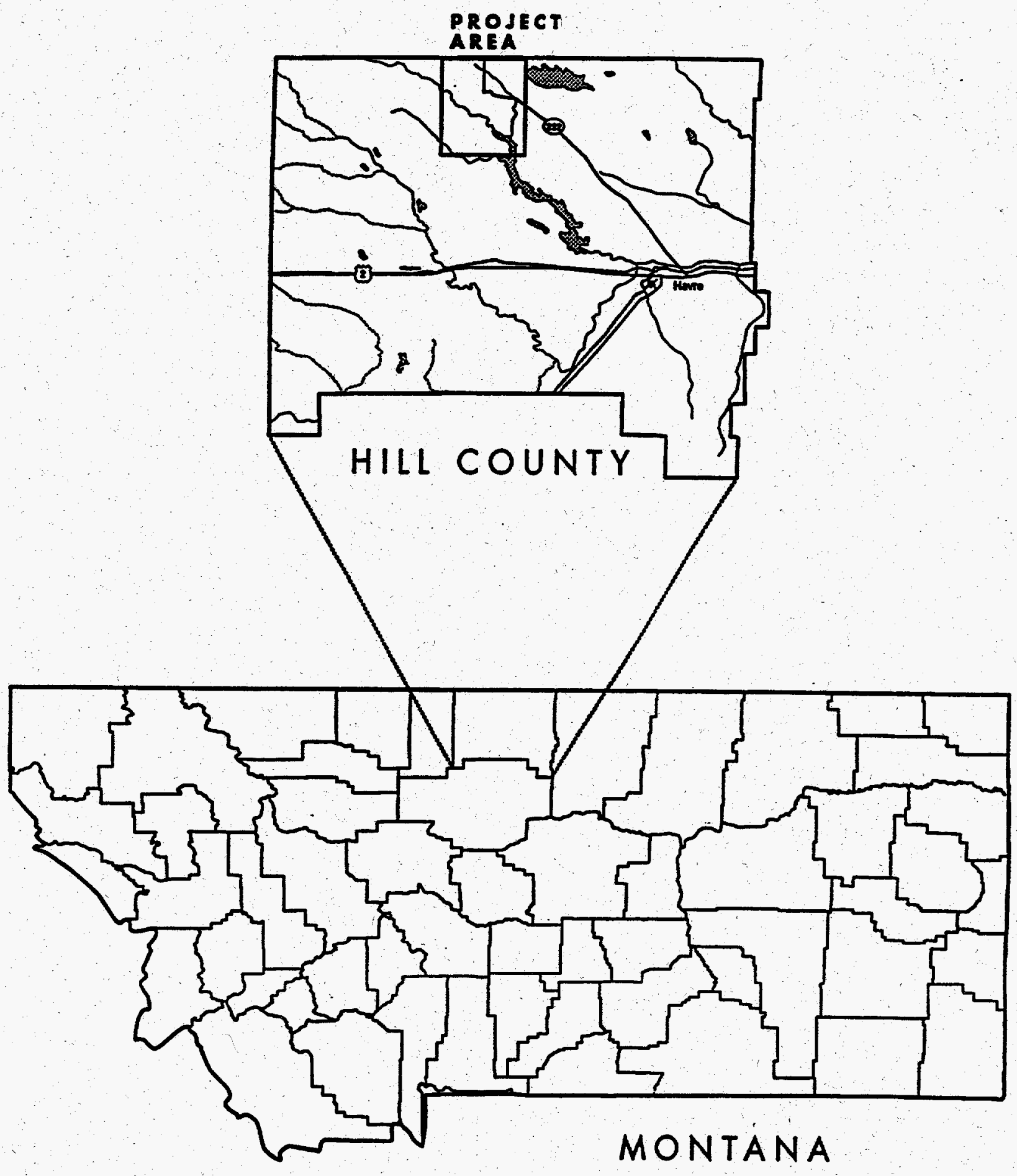

FIGURE 1-1

Vicinity Project Area Map 

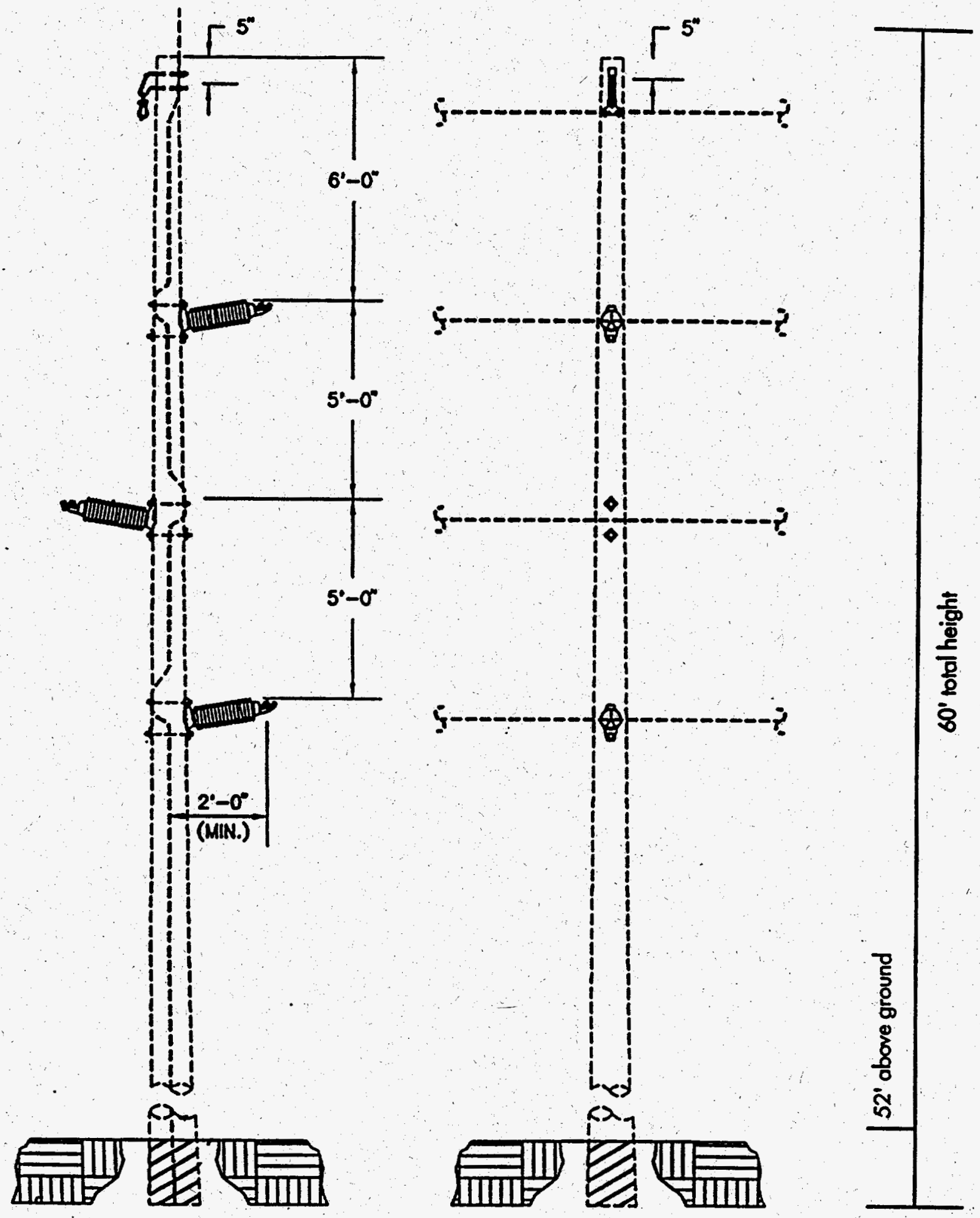

FIGURE 1-2

TP-69G Transmission Line Pole 


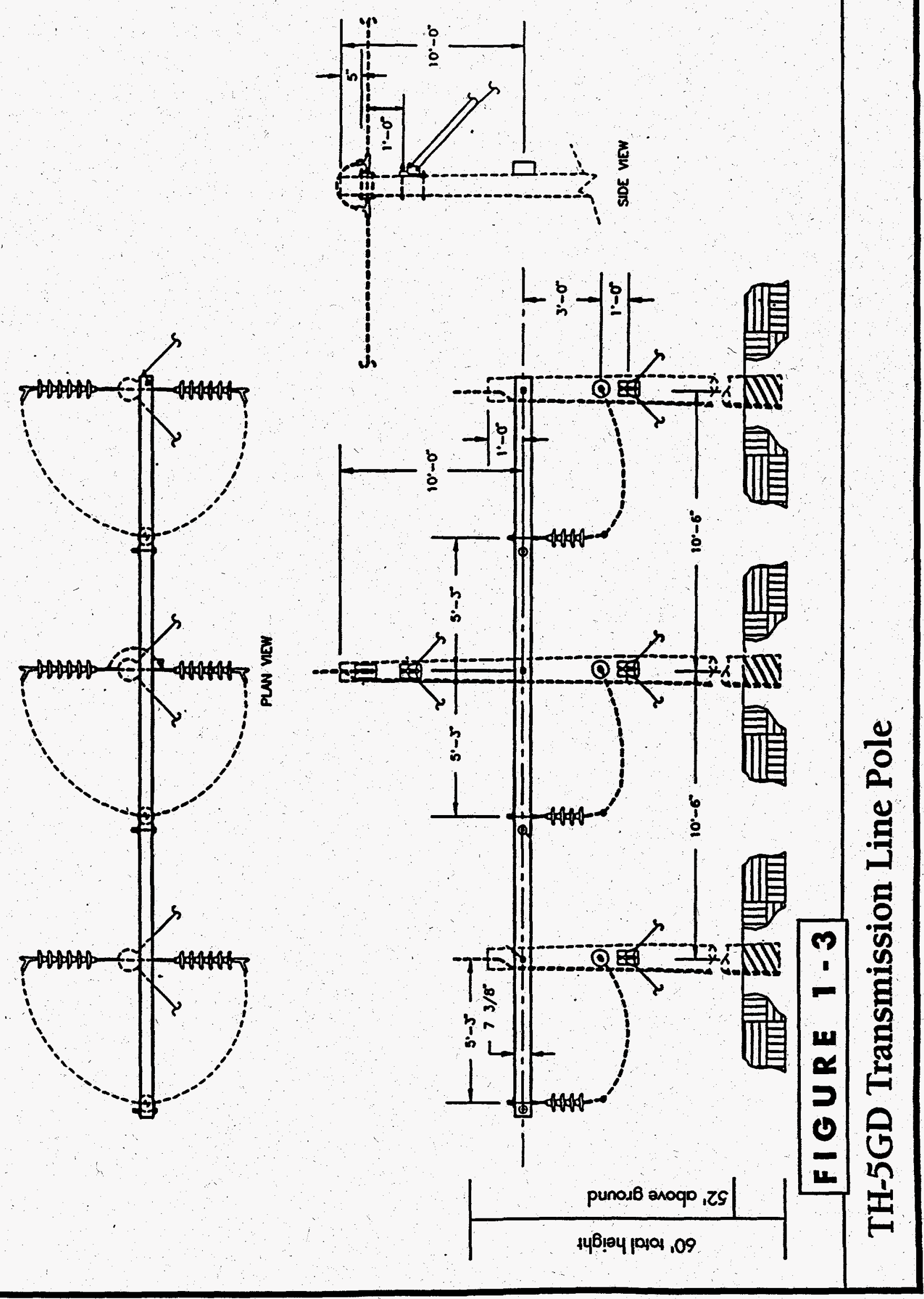


Hill County has a $69-\mathrm{kV}$ point of delivery with Western Area Power Administration (WAPA) at Rudyard, Montana. The Rudyard 115/69-kV Substation is owned and operated by WAPA and taps the WAPA 115-kV circuit between the towns of Havre and Shelby. This substation is comprised of single phase transformers that have the capability of carrying the current load, as well as the proposed Express Wild Horse station at the initial and intermediate configurations. A single pole $69-\mathrm{kV}$ transmission line owned by Hill County currently extends $\mathbf{2 1 . 5}$ miles to the north from the Rudyard Substation, before branching east and west. The western branch of the transmission line extends west 12 miles to the Goldstone and North Joplin Substations. The eastern branch of Hill County's existing 69-kV transmission line proceeds east to the North Gildford Substation and continues for 22.1 miles to the North Havre Substation.

The Express Pipeline would be operated at a maximum flow rate of approximately 170,000 barrels per day (bpd). It is expected that this configuration and would result in the following electrical consumption at the Wild Horse pumping station, and resultant electrical demand on Hill County: approximate maximum $5,000 \mathrm{~kW}$; approximate minimum 2,000 kW; and approximate average $3,000 \mathrm{~kW}$.

\subsection{Required Permits/Approvals}

In addition to the DOE, the following federal, state, and local government agencies have some type of jurisdiction over the action to be taken or are commenting agencies to the EA. Correspondence with these agencies and approvals granted to date are included as Appendix D.

\section{International}

\subsubsection{Intemational Boundary Commission \\ United States and Canada \\ 615 Booth Street \\ Ottawa, Ontario K1A OE9}

Section 5 of the International Boundary Act requires approval to "construct, operate and Maintain" facilities across the U.S. and Canadian International Boundary by the International Boundary Commission. Application was filed on September 23, 1996, and approval is pending. 


\section{Federal}

\subsubsection{Rural Utilities Service (RUS)}

14th \& Independence Avenue, SW

Washington, DC 20250

The RUS, formerly the Rural Electrification Administration (REA), oversees the activities of rural electric cooperatives pursuant to the Rural Electrification Act of 1936, as amended. Hill County is a rural electric cooperative. RUS is participating in the NEPA review process.

\subsubsection{U.S. Bureau of Reclamation (BOR) Montana Area Office \\ P. O. Box 30137 \\ Billings, MT 59107}

Federally-owned lands managed by the BOR will be crossed by the proposed transmission facility. Hill County has filed an application with the BOR for a right-of-way and/or crossing permit; this approval is pending.

\subsubsection{U.S. Army Corps of Engineers (COE) \\ 301 S. Park, \#10014, Room 246 \\ Helena, MT 59626-0014}

The proposed transmission facility will cross the Milk. River. The COE has jurisdiction over any dredge and fill of waters of the U.S., pursuant to Section 404 of the clean Water Act. The COE has issued a ruling of "no permit required" since no construction activities would take place and no fill would be placed in the waters of the U.S.

\subsubsection{U.S. Fish \& Wildlife Seroice (FWS) \\ 100 North Park Avenue, Suite 320 \\ Helena, MT 59601}

The FWS is responsible for overseeing and protecting all endangered and threatened botanical and biological species in the U.S. No endangered or threatened species are potentially affected by the proposed facility based on field surveys. The FWS will address mitigation conditions such as structure design to reduce raptor electrocution, installation of avian avoidance markers at river crossings, and other wildlife protection measures. The FWS was sent a letter summarizing the field surveys and recommending that impacts to plants and wildlife were less than significant. FWS's response is pending. 


\subsubsection{Western Area Power Administration (WAPA)}

P. O. Box 35800

2900. Fourth Avenue

Billings, MT 59101-1266

WAPA is a power marketing agency that sells and transmits power generated by federal dams to preferred customers, including Hill County. WAPA has an interest in the effect on system reliability of the proposed export and the construction and operation of the proposed transmission facilities as they interconnect with the WAPA-operated transmission system.

\subsubsection{U.S. Natural Resounces Conseroation Seroice (NRCS)}

720 First Street West

Havre, MT 59501

The NRCS, formerly known as the Soil Conservation Service, is charged with the conservation of "important farm lands." It administers the Conservation Reserve Program (CRP) in coordination with the U.S. Department of Agriculture, Farm Service Agency (FSA). The NRCS has issued a permit indicating no prime, unique, statewide or local farmland will be impacted by the project.

\subsubsection{U.S. Bureau of Land Management (BLM)}

P. O. Box 119

Worland, WY 82401

The proposed transmission line does not cross any BLM-owned lands; however, the BLM was the lead federal NEPA agency on the Express Pipeline. The EIS prepared for the BLM on the Express Pipeline is incorporated by reference to this EA. The BLM is a commenting federal agency to the DOE.

\section{State}

\subsubsection{Montana State Land Board (SLB)}

\section{1 th Avenue}

Helena, MT 59620

The SLB grants easements for any construction on state-owned land, and issue permits for navigable rivers. The Department of Natural Resources and Conservation (a department of the SLB) indicates the Milk River is not a navigable river. No state lands would be crossed and no further approval from SLB is needed. 


\subsubsection{State Historic Preseroation Office (SHPO) \\ Montana Historical Society \\ P. O. Box 201202 \\ 1410 8th Avenue \\ Helena, MT 59620-1202}

A report on historic or archaeologically significant locations potentially impacted by the proposed transmission facility has been prepared for submission to the SHPO. SHPO's approval is pending. Mitigation will likely be required.

\subsubsection{Montana Department of Environmental Quality (DEQ) \\ 120 East 6th Avenue \\ Helena, MT 59620}

The DEQ has both siting and environmental quality jurisdiction over facilities constructed in Montana. Transmission lines at or below $69-\mathrm{kV}$ are not, however, subject to DEQ siting review. However, in its action on the Express Pipeline, the DEQ included a description of the Wild Horse $69-\mathrm{kV}$ transmission line as an auxiliary facility, and has approved the proposed line as part of its decision for Express Pipeline.

\subsubsection{Montana Department of Fish, Wildlife \& Parks (FWP) 1400 South 19th Street Helena, MT 59715}

FWP is a commenting agency to the DOE's EA. The FWP was sent a letter stating impacts to plants and wildlife were less than significant and ask them to reply within 30 days if they were not agreement with the finds. FWP has not replied.

\section{Local}

\subsubsection{Hill County Conseroation District 20625 th Avenue West Havre, Montana 59501}

The Hill County Conservation District reviews the 310 Application, State of Montana Natural Streambed and Land Preservation Act, application for the State of Montana. Applicants are required to submit a description for all crossings of perennial streams to insure appropriate measures are taken to preserve natural streambeds. The Conservation District has issued the 310 Permit with the ruling of "not a project." 


\subsubsection{Hill County Weed Department \\ Courthouse \\ Havre, Montana 59501}

The Hill County Weed Department administers the Noxious Weed Management Act to insure the spread of weeds does not occur from project actions. The construction of the transmission line will follow Department requirements.

\subsection{Canadian Regulatory Actions}

The Wild Horse pumping station is located seven miles north of the Canadian border and one mile west of the highway running south to the United States. The total length of the transmission line in Canada will be approximately 9.5 miles, crossing the border at the Wild Horse port-of-entry and following the highway on the eastern side to a point exactly one mile east of the pumping station. At this point, it will cross the highway to the pumping station. Hill County and TCP have coordinated their environmental review activities with the regulatory agencies on both sides of the U.S.-Canadian border.

Environmental oversight for the Canadian portion of the border is being provided by the National Energy Board of Canada (NEB). Any environmental impacts will be addressed by the NEB under Canadian environmental requirements. An environmental assessment has been prepared for the NEB to address the affected environment and potential impacts; as well as mitigation measures to be taken in the construction, maintenance, and operation of the 69-kV transmission line in Canada. An application has been filed with the NEB for a certificate authorizing construction and operation of the transmission line.

Originally, and under the No Action Alternative, diesel engines were to be used to power the pumping station. Use of diesel engines would impact air quality in the Canadian portion of the local area immediately surrounding the station. Other impacts associated with the Canadian portion of the transmission line would be to aesthetics in the local area and potential impacts to waterfowl at Milk River Lake. These latter impacts would be mitigated with line spacing and marking in accordance with requests from the NEB and provincial agencies. Mitigation measures on the U.S. and Canadian sides of the border would be compatible. 
Along with the Proposed Action, several alternatives were considered, including no action, two routing alternatives, and an alternate construction method. Alternative routes are shown in Figure 2-1.

\section{$2.1 \quad$ No Action}

Under this alternative, Hill County would not build an electric transmission line and the Express Wild Horse pumping station would be powered by diesel generators at the site. The design of the pumping station would be reengineered, and diesel engines would be ordered and installed. The plant would be rewired and repiped and a delay of several months would result. The estimated additional cost for the diesel engines is $\$ 3$ to 5 million.

If the Wild Horse pumping station is not built on schedule with electric pumps, versus the electric engines, pipeline capacity would be reduced 20 percent overall, until the diesel units were installed at the station. This would amount to a probable delay of six months or more.

\subsection{Proposed Action - Express Route Alternative}

The Proposed Action is to issue a Presidential Permit that would allow Hill County to build a 69-kV electric transmission line in Montana along the Express Route to export electricity to TCP. TCP, a Canadian power-marketing company, would construct a $69-\mathrm{kV}$ transmission line from the international border crossing to the Express Pipeline oil pumping station at Wild Horse, Alberta.

\subsubsection{Route Description}

The Proposed Action is a 17-mile long transmission line which will parallel existing roads and two-track trails nearly its entire length to the Canadian border at the Port of Wild Horse. The line will cross the Milk River at the Express Pipeline right-of-way (see Figure 2-1). This route was designed to reduce impacts to the environment by maximizing the use of the Express Pipeline right-of-way and to minimize impacts to cultural and biological resources. This route is the most advantageous, considering environmental, economic, and engineering considerations.

The route will begin at the Gildford Substation, located in the northwest corner of Section 10 (T35N,E11E). The first six miles of the transmission line will parallel county roads and an existing Hill County $12-\mathrm{kV}$ distribution line through an agricultural area currently planted in wheat. 


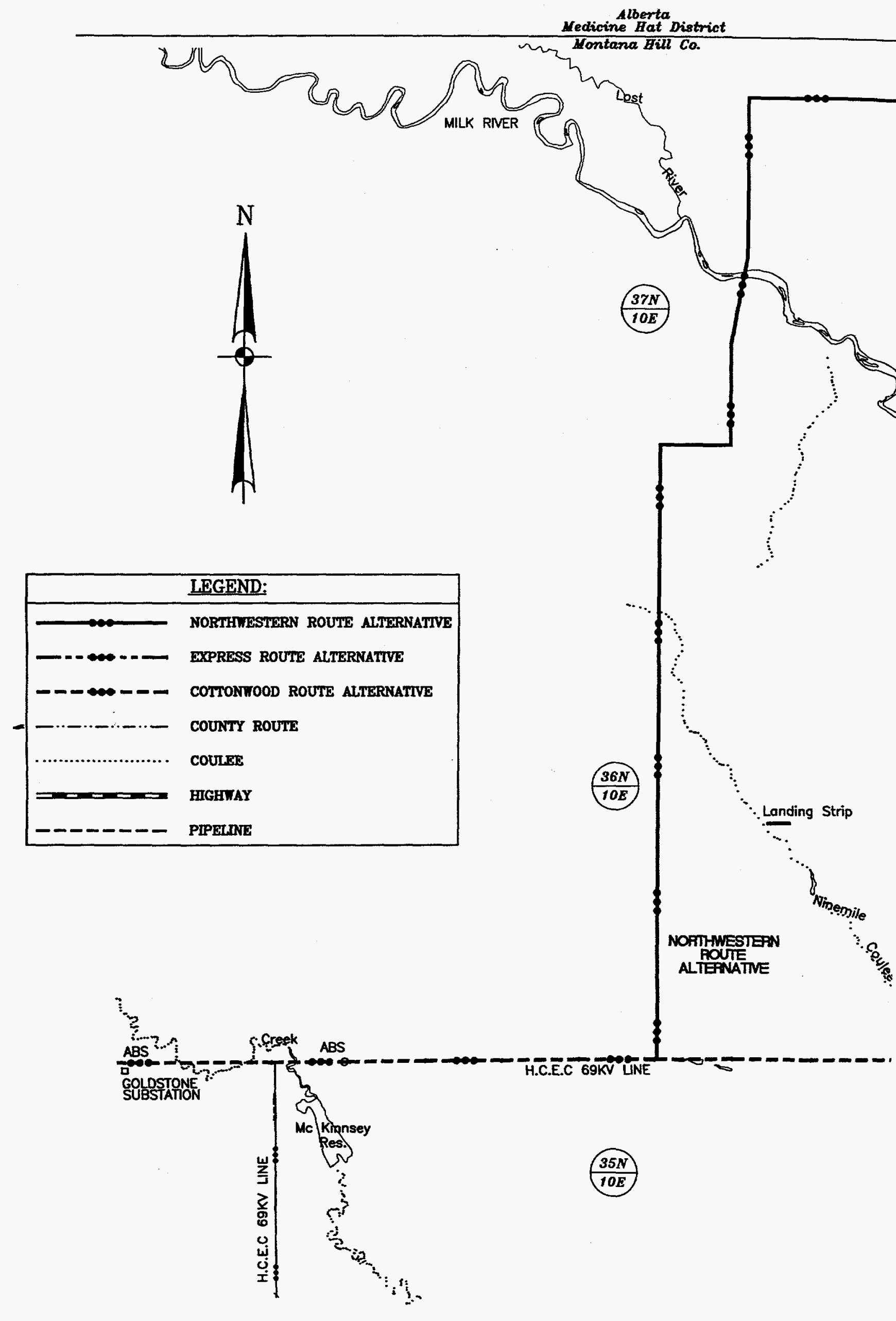


The line will cross the Milk River east of the Express Pipeline in Section 13 (T36N,R11E), and would continue down the south bluff and onto the Milk River floodplain, crossing over a low island in the floodplain, and then spanning the river. Immediately north of the Milk River crossing, the electric transmission line would run northeast and climb out of the floodplain on an existing two-track road in Section 12 (T36N,R11E).

After leaving the Milk River, the route follows dirt roads and section lines for two miles, and then turns east for one mile to Highway 232. At Highway 232 the line follows the highway north for five miles to the Canadian border. The surrounding fields are planted in wheat or are fields which are in the Conservation Reserve Program (CRP).

Construction of the transmission line will begin in the fall of 1996, following regulatory approvals. There are no significant construction impediments with this route and most construction will take place from existing roads and two-track trails. Access roads built for the Express Pipeline on both the north and south side of the Milk River will provide construction access for Hill County. The transmission line was designed for a single pole, horizontal post style of construction, as described in Appendix E. Most of the conductors along the route will be strung using the back-string and lay-up method. However, along the Milk River, a tension drum is used to pull rope which is attached to the conductor. The conductor is pulled through traveller which maintain tension in the conductor. This prevents the conductor from contacting the terrain, water, or other obstacles.

The line will be built with TP -69 single, wooden pole structures. A three-pole structure design, the TH5-HG, will be used to cross the Milk River. TP-69 poles will be placed approximately 350 feet apart and TH5-HG poles will be placed approximately 1,200 feet apart. The permanent right-of-way will be 20 feet, with another 20 -foot temporary construction easement. The estimated construction costs for this proposed alternative are shown in Table 2-1. A short 7.2-kV transmission line feed will be built to provide electrical service to an electrically operated emergency pipeline valve on the Express. Pipeline north of the Milk River.

There would be a voltage drop from $120-\mathrm{V}$ (base) to $114.5-\mathrm{V}$ on this alternative, or an 8.7 percent drop in voltage due to line length. This drop is within the 10 percent standard for reliability.

\subsubsection{North Gilford Substation Additions}

Hill County has a small distribution substation located on a one-acre lot at North Gildford. Hill County is proposing to expand the existing eight foot high substation perimeter fence. The fence expansion would cover an area 85 feet by 75 feet $(0.15$ acres).

The ability to switch or isolate the 69-kV transmission line east and north of the Gildford substation will be added. Three air-break switches; a $69-\mathrm{kV}$ bus arrangement and three 
deadend structures for the $69-\mathrm{kV}$ line would be installed at the substation. Figure $2-2$ shows the proposed substation addition in relation to the proposed Express route alternative.

The proposed Gildford switch station will allow Hill County to sectionalize (electrically isolate or deenergize) the north circuit (Wild Horse) from the east circuit (North Havre) and vice-versa. If a fault develops on the North Havre line, power can be maintained to Wild Horse. The same applies for North Havre if a fault occurs on the Wild Horse line. This increases reliability of service to the North Gildford, Wild Horse and North Havre substations by giving Hill County the ability to selectively isolate any of these stations. Maintenance or fault repairs can be performed on any section without disrupting service to the other taps.

\subsubsection{Applicant's Proposed Mitigation Measures}

The following mitigation measures will be implemented for construction and operation of the transmission line:

1. Dust control measures (e.g, compaction, watering) will be implemented in accordance with the requirements of the Montana DEQ Air Quality Bureau.

2. The Preliminary Restoration Plan contained in the Express Pipeline Draft EIS will be followed to control erosion.

3. At the Milk River crossing, three TH5-HG poles will be used at each pole placement area. This will position the conductors on one, horizontal plane parallel to the ground, reducing the potential strike area to waterfowl and raptors.

4. The strike area will be further reduced by removal of the shield wire for the portion of the transmission line spanning the Milk River. Studies show the removal of this wire will reduce bird strikes by up to 50 percent. The shield wire will be removed from bluff to bluff across the Milk River,

5. Bright yellow helical wrap will be used at the Milk River crossing to increase the transmission line visibility to waterfowl and raptors. (The shield wire will also be removed from the Cottonwood crossing and bright yellow helical wrap will be added to the conductor at the Cottonwood crossing.) At the river crossing portion, the helical wrap will alternate 25 feet each phase.

6. The transmission line will only be placed on property where landowner approval has been received.

7. Devices to discourage raptors from perching on poles will be placed on the poles at the Milk River. Examples of such devices include spikes or triangles placed on the top of the pole. 
Table 2-1

Wild Horse Transmission Line Alternatives

Length, Features and Construction Cost Summary

\begin{tabular}{|l|r|r|r|}
\hline \multicolumn{1}{|c}{ Route } & \multicolumn{1}{c|}{$\begin{array}{c}\text { Distance } \\
\text { Miles }\end{array}$} & \multicolumn{1}{c|}{$\begin{array}{c}\text { \$(000)/ } \\
\text { Mile }\end{array}$} & \multicolumn{1}{c|}{$\$(\mathbf{0 0 0})$} \\
\hline 1. Express Route Alternative & \multicolumn{3}{|c|}{} \\
\hline a. New 69-kV Gildford to Border & 17.0 & $\$ 75.0$ & $\$ 1,275.0$ \\
\hline b. New 7.2-kV Feeder Line to Express Valve & 1.0 & $\$ 15.0$ & $\$ 15.0$ \\
\hline
\end{tabular}

2. Northwestern Route Alternative

\begin{tabular}{|l|r|r|r|}
\hline a. New 69-kV 5mi W of Gildford to Border & 18.5 & $\$ 75.0$ & $\$ 1,387.5$ \\
\hline b. New 69-kV River Crossing & 3.5 & $\$ 106.4$ & $\$ 372.4$ \\
\hline c. New 7.2-kV Feeder Line to Express Valve & 1.6 & $\$ 15.0$ & $\$ 24.0$ \\
\hline
\end{tabular}

\begin{tabular}{|l|r|r|r|}
\hline \multicolumn{1}{|c|}{ 3. Cottonwood Route Alternative } & \multicolumn{3}{|c|}{} \\
\hline a. New 69-kV Gildford to River & 10.0 & $\$ 75.0$ & $\$ 750.0$ \\
\hline b. Retire 69-kV Gildford to River & 10.0 & $\$ 2.5$ & $\$ 25.0$ \\
\hline c. New 69-kV River to Border & 19.5 & $\$ 75.0$ & $\$ 1,462.5$ \\
\hline d. New 7.2-kV Feeder Line to Express Valve & 1.6 & $\$ 15.0$ & $\$ 24.0$ \\
\hline
\end{tabular}




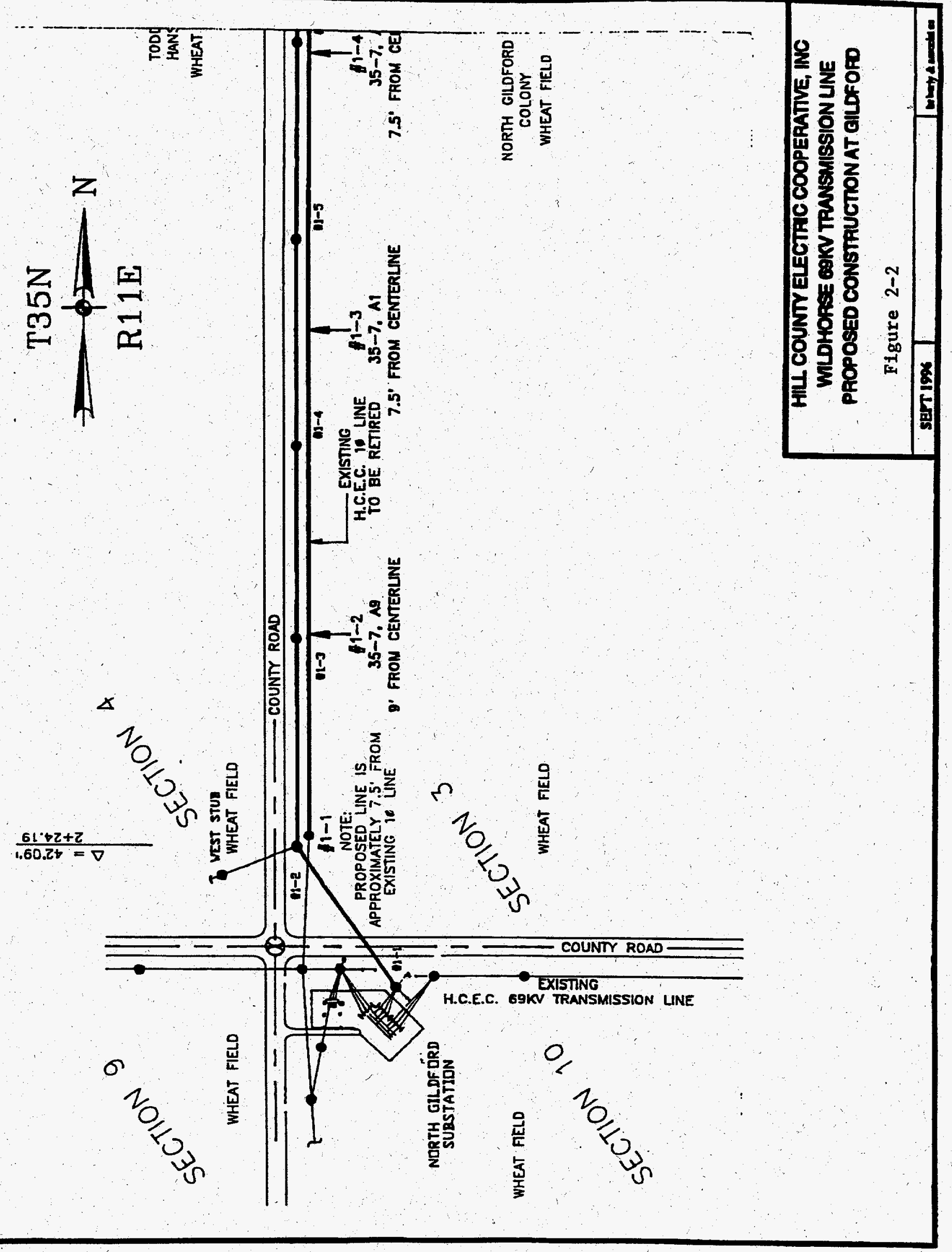


8. Perching poles will be placed away from the transmission line on either side of the Milk River for raptor use.

9. Construction activity will be timed to avoid the raptor breeding season.

A. Waterfowl surveys will be conducted over a two year period. Radar will not be used as, in general, radar surveys are used for large migratory flocks in open spaces. This is not a known heavy migratory corridor and use of radar in areas surrounded by bluffs can be problematic due to radar reflection off the bluffs. Instead, wildlife biologists will conduct in-person counts according to protocols acceptable to US Fish and Wildlife Service (USFWS) and Montana Department of Fish, Wildlife \& Parks (MDFWP);

B. Poles that are demonstrated to cause excessive raptor electrocution due to inadequate raptor mitigation design will be replaced or modified over a 10year period; and

C. If waterfowl surveys indicate that this new line is contributing to unacceptable levels of waterfowl mortality, then the applicant will discuss with USFWS and MDFWP what additional mitigation may be applied.

10. No construction in wetlands or streams will take place.

11. Sites of known cultural resources will be avoided. Further visual impacts to a "medicine wheel" site (Site \#795) on the north bank of the Milk River will be mitigated by constructing the line at the crossing, east and south of the site, and then through coulees and areas not visible from the cultural site.

12. Construction workers will be instructed about cultural sites and types of fossils they could encounter, and the steps to be taken if they uncover fossils anywhere during construction.

13. An archaeologist will be on-site during construction at the Milk River to monitor activities around cultural sites.

14. A paleontologist will be on-site during construction to monitor activities on the Milk River which may affect paleontological resources.

15. Any fossil specimens recovered during construction monitoring will be curated into the collection of a museum repository acceptable to the USBOR:

16. A final technical paleontological report will be prepared and submitted following completion of construction. 
17. An insulation paint at $2100 \mathrm{~V} / \mathrm{mils}$ will be used on insulator bases and bolts on the HG-69 structures.

18. The guywires at the river crossing structures will be wrapped with bright yellow helical wrap.

\subsection{Northwestern Route Alternative}

\subsubsection{Route Description}

The Northwestern Route Alternative would begin five miles west of the Gildford Substation and parallel county roads and section line trails for 20 of its 22-mile length north to the Canadian border crossing. Except for CRP-reserved and undisturbed grazing lands at the Milk River crossing, the route is through active farm land planted in wheat. This route was designed to be close to the Rudyard Substation to increase line reliability. It was considered because of its higher reliability.

Construction of the Northwestern Route Alternative would be more difficult at the Milk River than the Express Route Alternative, and access to the crossing may need to be upgraded from current two tracks on both the north and south side of the Milk River. Construction of the transmission line would not encounter serious problems.

The same poles and span distances would be used as in the Express Route Alternative. Also, a short 7.2-kV electric line feed would be built from the $69-\mathrm{kV}$ line to an emergency shut off valve on the Express Pipeline north of the river.

Estimated construction costs are shown in Table 2-1. There would be a voltage drop from $120-\mathrm{V}$ (base) to $115.9-\mathrm{V}$ on this alternative, or an 8.1 percent drop in voltage due to line length. This drop is within the 10 percent standard for reliability.

\subsubsection{Applicant's Proposed Mitigation Measures}

The same mitigation measures would be implemented for construction and operation of the Northwestern Route Alternative as for the Express Route Alternative, including for the future upgrade.

\subsection{Cottonwood Route Alternative}

\subsubsection{Route Description}

The Cottonwood Route Alternative would involve upgrading an already existing 69-kV line from the Gildford Substation east to the Milk River next to the highway bridge on the north end of the Fresno Reservoir (the Cottonwood Bridge). After crossing the Milk River, a new 69-kV line will be constructed north to Highway 232. It will then follow Highway 232 north to the Canadian border. The Cottonwood Alternative is 19.5 miles long. 
This route was developed to utilize an existing crossing at the Milk River, thereby preventing the addition of a new crossing. This route was also considered in order to potentially reduce impacts to waterfowl by eliminating a new, second crossing of the river (at either the Express or Northwest Alternative locations).

Access across the Milk River would be at the current crossing, along the Cottonwood Bridge. After crossing the bridge at the Milk River, the transmission line will follow country roads and the highway. No significant access nor construction engineering problems are anticipated.

The same poles and span distances would be used as in the Express and Northwestern Route Alternatives.

The Cottonwood Route Alternative taps the existing $69-\mathrm{kV}$ line towards the end of the current transmission line; thus more upgrading is needed and voltage losses are greater than the other two proposed routes. In addition to the construction of the new transmission line, the Cottonwood Route Alternative will require the upgrading of 10 miles of line from the Gildford Substation to the Milk River at the same time as the present poles, conductor, and insulators would be removed.

Table 2-1 shows the costs and specifics for this alternative. Because of the additional length of this alternate, there would be a drop in voltage from $120-\mathrm{V}$ (base) to $111.4 \mathrm{~V}$ on the line. This 11.6 percent voltage drop exceeds the 10 percent maximum standard for reliability.

\subsubsection{Applicant's Proposed Mitigation Measures}

The same mitigation measures would be implemented for construction and operation of the Cottonwood Route Alternative and its future upgrades as with the other two alternatives. 



\subsection{Proposed Express Route Alternative}

\subsubsection{Air Quality}

Air quality in the Hill County area is characterized by an absence of major stationary sources combined with relatively flat terrain and frequent winds. Average wind velocities in the project area would vary between 10 to 15 miles per hour during the proposed period of construction, with a maximum of approximately 30 miles per hour. Fugitive emissions (dust) from unpaved roads and farmland along with smoke resulting from the seasonal burning of agricultural waste (wheat stubble) are the most notable forms of air pollution.

Ambient monitoring data for Hill County is not available. ${ }^{1}$ Therefore, the county is assumed to be designated as unclassified (attainment by default) with respect to both the federal and Montana Ambient Air Quality Standards (AAQS). ${ }^{2}$

\subsubsection{Geology and Soils}

The transmission route is located in the section of the Missouri Plateau known as the Great Plain Physiographic Province. This section is characterized by flat to hummocky glacial till and local patches of outwash gravels and lake sand, silt, and clay which overlies mostly Cretaceous shale (BLM 1975). Streams have created wide, shallow valleys into the plateau, especially along the Milk River.

The route does not cross any major seismic areas and is not in areas where landslides have occurred.

Soils in this area consist of deep, well-drained, fine loamy to clayey textured soils. Topsoil depth ranges from 6 to 12 inches.

1 Per the Montana Department of Health and Environmental Sciences, Air Quality Bureau, there has been no ambient monitoring in the Hill County area in the last 15 years. Any monitoring performed previously would have been for TSP rather than $\mathrm{PM}_{30}$ and would not have included any gaseous pollutants (personal communication with R. Jeffery, June 26, 1996).

2 For the most part Montana's AAQS parallel the federal standards. Notable differences include: sulfur dioxide - Montana applies a one hour averaging time for the $50 \mathrm{ppm}$ standard as opposed to the federal 3 hour averaging time and the Montana 24 hour and annual average standards are .10 ppm and $.02 \mathrm{ppm}$, respectively (compared to the federal levels of .14 ppm and .03 ppm); ozone-Montana uses a $.10 \mathrm{ppm}$ (hourly average) standard rather than the federal $.12 \mathrm{ppm}$; nitrogen dioxide Montana annual average standard of $0.5 \mathrm{ppm}$ is more stringent than the federal standard of .053 Ppm; carbon monoxide - the Montana hourly standard is 23 ppm versus the federal standard of 35 ppm; lead - both the Montana and federal standards are $1.5 \mu \mathrm{g} / \mathrm{m}^{3}$, but Montana applies a quarterly (annual) averaging time, while the federal standard uses a 90 day averaging period. 


\subsubsection{Surface Water and Floodplains}

The project area is crossed by the Milk River. The active flood plain extends from about 700 feet north of the north bank to about 600 feet south of the south bank and the width of the Milk River at the crossing is 150 feet. The Milk River has relatively more sediment compared to rivers in western Montana because of sediment and dissolved solids from drained croplands and from run-off from the badlands.

The upstream end of a small agricultural impoundment will be spanned by the Express Route Alternative. It is located at the corners of Sections 22, 23, 26, and 27 (T36N,R11E). The surface water of the impoundment is approximately 60 feet wide at the proposed crossing and extends easterly towards the Milk River.

Vegetation present is typical of ponds. Dominant species include bluegrass (Poa palustris), Nebraska sedge (Carex nebrascensis), amphibious sorrel (Rumex amphibium), Baltic rush (Juncus balticus), and Great Plains cottonwood (Populus deltoides).

Lands surrounding the pond are planted in wheat. These lands did not appear to have been recently grazed. Waterfowl, including mallards, killdeer, double-crested cormorants, and gadwall, were observed in the wetland. Deer tracks were observed along the edges of the wetland.

Dry coulees, intermittent streams, and standing water in roadside ditches are also located along the Express Route Alternative.

\subsubsection{Wetlands}

Scattered wetland riparian vegetation is located east of the Express Route Alternative and the agricultural impoundment in Sections 22, 23, 26, and 27 (T36N,R11E). Dominant species include bluegrass (Poa palustris), Nebraska sedge (Carex nebrascensis), amphibious sorrel (Rumex amhibium), and Baltic rush (Juncus balticus). Appendix A shows the location of these wetland features. The right-of-way would cross approximately 0.06 acre of the approximately 34 acres of agricultural impoundment.

\subsubsection{Aquatic Ecology}

The Milk River is classified as a Class IV stream by the Montana Department of Fish, Wildlife, and Parks. This is a stream with moderate fishing resources, the lowest classification. The river also has a Montana Water Classification of B-3. It is suitable for drinking, culinary and food processing purposes after conventional treatment, as well as for agricultural and industrial water supply. It is also suitable for bathing, swimming, recreation, growth, and propagation of non-salmonid fishes and associated aquatic life, waterfowl, and furbearers.

In general, the Milk River is characterized by relatively slow flows and high turbidity. Drainage from croplands and badlands contributes to a comparatively high level of 
sedimentation. Fish found in the Milk River include walleye, sauger, northern pike, channel catfish, and native non-game fish.

\subsubsection{Vegetation}

The plant communities that occur along the Express Route Alternative occur within a landscape that has been transformed largely by agriculture. Much of the land is used for growing wheat; however, there are remnants of native perennial grassland, ponds and prairie wetlands. There are no trees along the Express Route Alternative, other than two cottonwoods at the Milk River crossing.

The FWS and Montana Natural Heritage Program (MNHP) were contacted regarding known and potential occurrences of special-status species in the study area. The FWS did not identify any plant species with potential to occur within the study area (FWS 1996). The MNHP identified threelobed beggarticks (Bidens comosa) and desert groundsel (Senecio eremophilus var. eremophilus) as potentially occurring in the study area (MNHP 1996). Both of these species are state-ranked 1 (critically imperiled because of extreme rarity [5 or fewer occurrences or very few remaining individuals] or because of some factor of its biology making it especially vulnerable to extinction). Big sagebrush/rough fescue habitat type was also identified by MNHP as potentially occurring in the study area.

A review of the studies conducted for the Express. Pipeline project was performed. The Express Pipeline Draft Environmental Impact Statement (BLM 1995) revealed no specialstatus plant species identified in the Express Pipeline right-of-way from milepost zero to milepost 20.

The proposed alignment was surveyed for special-status species and their habitats on June 30 and July 1, 1996. Surveys were conducted within a 40-foot corridor on foot and by vehicle. All species observed were recorded. Survey results are included as Appendix B.

Threelobed beggarticks and desert groundsel were not encountered. The closest known locations of these species are in Beaver Creek County Park, approximately 60 miles south of the study area. The big sagebrush/rough fescue habitat type does not occur in the project area. The nearest known location is south of Beaver Creek County Park, approximately 60 miles south of the study area.

Five habitat types were encountered along the proposed alignment. No special-status species or their habitats were encountered. Appendix B lists the species encountered.

Roadsides and wasteplaces: This plant community occurs along roadsides and between wheat fields. This community is located throughout the proposed alignment. Dominant species of waste places and disturbed roadsides include crested wheatgrass (Agropyron cristata), smooth brome (Bromus inermis), and kochia (Kochia scoparia). 
Hedgerows: The dominant species of hedgerows include two shrub species that reach a height of about five to eight meters: Siberian pea (Caragana arborescens) and Russian olive (Elaegnus angustifolia). The hedgerows are located primarily in Section 4 (T35N,R11E) and Sections 26, 27, and 34 (T36N,R11E).

Native perennial grassland: Remnants of native perennial grassland occur along the proposed route along the tops of the north and south bluffs of the Milk River. These remnants are located at Sections 1, 12, and 23 (T36N,R11E). Dominant species included fringed sage (Artemisia frigida), blue grama (Bouteloua gracilis), and needle and thread grass (Stipa comata).

Fallow cultioated pasture: This is land that has been planted but left unharvested. The dominant species include crested wheatgrass (Agropyron cristatum), smooth brome (Bromus inermis), and alfalfa (Medicago sativa).

Exposed clays and coulees: Exposed clays and coulees occur along the bluffs at the Milk River crossing. This habitat is sparsley vegetated with species including Gardner's saltbrush (Atriplex gardneri), saltgrass (Distichlis stricta), and silver sage (Artemisia cana). These species are commonly found in alkali soils. The crossing is located at Sections.11, 12, 13, and 14 (T36N,R11E).

Canada thistle (Cirsium aroense) is a Category 1 (actively and widely spreading noxious weed) on the Montana Noxious Weed list. It occurred along roadsides and in fallow fields along all the proposed powerline routes.

\subsubsection{Wildlife}

The study area is primarily cropland (wheat), with native perennial grasslands used for grazing along the bluffs of the Milk River. Species commonly encountered included western meadowlark (Sturnella neglecta) and horned lark (Eremophila alpestris). Appendix C lists wildlife species encountered.

The FWS and MNHP were contacted regarding known and potential occurrences of specialstatus species in the study area. The FWS identified three listed species with potential to occur within the study area (FWS 1996). These species were the threatened bald eagle (Haliaeetus leucocephalis), and the endangered black footed ferret (Mustela nigripes) and peregrine falcon (Falco peregrinus). The MNHP identified desert shrew (Sorex nanus), stateranked 3, as potentially occurring in the study area (MNHP 1996). Species state-ranked 3 are either very rare and local throughout its range, or found locally (even abundantly at some of its locations) in a restricted range, or vulnerable to extinction throughout its range because of other factors; in the range of 21 to 100 occurrences.

A review of the studies conducted for the Express Pipeline project was performed. The Express Pipeline Draft Environmental Impact Statement revealed mule deer winter range 
along the Milk River (Odocoileus hemionus) (BLM 1995). Raptor studies were performed for the Express Pipeline on May 1, 1996. No raptor nests were located within the right-of-way. However, two ferruginous hawk nests (Buteo regalis) are located in a cottonwood (Populus sp.) in the Milk River basin approximately 1,500 feet east of the Express Pipeline right-ofway during surveys for the Express Pipeline. This nest is located in a coulee adjacent to the transmission line route and about 200 feet west of the line. although reported to be active in spring 1996, subsequent inspections in July through September have not revealed any activity, nor any evidence that the nests have been recently used.

An active prairie falcon (Falco mexicanus) was also located in a clay bank in the Milk River basin approximately 5,000 feet west of the Express Pipeline right-of-way during the Express Pipeline surveys and will be the same distance from the transmission line.

The proposed alignment was surveyed for special-status species and their habitats on June 30 and July 1, 1996 (Appendix C), Surveys were conducted within a 40-foot corridor on foot and by vehicle. All species observed were recorded and no special-status species were encountered.

Potential habitat for bald eagle occurs at the Milk River crossing. Bald eagle breeds on coasts, rivers, and large lakes in open areas, often building nests in the forks of tall trees or on cliffs (Ehrlich et al. 1988). The study area does not provide nesting habitat in tall trees, but cliffs along the Milk River could potentially be used. It is unlikely that bald eagle would nest in the vicinity of the Milk River crossing as it is poor habitat for prey items such as fish, small mammals, and waterfowl. There are no known bald eagle nest sites within one mile of the study area (USFWS 1996) and it is unlikely that this species occurs in the area other than as a seasonal migrant.

Peregrine falcons usually nest on cliffs in open habitats from tundra, savanna, and coastal areas to high mountains and open forests (Ehrlich et al. 1988). The Milk River crossing provides cliffs that may be potential nesting habitat; however, it is unlikely that this species occurs in the area other than as seasonal migrants.

There is no habitat for black footed ferret in the study area. This species is found in prairie dog towns which do not occur in the area.

The closest known location of desert shrew is approximately 70 miles south of the study area on the summit and north slopes of Baldy Mountain, in the Bearpaw Mountains south of Havre, Montana (MNHP 1996).

Hedgerows consisting of crested wheatgrass (Agropyron cristatum), Siberian pea, wavy-leaved thistle (Cirsium undulatum), Russian olive, divergent fleabane (Erigeron divergens), and Great Plains cottonwood (Populus deltoides) provide habitat for numerous small birds and raptors. 
The hedgerows are located in Section 4 (T35N,R11E) and Sections 26, 27, and 34 (T36N,R11E).

Two waterbodies would be crossed by the proposed alignment. The first is at a small agricultural impoundment located at the junctions of Sections 22, 23, 26, and 27 (T36N,R11E). Waterfowl observed in this area include mallard (Anas platyrhynchos), killdeer. (Charadrius oociferus), double-crested cormorant (Phalacrocorax autitus), and gadwall (Anas strepera). Deer (Odocoileus sp.) tracks were observed along this waterbody, but outside of the 40 -foot corridor.

The second crossing is at the Milk River (Sections 11,12, 13 and 14 [T36N,R11E]). This area provides poor quality habitat for waterfowl. There is no standing water in the floodplain and the river edges and sandbars provide little cover for waterfowl. The Milk River is highly turbid and silty. Surrounding uplands consist of alkaline soils with vegetation such as saltgrass (Distichlis stricta).

\subsubsection{Existing and Planned Land Use}

A majority of the land along the proposed pipeline is active farm land, and the most common crop is wheat. No historic or burial grounds are found along the Express Route Alternative. Other than BOR lands, all lands within a half-mile of the Milk River are privately owned. Private lands, all of which are farmed, are traversed by 15.75 miles of the transmission line; 1.25 miles of BOR land would be crossed.

There is a narrow strip of land administered by the International Boundary Commission at the U.S./Canadian border where the transmission line crosses into Canada. Approval from the IBC has been requested for the border crossing.

\subsubsection{Visual Resources}

The land along the proposed action is rolling, except in the Milk River area where the Milk River has cut a canyon into the plain. Agriculture dominates most of the viewshed. The lands managed by the BLM are managed for viewshed by BOR guidelines, and the only key point of observation along the route would be at the Milk River overlooking the canyon.

\subsubsection{Cultural Resources}

Considerable archaeological, historic, and ethnographic research has been conducted on lands within the vicinity of the proposed Wild Horse transmission line. The cultural resources component has involved evaluation of this background material, coupled with additional archival and field research to secure information concerning known sites within the Area of Potential Effect (APE). This research has involved a number of contacts, and field inspections and surveys, as follows:

- The official archaeological records maintained by the State Historic Preservation Office (SHPO) in Helena, Montana; 
- The Department of Natural Resources and Conservation, Division of Trust Land Management, Billings, Montana, concerning known or suspected sites on state lands located within the project;

- The archaeological resource information center maintained by the University of Montana, at Missoula, Montana;

- The National Register of Historic Places (Supplements to 12/94);

- Mr. Michael Andrews, Bureau of Reclamation, Montana Area Office, Billings, Montana, representing Native American interests in the project area;

- Existing published and unpublished documents relevant to environment, prehistory, ethnography, and early historic developments in the vicinity, particularly the recently completed Express Oil Pipeline Report involving lands adjacent to the present project area were researched. These sources provided a general environmental and cultural context by means of which to assess likely site types and distribution patterns for the project area, and are summarized below; and

- Intensive-level pedestrian archaeological surveys were performed along both the Express Pipeline Alternative and the Northwestern Route Alternative, involving lands not previously subjected to archaeological survey.

This section will discuss the results of the research in relation to the cultural history and resources of the project area.

\subsubsection{Prehistory}

The proposed 69-kV electrical transmission line is located in the Northwestern Plains prehistoric cultural subarea. This subarea covers a region which extends from southern Wyoming to central Alberta, and from western Montana to western North Dakota. The prehistory of this subarea, which extends back at least 12,000 years, is characterized by the reliance of the inhabitants on a semi-nomadic hunting and gathering subsistence pattern. Although this pattern lasted throughout the prehistoric time period, the resources which were exploited and the methods used to exploit these resources shifted over time (Express Pipeline Inc. 1993: 2-12).

\subsubsection{Ethnography}

The story of the late prehistoric, protohistoric, and historic Native Americans who lived in and around the project area is the story of continual territorial shifts, expansions, and contractions. These shifts occurred for a variety of reasons, including the development of new life patterns (especially after the introduction of the horse), increased pressures from both Europeans and shifting hostile groups, and the formation of new alliances for defense and trade (Express Pipeline Inc. 1993: 2-18). 
The first tribal group clearly identified near the project area is the Blackfeet, who migrated from the east, reaching the Canadian Plains north of the project area by the 1400 s (Express Pipeline Inc. 1993: 2-18). Several Old Women's Phase sites - the Fresno Site (24HL103), the Cache Site (24HL49) and the Milk River Site (24HL52) - located to the south of the project area, have occupations ascribed to the Blackfeet (Keyser 1979: 148).

After pushing westward to the eastern Montana border by the 1700s, a group made up of the Gros Ventre and Arapahos separated, with the Gros Ventre moving north to the Milk River and then on up to Saskatchewan. By the 1700s, the Comanche had given the horse to the Shoshones, who were then in Wyoming and southwestern Montana. This gave them a decided advantage over the other groups of the high plains. Through use of the horse, they expanded their territory into Alberta and Saskatchewan at the expense of the Blackfeet and Gros Ventre. By the 1750s, the Blackfeet and the Gros Ventre had also obtained horses, and were thus able to reverse this trend. By 1800, small pox and guns had reduced the Shoshones to a mere remanent of their former numbers, with whole bands disappearing (Sturtevant 1986: 517-518). Over the next 100 years, the Blackfeet controlled much territory including that to the north of the Yellowstone River and east of the Rockies.

Ethnographic Description: The introduction of the horse to the northern and northwestern plains by the Shoshones in the early part of the 1700 s radically changed the lifeways of the hunting-gathering people who occupied the plains. The horse provided a rapid means of transportation, allowing the mobility to exploit new territories. Bison could be more easily exploited from horseback, and by about 1800 , the plains groups had evolved into specialized bison hunters. Because of the horse, conflicts over territory became more pronounced. More complex sociopolitical organizations were needed to provide for the common defenses. Small bands and tribes were transformed into large cooperative tribes which fought each other and then Euro-Americans for the control of territory and the resources which came with that territory, of which the bison was the most important resource (Ruebelmann 1983: 69).

The historic Native American peoples of the study area belonged to the northwestern subdivision of the plains cultural area. Although each tribe was different in detail, they shared many common cultural characteristics, most importantly, a nomadic lifestyle which evolved from a subsistence based on horse-mounted bison hunting. Each had a complex social organization, similar religious and ritual practices, a standard sign language, and similar material traits, such as dwelling in tipis, use of bow and arrow and spike clubs, clothing and household articles made of skins decorated first with porcupine quills and later with European beads (Kroeber 1939).

Site Types: A wide variety of site types are recorded in the general and immediate project area (for a more detailed discussion of the various site types see: Express Pipeline Inc. 1993; Keyser 1979; Ruebelmann 1983). As these sites often overlap in content, it is easiest to characterize them in terms of their use (after Ruebelmann 1983: 47-48): 
Habitation Sites: In and around the project area, the most common habitation sites contain tipi rings and cairns. Rock shelters are also a type of habitation site. Materials which may be found at these sites include lithic debris, fire-cracked rock, pottery, fire hearths, groundstone, modified bones, and/or ceramics.

Procurement Sites: The most common procurement site near the project area is the bison kill or jump. Other sites of this type include animal traps, corrals, and food processing areas. These sites are characterized by large quantities of butchered bones, and lithic tools used for killing and butchering such as projectile points, knives, and choppers.

Lithic Quarries and Workshops: Lithic Quarries and workshops are identified by much lithic debitage, cores, quantities of blanks and preforms, and unmodified raw materials such as obsidian, chert chalcedony, porcellanite, quartzites, etc.

Ritual Sites: Ritual sites include burials, petroglyphs, pictographs, and vision quest sites. These sites may occur in conjunction with procurement or habitation sites. Traditional cultural properties generally fall within this site type.

\subsubsection{Historic Context}

Euro-American historic activities in north-central Montana began with the explorations of Lewis and Clark on the Missouri River in 1805. These explorers were followed by other western expeditions and survey parties throughout the 1800 s and even into the early 1900 s (Express Pipeline Inc. 1993: 2-37). Fur trading in Montana began at approximately the same time. The traders followed the early routes of the Native Americans and established the transportation corridors used during this early surveying and trading period (Express Pipeline Inc. 1993: 2-41). Rivers, such as the Milk River, were utilized not only for transportation, but also as a source of water, wood, grass, and game.

The importance of the railroad in bringing immigrant to Montana cannot be overstated; it was the railroads, more than anything else, which paved the way for Montana to become a state in 1889 (Malone and Roeder 1976: 129). In that same year, James Jerome Hill built the Manitoba (Great Northern Railway) rail line across northern Montana, traveling three miles east of Gildford and about 20 miles southwest of the project area (Express Pipeline Inc. 1993).

The river transportation routes and the railroads had to be supplemented by an extensive network of roads, which was developed around this period. Two such roads, built prior to 1913, were noted at the 24HL957 within one-half mile of the survey area. Although no evidence of these was found within the current project area, they are known to have originally connected the Sweet Grass Hills to Wild Horse and Wild Horse to Gildford (Express Pipeline Inc. 1993: 6-121). 
Euro-American settlement came late to the immediate project area. Settlement of the Wild Horse Lake area, located within three miles of the project area, began during the homesteading boom around the turn of the twentieth century. The Boundary Trading Post located at Oldham, near Wild Horse Lake, was opened in 1904, but subsequently closed in 1911. A post office was established in Gildford in 1903, and roads connecting Gildford with Wild Horse and Wild Horse with the Sweet Grass hills were constructed sometime prior to 1913 (Express Pipeline Inc. 1993: 6-120).

Site Types: Various site types would result from the historic period. These include wagon trails and corridors, wagon parts, artifacts, and structural remains related to homesteads or agriculture.

\subsubsection{Prehistoric Resources}

Field work identified the following general conditions within the study area. Approximately 20 miles of the study corridor proceeds through contemporary agricultural fields (Jenson \& Associates, 1996). Ground surface disturbance in these areas is substantial, as lands have been leveled and planted numerous times over the past century. The remaining six miles of the study corridor exhibit varying degrees of ground disturbance. Some areas, such as the southern bluffs over the Milk River, the western part of Section 1 (T37N,R11E), and sections of the corridor adjacent to Highway 232, have been cleared of rocks and probably leveled at sometime in the past, although they are currently not under cultivation. Other areas, such as the lands in Sections 13 and 14 (T36N,R11E) located next to the banks of the Milk River, have built up a natural layer of silt deposit which has obliterated any cultural evidence. Finally, some areas, such as the northern bluffs over the Milk River, remain generally undisturbed.

One prehistoric tipi ring site was recorded (Site JA-2) which consists of three tipi rings and one tipi ring arc. These tipi rings are all single course and are composed of medium-sized (100-150 inches long), deeply buried rocks. Two of the rings and the arc are relatively small (15-18 feet in diameter), while the third ring is unusually large (20-30 feet in diameter). A piece of white quartzite was observed at the site; this did not appear to be a cultural artifact (i.e., a waste flake). Since no temporally diagnostic artifacts or other time indicators were found at the site, the time of occupation is problematic. While this site does contain one unusually large tipi ring, tipi ring sites north of the Missouri River on the Plains of Montana are ubiquitous, especially those lacking artifacts. Therefore, this site appears to have a low potential to yield significant additional information about the prehistory of this region and is considered not eligible to the National Register of Historic Places (NRHP). No other evidence of prehistoric activity was observed in the survey of the study area. This lack of prehistoric cultural evidence is at least partially explained by the extensive agricultural disturbance to which most of the APE has been subjected.

One previously unrecorded prehistoric tipi ring and cairn site (JA-1) was observed. A cursory examination of the site revealed up to 18 tipi rings and three cairns distributed over 
an area of approximately 105,400 square meters. As this site is located outside of the APE and will not be affected by the proposed undertaking, it was not formally recorded during the present project. However, the Division of Trust Land Management of the State of Montana has been notified of the existence and location of the site through receipt of a copy of the present report.

Other cultural sites are known along the Express Pipeline right-of-way and the Milk River. In addition to tipi rings and rock cairns on the north and south bluffs, a medicine wheel site (Site \#795) is located approximately one and one-half to two miles northwest of the 69-kV route.

\subsubsection{Historic Resources}

No evidence of historic-era sites or features was observed within the APE during the pedestrian survey. Again, these results may be at least partially explained by the disturbance to which most of the study corridor has been subjected over the past century.

\subsubsection{Paleontological Resources}

The 69-kV transmission line will cross exposed deposits of the Judith River Formation of Cretaceous age along the north and south sides of the Milk River. The Judith River Formation is known to produce scientifically significant fossils from localities throughout its exposure, including some localities along the Milk River and is cantered to have a high paleontologic potential. The formation consists of grey to yellow massive sandstones, which are interbedded with silty mudstones, bentonitic shales, and lignites. It accumulated in terrestrial to marine environments during the Santonian to Campanian. A nearshore to shoreline marine facies is recognized at the base of the formation in its type area, the Parkman Sandstone Member, which overlies the Claggett Shale (Rogers 1993). A second marine sandstone unit is recognized at the top of the unit in the eastern half of its type area.

\subsubsection{Judith River Formation Resources}

An abundant and diverse assemblage of fossil plant, invertebrate, and vertebrate remains is known from both the terrestrial and nearshore deposits of the Judith River Formation. Fossil plants include a wide variety of ferns: genus Osmunda and Dryopteris; the conifer genera: Sequoia, Thuja, Dammara, and Cunninghamites; and angiosperm genera: Populus, Quercus Sapindus, Diospyros, Castalia, Phyllites, and Carpites (Knowlton, 1900, 1905, 1915). Petrified logs occur commonly in the upper marine sandstone unit.

Fresh water invertebrates from the formation include the mollusks Unio, Sphaerium, Anodonta Campeloma and Goniobasis; and the remains of insects (Meek, 1876; Stanton and Hatcher, 1905). Marine invertebrates known from the nearshore and shoreline deposits of the formation include the mollusks Ostrea, Anomia, Nucula, Melania, and Placenticeras (Stanton and Hatcher, 1905). Trace fossils ichnogenera Ophiomorpha, Skolithos, and Teichichnus are abundant in the upper marine sandstone unit (Rogers, 1993). 
Lower vertebrates known from terrestrial deposits include the fish Ceratodus, Lepisosteus, Myledaphus, Acipenser and Diphyodus; amphibians Scapherpeton and Hemitrypus; turtles Trionyx, Plastomenus, Aspideretes, Basilemys, Baena and Neuranklus; eosuchian Champsosaurus; crocodilians Leidyosuchus and Brachychampsa.; and dinosaurs Gryposaurus, Brachylophosaurus, Chasmosaurus, Aoaceratops, Stegoceras, Euoplocephalus, Edmontonia, a tyrannosaurid, Deinodon, Troodon, Paronychodon, and a protoceratopsian, a lambeosaurid ("Trachodon"), a dromaeosaurid, and an ornithomimid (Marsh 1888, 1889, 1890; Hay 1904; Stanton and Hatcher 1905; Lull and Wright 1942; Sahni 1972; Galton and Sues 1983; Horner 1988, 1993). Eggshell fragments are also known (Clouse 1993, 1995). Those from nearshore and shoreline deposits include the sharks Ischyrhiza, Cretorectolobus, Hybodus, Symechodus, Squalicorax, Eucrossorhinus, Hypotodus, Odontaspis, Plicatolamna, Archaeotriakis, Protoplatyrhina, Ptychotrygon, Chiloscyllium, Ischyodus and Elasmodus; turtle Adocus, crocodile Deinosuchus, and bird Coniomis. Unidentifiable dinosaur bones and mammal teeth have also been reported from nearshore and shoreline deposits (Marsh 1893; Stanton and Hatcher 1905; Holland 1909; Case 1978, 1979).

Mammals known from the terrestrial deposits include the multituberculates Cimexomys, Meniscoessus, Mesodma, Cimolodon and Cimolomys; marsupials Alphadon, Pediomys, and Eodelphis, and insectivore Gypsonictops (Clemens et al. 1979).

Field paleontological surveys have been conducted in the Judith River Formation in the vicinity of the project area for the proposed Altamont and Express Pipelines (Ethnoscience 1991, et seq.; and Winterfeld 1996). These proposed pipeline routes cross the Milk River along a right-of-way corridor adjacent to one of the alternative routes for the transmission line, west of Fresno Reservoir. A field survey along the right-of-way corridor resulted in the discovery of three fossil localities along the banks of the Milk River. The localities produced scientifically significant fossil vertebrate remains, including: (1) the bones and teeth of dinosaurs and other non-dinosaurian reptiles, such as champsosaurs and crocodiles, and fish; (2) turtle shell fragments; (3) ossified dinosaur tendons; (4) egg shell fragments; (5) shells of freshwater bivalves; and (6) petrified wood.

\subsubsection{Technical Analysis and Field Suroey}

A technical analysis of existing data was triggered by the occurrence of noteworthy fossils and includes a study of published and unpublished paleontologic literature and institutional records. Compilation and technical analysis included:

- A search of library or literature databases for relevant published and unpublished work on the paleontology of the area and geologic units to be impacted;

- A search of institution records to determine whether paleontologic resources have been found in the area to be impacted; 
Critical evaluation of the information and recommendations for further action.

A paleontological field survey was conducted based upon the findings of the technical analysis. Technical analysis conducted for the proposed Altamont and Express Pipelines in the vicinity of the project area have documented the need for field survey for paleontologic resources along the banks of the Milk River. The focus of the field survey was to locate paleontologic resources within the boundary of the project area and formulate actions to be taken to prevent or mitigate adverse impacts to those resources.

A detailed pedestrian survey of the proposed transmission line alternative routes to locate fossils during the week of August 19, 1996. Dinosaur and non-dinosaurian reptilian fossil remains were evident along each of the routes in the Judith River Formation. None of the remains along any of the three alternatives require further preconstruction mitigation. No specimens were collected during the visit as stipulated by field authorization from the BOR.

Following the completion of the field survey, a report, including a technical analysis of existing data and the findings of the field survey, will be submitted to federal agencies involved in the project.

\subsubsection{Socioeconomic and Community Resources}

The socioeconomic characteristics in the area of the transmission line route are those characteristic of western agriculture areas. Most of the community is comprised of farmers and ranchers. Hill County has a density of 6.1 people/square mile, and it's population has decreased 1.8 percent from 1980 to 1990 . The 1990 population of Hill County was 17,654 people. Of these people, 73.2 percent were born in the state, and 1.9 percent were born in foreign countries.

The Havre area has 365 hotel rooms and 601 tent and trailer spaces. In general, occupancy rates during high-season are 82 percent, and during the off-season are 50 percent.

The median household income in 1990 for Hill County was $\$ 25,467$. The median income for families was $\$ 31,057$ and for nonfamilies was $\$ 12,932$. Per capita income was $\$ 11,121$. In 1990, approximately 18 percent of all persons in Hill County were below the poverty level.

The economy is typical of rural eastern Montana, with a mixture of ranching and farming. The major crops are dry land wheat and barley, with cattle production predominant on the grasslands. The population is sparse in the rural areas, with the number of farms continuing to decline. Irrigation loads have stabilized from a steady decline from 1985 to 1989, and are expected to remain stable over the next four years. The Cooperative also 
serves a number of small oil wells in three different oil fields. Because of depressed oil prices, the drilling and production of oil has decreased substantially in the past 10 years.

\subsubsection{Transportation and Noise}

Transportation: Transportation facilities along the proposed action consist mostly of dirt and gravel roads adjacent to farmland. Except for the Milk River area, the proposed action would follow at the sides of these roads. The Proposed Express Alternative would parallel along Route 232 for the five miles south of the Canadian border.

Noise: Human response to noise is very subjective. Noise that one person would find enjoyable could be very annoying to another. Decibel $(\mathrm{dB})$ is the unit used to measure sound levels. The human ear has a limited range of sensitivities to noise levels, and thus a scale better reflecting human hearing was developed. This "weighted" scale is called the "A-weighted" scale and is denoted as dBA. A measure frequently used to relate environmental noise is the day-night sound level (Ldn).

Ambient noise levels are 35 to $40 \mathrm{dBA}$ Ldn in the project area. The existing noise environment is primarily a function of residential and agricultural sources. The project area is a rural agricultural location, with few homes or nearby residences to be potential noise receptors or impacted by construction equipment and truck traffic noise. Within the Milk River Canyon, the noise levels experienced are greatly influenced by topography since the steep canyon walls tend to intensify noise levels. Noise levels would also vary by season, since heavy snowfall serves to muffle ambient noise and since much less activity occurs during this time of year.

\subsubsection{Environmental Justice}

Due to the isolation of the transmission line, no effect to any group's lifestyle would occur. Only one house is within 100 yards of the transmission line. No currently active schools are located within five miles of the transmission line. The only public facility located within a mile of the transmission line is the United States and Canadian government custom stations at the Wild Horse Port-of-Entry.

No American Indian Tribes or reservation lands are located along the proposed transmission line route.

\section{$3.2 \quad$ Northwestem Route Alternative}

\subsubsection{Air Quality}

Same as proposed Express Route Alternative.

\subsubsection{Geology and Soils}

Same as proposed Express Route Alternative. 


\subsubsection{Surface Water and Floodplains}

Same as proposed Express Route Alternative.

\subsubsection{Wetlands}

Ephemeral wetland complexes occur along the Northwestern Route Alternative in Section 10 (T36N,R10E), and Sections 26 and 34 (T37N,R10E) (see Appendix A). The "prairie potholes" located in Section 10 (T36N,R10E) (approximately 2.2 acres), and Section 26 (T37N,R10E) (approximately 2.5 acres), were dry clay bottoms at the time of the July 16, 1996, surveys. Vegetation remnants were species typical of temporary or seasonal wetlands. Plant species included foxtail barley (Hordeum brachyantherum), navarettia (Navarettia intertexta), cudweed (Gnaphalium palustre), curly-leaved buckwheat (Rumex crispus), and speedwell (Veronica peregrina). The wetlands have a species composition similar to those present in prairie wetlands encountered outside of the Northwestern Route Alternative corridor.

The wetland in the southeast quarter of Section 34 (T37N,R10E), had a species composition similar to the prairie potholes. However, Great Plains cottonwood were also growing along the edges. This wetland is probably part of an intermittent drainage. The right-of-way would cross approximately 0.1 acre of the drainage. Killdeer and northern harrier were observed at the wetland.

The Spring Coulee, an intermittent drainage, would be crossed by the Northwestern Route Alternative at Section 11 (T37N,R11E). The coulee was dry on July 25, 1996. The coulee has a species composition dominated by bluegrass, Nebraska sedge, amphibious sorrel, and Baltic rush. The right-of-way would cross approximately 0.23 acre of the Spring Coulee.

The riparian and floodplain area along both sides of the Milk River are dominated by silver sage and western wheatgrass (Agropyron smithii).

\subsubsection{Aquatic Ecology}

Same as the proposed Express Route Alternative:

\subsubsection{Vegetation}

The plant communities that occur along the proposed powerline route occur within a landscape that has been transformed largely by agriculture. Much of the land is used for growing wheat. The route does pass through excellent examples, although intensively grazed, of native perennial grasslands dominated by needle-and-thread grass (Stipa comata) and blue grama (Bouteloua gracilis). In places along the bluffs of the Milk River, rough fescue (Festuca scabrella) is a dominant grass in the perennial grassland: The native grassland communities occur on the high bluffs adjacent to the Milk River on both the north and south sides. The eroding clay slopes of the bluffs facing the river and the coulees among the bluffs also have native plant communities dominated by silver sage (Artemisia cana) and yellow buckwheat (Eriogonum flavum). In the past, native perennial grasslands and 
clay butte and coulee plant communities were widespread in the region. While these plant communities are not rare, ranching and farming have converted much of the landscape to other uses so that examples of typical, healthy prairie lands are becoming less common. Many areas have been invaded by exotic species such as sweet honey clover (Melilotus officinalis):

The FWS and MNHP were contacted regarding known and potential occurrences of specialstatus species in the study area. The FWS did not identify any special-status plant species with potential to occur within the study area (FWS 1996). The MNHP identified threelobed beggarticks (Bidens comosa) and desert groundsel (Senecio eremophilus var. eremophilus) as potentially occurring in the study area (MNHP 1996). Both of these species are stateranked 1. Big sagebrush/rough fescue habitat type was also identified by MNHP as potentially occurring in the study area.

The proposed alignment was surveyed on July 16 and 25, 1996, for special-status species and their habitats (Appendix C). Surveys were conducted within a 40-foot corridor on foot and by vehicle. All species observed were recorded.

Threelobed beggarticks and desert groundsel were not encountered. The closest known locations of these species are located in Beaver Creek County Park, approximately 60 miles southeast of the study area. The big sagebrush/rough fescue habitat type does not occur in the project area. The nearest known location is south of Beaver Creek County Park, approximately 60 miles southeast of the study area.

Five plant communities were encountered along the Northwestern Route Alternative. No special-status species or plant communities were encountered. Appendix B contains a list of species encountered.

Roadsides and wasteplaces: This plant community occurs along roadsides and between fields of wheat. Crested wheatgrass (Agropyron cristatum) and smooth brome (Bromus inermis) are usually dominant species because they are used on road shoulders by highway crews.

Hedgerows: The dominant species of hedgerows include two shrub species that reach a height of about five to eight meters: Siberian pea (Caragana arborescens) and Russian olive (Elaegnus angustifolia). The hedgerows are located primarily in Section 14 (T36N,R10E) and Section 11 (T37N,R11E).

Native perennial grasslands: The grasslands along this route are dominated by needle-andthread grass and blue grama. Rough fescue is also a dominant grass in places. Fringed sage (Artemisia frigida) and silver sage occur as a scattered subshrub and shrub component in the perennial grasslands. 
Fallow cultivated pasture: These are lands among the wheat fields that have been planted to crested wheatgrass and smooth brome. These lands are likely part of the CRP program.

Exposed clays and coulees: These areas occur along the Northwestern Route Alternative in the coulees on the north side of the Milk River and on clay bluff faces adjacent to both sides of the river. Silver sage and yellow buckwheat are dominants.

\subsubsection{Wildlife}

The study area is primarily cropland (wheat), with native perennial grasslands used for grazing along the bluffs of the Milk River. Species commonly encountered included western meadowlark (Sturnella neglecta) and horned lark (Eremophila alpestris). Please refer to Appendix $C$ for a list of species encountered.

The FWS and MNHP were contacted regarding known and potential occurrences of specialstatus species in the study area. The FWS identified three listed species with potential to occur within the study area (FWS 1996). These species were the threatened bald eagle (Haliaeetus leucocephalis), and the endangered black-footed ferret (Mustela nigripes) and peregrine falcon (Falco peregrinus). The MNHP identified desert shrew (Sorex nanus), stateranked 3, as potentially occurring in the study area (MNHP 1996).

The Northwestern Route Alternative was surveyed for special-status species and their habitats on July 16 and 25, 1996 (Appendix C). Surveys were conducted within a 40-foot corridor on foot and by vehicle. All species observed were recorded.

No special-status species were encountered. Appendix C contains a list of species encountered.

Potential habitat for bald eagle occurs at the Milk River crossing. Bald eagle breeds on coasts, rivers, and large lakes in open areas, often building nests in the forks of tall trees or on cliffs (Ehrlich et al. 1988). The study area does not provide nesting habitat in tall trees, but sandstone cliffs along the Milk River could potentially be used. It is unlikely that bald eagle would nest in the vicinity of the Milk River crossing as it is poor habitat for prey items such as fish, small mammals, and waterfowl. There are no known bald eagle nest sites within one mile of the study area (FWS 1996) and it is unlikely that this species occurs in the area other than as a seasonal migrant.

Peregrine falcons usually nest on cliffs in open habitats from tundra, savanna, and coastal areas to high mountains and open forests (Ehrlich et al. 1988). While the Milk River crossing provides sandstone cliffs that may be potential nesting habitat, it is unlikely that this species occurs in the area other than as a seasonal migrant.

There is no habitat for black-footed ferret in the study area. This species is found in prairie dog towns. No prairie dogs towns are located within the study area. 
The closest known location of desert shrew is approximately 70 miles south of the study area on the summit and north slopes of Baldy Mountain, in the Bearpaw Mountains south of Havre, Montana (MNHP 1996).

The Milk River is considered mule deer (Odocoileus hemionus) winter range. Mule deer and their signs were observed in the Milk River canyon and bluffs during surveys. Mule deer were also observed along the alignment in cropland in Section 26 (T36N,R10E) and CPR lands in Section 26 (T37N,R10E).

Northern harriers (Circus cyaneus) were observed foraging over cropland and native perennial grasslands along the alignment in Section 26 (T36N,R10E) and Section 11 (T37N,R10E). A northern harrier was also observed emerging from a hedgerow in Section 11 (T37N,R11E). No other raptor species were observed within the alignment.

Hedgerows consisting of crested wheatgrass (Agropyron cristatum), Siberian pea (Caragana arborescens), wavy-leaved thistle (Cirsium undulatum), Russian olive (Elaeagnus angustifolia), divergent fleabane (Erigeron divergens), and Great Plains cottonwood (Populus deltoides) provide habitat for numerous small birds and raptors. Hedgerows near the alignment are located in Section 14 (T36N,R10E) and Section 11 (T37N,R11E).

Ephemeral wetlands are located in Section 10 (T36N,R10E) and Sections 26 and 34 (T37N,R10E). A killdeer (Charadrius vociferus) and a northern harrier were observed at a drainage in Section 34 (T36N,R10E). No other waterfowl were observed in the wetlands.

The Spring Coulee will be crossed by the Northwestern Route Alternative at Section 11 (T37N,R11E). The coulee was dry on July 25,1996 , and no waterfowl or other wildlife species were observed.

The Milk River is the only other waterbody crossed at Sections 14 and 23 (T37N,R10E). This area provides poor quality habitat for waterfowl. There is no standing water in the floodplain and the river edges and sandbars provide little cover for waterfowl. The Milk River is highly turbid and silty in this area. Surrounding uplands consist of alkaline soils with vegetation such as saltgrass (Distichlis stricta) and buffaloberry (Shepherdia argentea). A flock of waterfowl (approximately $15-20$ individuals) were observed on a sandbar approximately 0.25 mile east of the alternative crossing. The birds were out of range and could not be identified.

\subsubsection{Existing and Planned Land Use}

Same as the Express Route Alternative except private lands, all of which are farmed, comprise $\mathbf{2 1 . 5}$ miles of the transmission line, and Montana State lands comprise 0.5 miles of the transmission line. 


\subsubsection{Visual Resources}

Same as the Express Route Alternative.

\subsubsection{Cultural Resources}

About 85 percent of the Northwest Alternative corridor proceeds through contemporary agricultural fields. As with the proposed route corridor, the ground surface in these areas has been substantially impacted through numerous levelings and plantings over the past century. The remaining fifteen percent of the corridor exhibits varying degrees of ground disturbance. Portions of Section 14, T37N, R10E immediately next to the Milk River, have experienced the natural deposition of heavy layers of silt, which may have either destroyed or possibly covered cultural material in this area. Some areas, such as the southeastern corner of Section 11, and a small portion of the southern half of Section 23, T37N, R10E, appear largely undisturbed with the exception of a small quarried area and bulldozed access roads through a portion of the southeast corner of Section 11.

Three prehistoric sites and one isolated flake have been identified along the Northwest Alternative route.

One prehistoric site and one isolated flake represent newly recorded sites, both of which occur along the Northwest Alternative corridor. Site JA-3 is located in Section 23 on a peninsula, surrounded on three sides by ephemeral tributaries of the of the Milk River. The lands are privately owned. The site consists of (1) a rock alignment constructed against a natural rock outcrop, (2) four rock cairns and a scattering of loose rock, (3) an additional rock cairn, and (4) one possible tipi ring arc. All the cairns are small, consisting of less than ten rocks each. Other scattered rocks, situated nearby, may have once formed tipi rings, although only one possible tipi ring arc was observed in the site area. Although a thorough investigation of the surrounding area was undertaken, no additional cultural materials or features were noted and the purpose of the rock alignment at site JA-3 remains undetermined. A minor historic component, consisting of a wood and metal-framed wagon base or truck chassis, was recorded ten meters to the east of the easternmost rock cairn at JA-3. As no artifacts were found at this site, and as there is no way to date the prehistoric component, this site is not considered eligible for inclusion on the National Register of Historic Places.

A solitary tipi ring (JA-4) was observed east (outside) of the Northwest Alternative on top of the southern bluff overlooking the Milk River in Section 23. This ring, which measured between five and six meters in diameter, was made up of a single course of larger (39-79 inches in length) rocks which are deeply silted. Although there were no breaks observed in the ring, a small cluster of five rocks was observed in the north side of the ring.

One small purple chalcedony flake ("JA-5") was observed in the eastern track of a two-track dirt road within the Northwest Alternative study area in Section 35. Although the area was examined carefully, no additional flakes or associated features were found. 
One previously recorded prehistoric site (24HL1046) was observed along the Northwest Alternative corridor within Section 11 on privately owned lands. The site was first identified and recorded in 1994, and was described as containing fourteen stone circles on a narrow ridge overlooking the valley floor. The rings average fifteen feet in diameter and rise above the surface about six inches. No additional features and no artifacts were observed in association. The site is essentially undatable, contains no artifacts (including especially no temporally diagnostic tools), and does not retain data considered important to local or regional prehistory. Based on two separate field observations and following site recording, it is recommended that the site is not a National Register eligible property, and the present level of documentation is recommended as adequate mitigation of any potential effects which might accompany construction or maintenance of the proposed transmission line through this area.

\subsubsection{Paleontological}

Same as the proposed Express Route Alternative.

\subsubsection{Socioeconomic and Community Resources}

Same as the proposed Express Route Alternative.

\subsubsection{Transportation and Noise}

Same as the proposed Express Route Alternative.

\subsubsection{Environmental Justice}

Same as the Express Route Alternative.

\subsection{Cottonwood Route Alternative}

This would be the same as the proposed Express Route Alternative except for the following.

\subsubsection{Wetlands}

The only wetlands affected by the Cottonwood Route Alternative are in the Milk River floodplain, where an extensive assemblage of wetlands and ponds are found (Sections 10 and 11, T35N,R12E). These are shown in Appendix A.

\subsubsection{Wildlife}

The area of the Milk River provides excellent habitat for waterfowl and raptors, with standing water and sandstone cliffs. An immature golden eagle and numerous swallows were observed during site visits in July 1996, and numerous raptor casts were observed under the two-pole transmission tower on the eastern river bluff.

\subsubsection{Cultural Resources}

The same cultural resource setting as the previous two alternatives was found on this alternative. At the Milk River crossing, several known sites were recorded. 


\subsection{No Action Alternative}

In the No Action Alternative, the electric transmission line would not be built and the Wild Horse pumping station but diesel engines would be installed there. There would be minor, localized air quality impacts from operation of the diesel engines at the Wild Horse pumping station. This would result in the following increase in annual emissions for these constituents:

$$
\begin{aligned}
& \mathrm{NO}_{\mathrm{x}}-329 \text { tons/yr. } \\
& \mathrm{CO}-11 \text { tons/yr. } \\
& \mathrm{VOCs}-14 \text { tons/yr. } \\
& \mathrm{SO}_{2}-16 \text { tons/yr. }
\end{aligned}
$$

In view of the existing site air quality, these increased air quality impacts are not considered significant on a regional airshed basis.

\subsection{Proposed Express Route Alternative}

\subsubsection{Air Quality}

Air quality impacts that may result from the project include emissions during construction and operation (post-construction). Project construction activities would have an impact on local air quality through the release of 1) gaseous emissions and particulates from construction vehicles powered by both gasoline and diesel IC engines, and $2 \mathrm{~b}$ ) dust (particulates).

Vehicle emissions would primarily consist of nitrogen oxides $\left(\mathrm{NO}_{x}\right)$, carbon monoxide $(\mathrm{CO})$, volatile organic compounds (VOCs), and particulate matter $\left(\mathrm{PM}_{10}\right)$, as well as smaller amounts of sulfur dioxide $\left(\mathrm{SO}_{2}\right)$, and other trace emissions. Dust raised by project construction would include both $\mathrm{PM}_{10}$ and larger size particulate matter.

The effects of these construction related emissions on ambient air quality would be temporary and are not expected to cause exceedences of either the federal or Montana AAQS. However, construction activities will not result in significant air quality impacts when following mitigation measures described in Section 2.2 .2 are implemented.

During project operations, the only (negative) air quality impacts anticipated locally would result from vehicular emissions associated with periodic inspections/ maintenance and the generation of small amounts of ozone from the transmission line itself. These impacts are not considered significant. 
While project operation (i.e., the use of a transmission line and electric motors to run the Wild Horse pumping station), would result in virtually no local air emissions, the use of utility grid-supplied electricity to run the pumping station would result in the consumption of fuel by the utility supplying the power. Since the power for the Wild Horse pumping station would be delivered through the Basin Electric Power Cooperative (Basin Electric) utility grid, it is assumed that the necessary power would be generated at one of the Basin Electric power plants.

Basin Electric is headquartered in Bismark, North Dakota, and has a capacity of approximately $3,300 \mathrm{MW}$, two-thirds of which is coal-fired. Based on discussions with Basin Electric and given the location of the Wild Horse pumping station, it is most likely that power would be supplied from Basin facilities on the west side of the east-west intertie (Westside power) or the Antelope Valley Generating Station. These facilities incorporate scrubbing technology for $\mathrm{SO}_{2}$ control, baghouses or electrostatic precipitation for $\mathrm{PM}_{10}$ control, and operate in compliance with the proposed $\mathrm{Phase} I I \mathrm{NO}_{\mathrm{x}}$ reductions requirements of Title I of the 1990 Federal Clean Air Act Amendments.

The 3.7 MW needed on average to operate the pumping station motors represents less than 0.12 percent of Basin Electric's generating capacity. If Basin Electric operates at 50 percent of its capacity on average, the power needed for the Wild Horse station would be less than one quarter of one per cent ( 0.25 percent) of Basin's output. If the $3.7 \mathrm{MW}$ of power needed for the pumping station were to result in a $3.7 \mathrm{MW}$ increase in the Basin Electric system's overall output, the utility's incremental amounts of additional fuel consumption, stack emissions and related emissions impacts resulting from the generation of this would be approximately of the same relative size, and therefore, would not be significant, when viewed in a regional context. However, rather than increase total system outputs to supply power to the pumping station, it is our understanding that Basin Electric would supply the necessary power through a reduction of its spot market sales. This mode of operation would result in no increases in Basin Electric's emissions due to the pumping station.

In order to estimate the magnitude of potential air emissions impacts on a local level (assuming that spot market sales are not reduced), the incremental air emissions resulting from the generation of power for the pumping station were assumed to be released from one of the Basin Electric generating stations. The Antelope Valley facility in Beulah, North Dakota was selected for this purpose. As it consists of two $450 \mathrm{MW}$ units, and is coal-fired,

3. On a day-to-day basis, the actual location of where the incremental power needed for the pumping station would be generated would vary, so it not possible to identify a definite location or combustion source within the Basin Electric generating system that is associated with the pumping station's power requirements. (On occasions, the power required for the pumping station could be imported into the Basin system via interconnections to other generating sources.) However, the assumption that the necessary pumping station power would be generated by Basin Electric most of the time is a reasonable one for this assessment. 
Antelope Valley provides a reasonable size and worst-case fuel type for evaluating the Wild Horse pumping station's incremental emissions.

Typical air emissions factor, heat rate, and stack height data for the Basin system were used to estimate emissions associated with the power requirements. These emissions were compared to the 1994 annual emissions for the Antelope Valley facility. This comparison; which is shown in Table 4-1, indicates that the emissions associated with the power needed for the Wild Horse pumping station amount to less than 1 percent of Antelope Valley's emissions.

Table 4-2 compares the modelled impacts that result from the emissions due to the pumping station's power requirements to the 1994 modelled impacts of Antelope Valley's emissions. These two sets of emissions impacts are in turn compared to the applicable NAAQS. As shown in Table 4-2 the impacts associated with emissions that result from power generated for the Wild Horse pumping station are less than 1.5 percent of the impacts that resulted from Antelope Valley's 1994 emissions. Table 4-2 also notes that the modelled impacts for the pumping station's emissions are below the EPA's established de minimis levels in all cases. Since the Antelope Valley's 1994 impacts were all well below the applicable NAAQS and the pumping station's impacts are a small fraction of the generating station's impacts (as well as below the EPA de minimis levels), the potential air emissions impacts resulting from emissions associated with pumping station power requirements are not considered significant.

\subsubsection{Geology and Soils}

Temporary disturbance of the ground surface, as well as increased compaction and erosion, could occur during construction. Compacted soils would be disked or ripped as appropriate, and disturbed areas would be reseeded. All restoration will be in accordance with the Express Pipeline EIS Preliminary Restoration Plan (BLM, 1995). Appropriate erosion control measures will be taken if construction needs to be done on slopes as set forth in the Express Pipeline Preliminary Restoration Plan (BLM, 1995).

\subsubsection{Surface Water}

The width of the Milk River at the crossing is approximately 150 feet. The agricultural impoundment is approximately 60 feet wide. The other intermittent and dry coulees are no wider than 30 feet. The transmission line will span over all these water bodies and their banks. No construction or operation activities will take place in streams, thus no impacts would occur. 


\begin{tabular}{|c|c|c|c|c|c|}
\hline \multicolumn{6}{|c|}{$\begin{array}{l}\text { Table 4-1 } \\
\text { Estimated Emissions from Power Generated for the Wild Horse Pumping } \\
\text { Station Compared to } 1994 \text { Emissions at the Antelope Valley Generating Station }\end{array}$} \\
\hline \multirow{2}{*}{ Pollutant } & \multirow{2}{*}{$\begin{array}{c}\text { Basin } \\
\text { Electric } \\
\text { Emission } \\
\text { Factors } \\
\text { (lb/MMBtu) }\end{array}$} & \multicolumn{2}{|c|}{$\begin{array}{l}\text { Estimated } \\
\text { Emission Rate } \\
\text { Per } \mathbf{M W}^{\mathbf{1}}\end{array}$} & \multirow{2}{*}{$\begin{array}{c}\text { Emissions } \\
\text { from Wild } \\
\text { Horse } \\
\text { Load } \\
\text { (ton/year) }\end{array}$} & \multirow{2}{*}{$\begin{array}{l}1994 \text { Antelope } \\
\text { Valley Station } \\
\text { Emissions } \\
\text { (tons/year) }\end{array}$} \\
\hline & & (lb/hour) & (ton/year) & & \\
\hline $\mathrm{SO}_{2}$ & 0.6 & 6.7 & 29.4 & 108.7 & 14,410 \\
\hline $\mathrm{NO}_{\mathbf{x}}$ & 0.5 & 5.59 & 24.5 & 90.5 & 11,458 \\
\hline VOCs & 0.004 & 0.045 & 0.20 & 0.72 & 283 \\
\hline $\mathrm{CO}$ & 0.03 & 0.335 & 1.47 & 5.43 & 750 \\
\hline $\mathrm{PM}_{10}$ & 0.03 & 0.335 & 1.47 & 5.43 & 754 \\
\hline
\end{tabular}

1

Based on a plant heat rate of $11,174 \mathrm{Btu} / \mathrm{kWh}$.

2 Assumes an annual average load of $3,700 \mathrm{~kW}$ (equivalent to $32,412,000 \mathrm{kWh}$ per year).

Based on data from EPA AIRS Executive Data Base. The CO value is an estimate. In AIRS it is indicated that the $\mathrm{CO}$ emissions are less than 1000 tons/year. 


\begin{tabular}{|c|c|c|c|c|c|}
\hline \multicolumn{6}{|c|}{$\begin{array}{l}\text { Table 4-2 } \\
\text { Modeled Ambient Impacts of the Antelope Valley Generating Station with } \\
\text { Additional Generation to Support the Wild Horse Pumping Load }\end{array}$} \\
\hline \multirow{2}{*}{ Pollutant } & \multirow{2}{*}{$\begin{array}{l}\text { Ave. } \\
\text { Time }\end{array}$} & \multicolumn{3}{|c|}{ Modeled Peak Ambient Impact (ug/m³) } & \multirow{2}{*}{$\begin{array}{c}\text { National } \\
\text { Ambient Air } \\
\text { Quality } \\
\text { Standard } \\
\left(\text { ug } / \mathbf{m}^{3}\right)\end{array}$} \\
\hline & & 1994 & $\begin{array}{l}\text { With Wild } \\
\text { Horse }^{3}\end{array}$ & Total & \\
\hline $\mathrm{SO}_{2}$ & $\begin{array}{l}\text { 3-hr } \\
\text { 24-hr } \\
\text { Annual }\end{array}$ & $\begin{array}{l}257.5 \\
85.8 \\
28.6\end{array}$ & $\begin{array}{l}3.67 \\
1.22 \\
0.22\end{array}$ & $\begin{array}{l}261.1 \\
87.0 \\
28.8\end{array}$ & $\begin{array}{c}1300 \\
365 \\
80\end{array}$ \\
\hline $\mathrm{NO}_{2}$ & Annual & 22.7 & 0.18 & 22.9 & 100 \\
\hline $\mathrm{CO}$ & $\begin{array}{l}\text { 1-hr } \\
\text { 8-hr }\end{array}$ & $\begin{array}{l}14.9 \\
10.4\end{array}$ & $\begin{array}{l}0.20 \\
0.14\end{array}$ & $\begin{array}{l}15.1 \\
10.6\end{array}$ & $\begin{array}{l}40,000 \\
10,000\end{array}$ \\
\hline $\mathrm{PM}_{10}$ & $\begin{array}{c}24-\mathrm{hr} \\
\text { Annual }\end{array}$ & $\begin{array}{l}4.5 \\
1.5\end{array}$ & $\begin{array}{l}0.06 \\
0.01\end{array}$ & $\begin{array}{l}4.6 \\
1.5\end{array}$ & $\begin{array}{l}150 \\
50\end{array}$ \\
\hline
\end{tabular}

Impacts are based on the SCREEN3 model and the use of averaging time adjustment factors. These factors adjust the 1-hour SCREEN3 estimated impacts to other averaging times. The factors are:

3-hours: 0.9

8-hours: 0.7 24-hours: 0.3

Annual: 0.1

The emission rates used to determine these impacts vary depending on the averaging time. The annual average impacts are based on emissions associated with the annual average load of $3,700 \mathrm{~kW}$. Impacts for averaging times of 24 -hours or less are based on emissions associated with the maximum load of $7,000 \mathrm{~kW}$.

3 The incremental increase in impacts associated with meeting the Wild Horse pumping loads falls well below EPA's established de minimis impact levels. The de minimis levels are as follows:
$\mathrm{SO}_{2}: \quad \begin{aligned} & \text { 3-hour }=25 \mathrm{ug} / \mathrm{m}^{3} \\ & 24 \text {-hour }=5 \mathrm{ug} / \mathrm{m}^{3}\end{aligned}$
$\mathrm{PM}_{10}: \quad 24$ hour $=5 \mathrm{ug} / \mathrm{m}^{3}$
Annual $=1 \mathrm{ug} / \mathrm{m}^{3}$
Annual $=1 \mathrm{ug} / \mathrm{m}^{3}$
CO: $\quad$-hour $=2,000 \mathrm{ug} / \mathrm{m}^{3}$
$\mathrm{NO}_{2}: \quad$ Annual $=1 \mathrm{ug} / \mathrm{m}^{3}$
8-hour - $500 \mathrm{ug} / \mathrm{m}^{3}$ 


\subsubsection{Wetlands}

No construction or operation would occur in wetlands. No equipment would enter wetlands, and poles will be placed outside wetlands so conductors would overspan them, conductor stringing operations would work from outside wetland areas. Construction adjacent to wetlands would follow procedures set forth in the Express Pipeline EIS Rehabilitation Plan. This plan includes specific procedures for clearing of areas, for erosion control, and for sedimentation control for construction in areas which could affect wetlands. Pole placements in relationship to wetland areas will be 150 feet from the agricultural impoundment, and 250 feet away from the water on the Milk River. For other drainages, poles will be kept at least 100 feet from the edge of wetlands.

\subsubsection{Aquatic Ecology}

No construction or operation activities would occur in rivers or streams, thus no impacts to aquatic ecology would occur.

\subsubsection{Vegetation}

Construction of the transmission line could create increased erosion and sedimentation due to clearing of ground cover. Any vegetation disturbed during construction will be reseeded. No new access roads will need to be built. Vegetation will be restored according to the Preliminary Restoration Plan in the Express Pipeline EIS (BLM, 1995).

The Montana County Noxious Weed Management Act will be adhered to during construction to reduce the possibility of spreading noxious weeds. In order to prevent the spread of noxious weeds, all equipment brought in from other areas will be thoroughly cleaned with high pressure water before operation. Currently, equipment would be coming from either Chinook, Montana, or Wyoming.

\subsubsection{Wildlife}

Waterfowl: The wetland/pond at the agricultural impoundment, located at the junction of Sections $22,23,26$, and 27 (T36N,R11E), will be crossed by the transmission line. However, there is potential for waterfowl collisions with the proposed transmission line. In order to minimize this potential impact, helical wrap markers will be placed on the conductor at the crossing to increase visibility of the line to waterfowl.

The proposed crossing at the Milk River provides poor quality habitat for waterfowl. No waterfowl species were observed at the crossing during the survey and no significant impacts are expected. However, to decrease the potential for waterfowl collisions with the proposed transmission line, helical wrap markers will be placed on the lines to increase their 
visibility. Additionally, the shield wire will be removed from the lines at the crossing. Studies have indicated that 50 percent of waterfowl collisions with transmission lines occur when birds strike the shield wire above the conductors. An $\mathrm{H}$-frame design will be used at the crossing to further reduce the potential for waterfowl collisions by placing all three conductors within the same horizontal plane.

Raptors: Suggested raptor protection design (Avian Power Line Interaction Committee (APLIC) 1996) will be used in pole design to reduce the likelihood of raptor electrocutions.

The prairie falcon nest located during the May 1, 1996, raptor surveys for the Express Pipeline is not within the proposed crossing corridor and is located more than 1/4 mile from the line. The ferruginous hawk nest is located adjacent to the proposed corridor. During the July 24, 1996, field survey, there were no signs of recent activity at the ferruginous hawk nest. In order to minimize disturbance to the raptors and their nests, the proposed transmission line will be constructed outside of the nesting season.

\subsubsection{Existing and Planned Land Use}

Most poles will be placed outside cultivated land and construction will largely take place from roads and trails. However, in some instances it may be necessary to work on cultivated land during construction. A temporary loss of farmland could occur. The Express Route Alternative is not expected to increase growth in the project area.

\subsubsection{Visual Resources}

No significant visual impacts are expected from the presence of the transmission line from any of the view points along the route, except for poles that will be visible on the horizon $3+$ miles away from the viewshed on the north bluff of the Milk River from Section 11 (T36N,R11E).

\subsubsection{Cultural Resources}

Site JA-2 contains only surface features, without associated cultural deposits, artifacts, or specialized dating samples (as determined through trowel probes of the surface to 2 to 4 inches depth within individual features). Consequently, further research (i.e., data collection or data recovery) is not likely to yield additional information from either of these sites. concerning prehistoric patterns of settlement or land use, economic activities, or dating.

Based on the present site recording and surface inspection, the JA-2 site is not eligible for inclusion on the NRHP. Because site JA-1 is not in the project area, it will not be impacted. 
In addition, sites identified on the north bluff overlooking the Milk River in Site \#779, and on an island in the river (Site \#806) will be avoided. The proposed Express Route Alternative has been aligned to the maximum extent possible to avoid any direct or indirect impacts to areas of known cultural resources, either through tower placement, guy wires, or access roads. Express access roads and existing two-track trails will be used to prevent damage to cultural sites by vehicles.

After leaving the Milk River valley, there are no known cultural sites within the APE to the Canadian border.

The present evaluation and recommendations are based on the findings of an inventorylevel surface survey only. There is always the possibility that potentially significant unidentified cultural materials could be encountered on or below the surface during the course of future development or construction activities. An archaeological consultant will be on-site during construction in designated sections where cultural sites are known to occur in the right-of-way or adjacent lands.

In the event of the discovery of human remains which predate the historic period, or remains which may be identified as the remains of Native Americans from the historic period, all involved parties must follow the provisions laid out in the Native American Graves Protection and Repatriation Act of 1990 (P.L. 101-601; 104 Stat. 3048). As it is possible that human remains and associated cultural artifacts may be inadvertently discovered during project construction, early consultation with local Native American groups regarding the treatment and disposition of such remains and artifacts is planned.

\subsubsection{Paleontological Mitigation}

It is likely that ground disturbance associated with construction of the project will encounter fossils of scientific significance. Adverse significant impacts would occur if fossil resources were disturbed during construction and beneficial significant impacts would occur if fossil resources were discovered. Specific measures will be taken to mitigate potential adverse impacts to any possible fossil resources in areas underlain at the surface, or within a few feet of the surface, by the Judith River Formation. These measures will include the following:

- A paleontologist will be on-site during construction to monitor activities on the Milk River which may affect paleontological resources. Monitoring would include examination of excavation and associated spoil piles; 
- Sample (about $250 \mathrm{lbs}$ ) is to be screened from one of the localities (Fresno \#2) to secure a collection of small fossil vertebrates preserved at the locality;

- Instruction will be provided to construction personnel on the types of fossils that may be encountered and the steps to be taken should any fossils be uncovered during general construction;

- Instruction will stress that collection or excavation of fossil materials from federal lands is illegal. This information can be conveyed verbally or in a short brochure/handout made available to construction personnel;

- Contingency plans will be prepared which may redirect construction activities until the significance of any fossils which may be discovered can be determined by qualified personnel, and such fossils properly handled, if so warranted;

- Any recovered fossil specimens will be curated into the collections of a museum repository acceptable to the land management agencies involved; and

- A final technical report will be submitted following completion of the mitigation program.

\subsubsection{Socioeconomic and Community Resources}

A crew no larger than 20 people is expected to be used in constructing the line. No appreciable effects on local schools, sewers or waste, police or fire protection services, or housing will occur due to construction and operation of the line due to the transmission lines isolation. The only public buildings within $\mathbf{1 0}$ miles of the transmission line are the US and Canadian custom buildings at the Wild Horse Port-of-Entry, and an abandoned military radar site at Section 35 (T35N,R11E).

This project is expected to increase the tax base of Hill County by $\$ 800,000$. Proceeds to Hill County from operation of the line will be passed on to members of the electric cooperative in the form of stabilized rates. Thus, any impacts are positive.

\subsubsection{Transportation and Noise}

Minimal disruption to local farm traffic will occur during construction. Construction along US 232 to the Canadian border will temporarily disrupt traffic, and Montana Department of Transportation highway safety construction measures will be used. 
Transmission lines which are $69-\mathrm{kV}$ and lower generally generate noise levels lower than surrounding ambient noise levels. The isolation of the line relative to humans decreases any safety problems.

\subsubsection{Environmental Justice}

No impacts would occur due to the construction of the line.

\subsubsection{Safety and Electromagnetic Effects}

Typical levels of EMF emitted from a $69-\mathrm{kV}$ transmission line range from 1 to 5 miligauss. At the levels of project loading, EMF levels are expected to be less than 1 miligauss. The proposed $69-\mathrm{kV}$ transmission line will be constructed to meet the requirements of the NESC. Right-of-way shall be obtained to maintain the necessary clearances in accordance with the NESC. Horizontal clearances to the transmission line will be maintained in accordance with the NESC, as well as vertical clearances over objects and roads;

Fences that cross the right-of-way or enter the right-of-way or parallel the line within the right-of-way will be grounded at specified intervals as a safety precaution.

Electrical fields emanating from the transmission line are not expected to induce a large enough voltage on fences that would cause a problem to the public.

Sixty-hertz EMFs will emanate from the line. They will be of very small magnitude in the order of $1 / 1000$ of a gauss or a miligauss (mG). By comparison, the earth's steady state magnetic field is around $\mathbf{5 0 0}$ miligauss. EMF from the largest transmission lines has fields in the 10 miligauss range. Typical levels from $69-\mathrm{kV}$ lines are in the one to five miligauss range. EMF levels from the project line at the projected loading of $7,500 \mathrm{~kW}$ will be very small, below one miligauss, and are not considered a significant source of negative effects.

Studies continue regarding the effects of EMF on health. However, to date, there have been no preclusions with regard to such effects.

The electric and magnetic fields generated from the transmission line are of a very low level. Electric field effects will be mitigated through proper grounding and through other design requirements. Due to the remote location of the line, and the very small magnetic field levels, no appreciable effects due to magnetic fields are anticipated.

Most of the transmission line passes through isolated areas. The only human activity in the area of the transmission line is farming and only one house is located within 100 yards of the transmission line. 


\subsection{Northwestern Route Alternative}

The same impacts are expected with the Northwestern Route Alternative as occur with the proposed Express Route Alternative except for the following sections:

\subsubsection{Wetlands}

The Northwestern Route Alternative alignment would cross ephemeral wetlands located at Section 10 (T36N,R10E) and Sections 24 and 34 (T37N,R10E). Construction and operation of the transmission line will not affect these wetlands as the line will span over them and construction crews will not need to cross over the wetlands.

\subsubsection{Wildlife}

Waterfowl: The Northwestern Route Alternative crossing at the Milk River provides poor quality habitat for waterfowl. Only $15-20$ waterfowl were observed at the crossing during the survey and no significant impacts are expected. However, to decrease the potential for waterfowl collisions with the proposed transmission line, helical wrap markers will be placed on the lines to increase their visibility. Additionally, the shield wire will be removed from the lines in the crossing. A H-frame design was chosen for the crossing to further reduce the potential for waterfowl collisions by placing all three conductors within the same horizontal plane.

\subsubsection{Visuals}

No visual impacts would occur.

\subsubsection{Cultural}

The same conclusions can be reached for JA-3, JA-4, and JA-5. These sites could be eligible for the NRHP under relevant criteria. In addition, the small cluster of five rocks in the north side of the tipi ring on JA-4 will not be impacted by construction. As with the Express Route, an archeologist would be on-site during construction to monitor potential unidentified cultural resources.

\subsection{Cottonwood Route Alternative}

Impacts are the same as the proposed Express Route Alternative except for the following sections:

\subsubsection{Wetlands}

A large assemblage of wetlands would be disturbed in the removal of existing poles and construction of a new $69-\mathrm{kV}$ transmission line at the Milk River. The impacts would be significant. 


\subsubsection{Visual}

No additional visual impacts would occur beyond existing intrusions by the existing line.

\subsection{Summary of Impacts}

Tables 4-3 and 4-4 summarize the relative potential impacts to the environment of the three route alternatives. The least potentially environmentally impactive routes are the Express and Northwestern Alternatives. When combined with economics, landowner preferences, long-term reliability, and maintenance access concerns, plus ease of construction concerns, the preferred route is the Express Alternative.

\begin{tabular}{|c|c|c|c|}
\hline \multicolumn{4}{|c|}{$\begin{array}{l}\text { Table 4-3 } \\
\text { Construction Impacts } \\
\text { Alternative Route Selection Summary }\end{array}$} \\
\hline Potential Impacts & $\begin{array}{l}\text { Express Route } \\
\text { Alternative }\end{array}$ & $\begin{array}{c}\text { Northwestem Route } \\
\text { Alternative }\end{array}$ & $\begin{array}{c}\text { Cottonwood Route } \\
\text { Alternative }\end{array}$ \\
\hline Air Quality & 1 & 1 & 1 \\
\hline Geology \& Soils & 1 & 1 & 1 \\
\hline Surface Water & 0 & 0 & 0 \\
\hline Wetlands & 0 & 0 & 3 \\
\hline Aquatic Ecology & 0 & 0 & 0 \\
\hline Vegetation & 1 & 1 & 1 \\
\hline Wildlife & 2 & 2 & 3 \\
\hline Land Use & 1. & 1 & 1 \\
\hline Visual Resources & 1 & 1 & 1 \\
\hline Cultural Resources & 1 & 1 & 1 \\
\hline $\begin{array}{l}\text { Paleontological } \\
\text { Resources }\end{array}$ & 1 & 1 & 1 \\
\hline Socio Economic & 1 & 1 & 1 \\
\hline Transportation & 1 & 1 & 1 \\
\hline Environmental Justice & 0 & 0 & 0 \\
\hline \multirow[t]{2}{*}{ Safety \& EMF } & 0 & 0 & $\underline{\underline{0}}$ \\
\hline & 11 (preferred) & 11 & 15 \\
\hline
\end{tabular}




\begin{tabular}{|c|c|c|c|}
\hline \multicolumn{4}{|c|}{$\begin{array}{c}\text { Table 4-4 } \\
\text { Operation Impacts } \\
\text { Alternative Route Selection Summary }\end{array}$} \\
\hline Potential Impacts & $\begin{array}{c}\text { Express Route } \\
\text { Alternative }\end{array}$ & $\begin{array}{c}\text { Northwestem Route } \\
\text { Alternative }\end{array}$ & $\begin{array}{l}\text { Cottonwood Route } \\
\text { Alternative }\end{array}$ \\
\hline Air Quality & 0 & 0 & 0 \\
\hline Geology \& Soils & 0 & 0 & 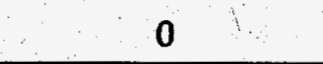 \\
\hline Surface Water & 0 & 0 & 0 \\
\hline Wetlands & 0 & 0 & 0 \\
\hline Aquatic Ecology & 0 & 0 & 0 \\
\hline Vegetation & 1 & 1 & 1 \\
\hline Wildlife & 1 & 1 & 2 \\
\hline Land Use & 1 & 1 & 1 \\
\hline Visual Resources & $1 \ldots$ & 1 & 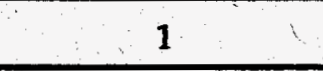 \\
\hline Cultural Resources & 0 & 0 & 0 \\
\hline $\begin{array}{l}\text { Paleontological } \\
\text { Resources }\end{array}$ & 0 & 0 & 0 \\
\hline Socio Economic & 0 & 0 & 0 \\
\hline Transportation & 0 & 0 & 0 \\
\hline $\begin{array}{l}\text { Environmental } \\
\text { Justice }\end{array}$ & 0 & 0 & 0 \\
\hline Safety \& EMF & 1 & 1 . & 1 \\
\hline 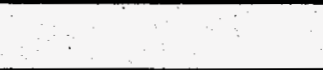 & 5 (preferred) & 5 & 6 \\
\hline $0=$ No Impacts $\quad 1=$ Low & $2=$ Medium Impacts & 3=High Impacts & \\
\hline
\end{tabular}


Access road - A means of vehicular travel, usually from a public road to a transmission line corridor or other associated facility. Generally, easements are acquired on existing roads. If no suitable road exists, new roads are constructed.

Alignment - The specific, surveyed location or route of a transmission centerline. It is tied to recorded monuments so that its exact location can be determined in relation to private and public property ownership.

Base Load - The minimum load in a power system over a given period of time.

Cable - A conductor with insulation, a stranded conductor with or without insulation and other covering (single-conductor cable), or a combination of conductors insulated from one another (multiple-conductor cable).

Capacity - The load for which a generating unit, generating station, or other electrical apparatus is rated either by the use or the manufacturer. Sometimes, the term capacity is used as a synonym for "capability."

Conductor - A material, usually in the form of a wire, cable, or bus bar, suitable for carrying an electric current.

Coulee - A dry wash or gully.

Corridor - A linear strip of land of variable width, which accommodates or is expected to accommodate one or more utility facilities such as transmission lines.

Easement - A limited right to do certain specified actions on another's land. For these projects, the rights to be acquired include among other. right to construct, operate and maintain a transmission line; right to use or construct and maintain access roads.

Floodplain - Level land that may be submerged by floodwaters.

Kilovolt (kV) $-1,000$ volts.

Line loss - the power dissipated (lost) in a transmission line expressed in watts; conductor resistance and other factors lead to power being lost in transmission between one point and another.

Load - The amount of electricity required (demand) at any instant or over a period of time. 
Magnetic field - a region of space in which there is an appreciable magnetic force. Near transmission lines, a magnetic field is created by the flow of current in the circuit.

Mitigation - Any measure which avoids, minimizes, or rectifies environmental impacts of the proposed action or alternatives. Mitigation also includes measures which compensate for the impact by providing substitute resources or environments.

Particulate emissions - Solid (though sometimes microscopic) air pollutants such as dust and fine organic particles that are emitted by various sources or suspended by wind.

Right-of-way - A type of easement consisting of the privilege to pass over another's land. A right-of-way is an accurately located strip of land with defined width, point of beginning and point of ending within which the user has authority to construct and maintain a utility facility, such as transmission lines, as authorized by a written agreement.

Riparian - Of, adjacent to, or living on the bank of a river or stream (or, sometimes, a lake or pond).

Route - A strip of land of varying width in which a transmission line right-of-way could be located.

Visual impact - A change in the perception of the visual quality of a landscape resulting from a visible change or modification in the landscape. Visual impact can result from natural ecological changes, such as erosion, development activities, such as buildings or transmission lines, and land management activities such as timber harvesting and fire breaks.

Visual sensitivity - A measure of people's concern for the scenic quality of landscape. With the BLM's VRM System, regional and individual attitudes toward the landscape are measured by determining use volume and user or public reaction.

Voltage - The effective root-mean-square (rms) potential difference between any two conductors or between a conductor and ground. Voltages are expressed in nominal values. The nominal voltage of a system or circuit is the value assigned to a system or circuit of a given voltage class for the purpose of convenient designation. The operating voltage of the system may vary above or below this value. 
Avian Power Line Interaction Committee. 1996. Suggested Practices for Raptor Protection on Power Lines: The State of the Art in 1996. Edison Electric Institute/Raptor Research Foundation Washington, D.C. 80 pp.

Case, G.R. 1978. A new selachian fauna from the Judith River Formation (Campanian) of Montana. Palaeontographica, v. 160, p. 176-205.

- 1979. Additional fish records from the Judith River Formation (Campanian) of Montana, Geobiosv. 12, p. 223-233.

Clemens, E.A., Lillegraven, J. A., Lindsay, E. H., and Simpson, G. G. 1979. Where, When and What - A survey of known Mesozoic mammal distribution: in Lillegraven, Kielan-Jaworowska and Clemens eds., Mesozoic Mammals The First Two Thirds of Mammalian History; University of California Press, Chapter 2, p. 7-58

Clouse, V. R., et al. 1993. Eggs and embryos from the Late Cretaceous (Campanian) Judith River Formation of north-central Montana. Journal of Vertebrate Paleontology, Vol. 13, p. 31.

Clouse, V: R. 1995. Paleogeography of an extensive dinosaur nesting horizon in the Judith River Formation of north-central Montana. Abstracts with Programs - Geological Society of America. v. 27, p. 6.

Ehrlich, Paul R., David S. Dobkin, and Darryl Wheye. 1988. The Birder's Handbook. A Field Guide to the Natural History of North American Birds. New York: Simon and Schuster, Inc.

Ethnoscience. 1991. Pre-inventory report containing a revised historic properties identification plan and management plan for Cultural Resources on the proposed Altamont Gas Pipeline Project in Montana and Wyoming.

1992. Inventory and evaluation report for Cultural Resources on the proposed Altamont Gas Pipeline Project, Montana segmen, 186 p.

- 1995. Inventory and recommended treatment report for paleontologic localities on the proposed Express Pipeline Project: Montana Segment, 18 p.

Express Pipeline, Inc. 1993. Express Pipeline Information Report, Express Pipeline, Inc. 
Express Pipeline, Inc. 1995. Express Pipeline Information Report, Canada Oil Pipeline Draft Environmental Impact Statement. Express Pipeline, Inc.

Galton, P. M. and Sues, H-D. 1983. New data on pachycephalosaurid dinosaurs (Re,otilia: Ornithischia) from North America: Canadian Journal of Earth Sciences, v. 20, no. 3, p. 462-472.

Hay, O. P. 1904. On two new species of turtles from the Judith River beds of Montana: Carnegie Museum Annals, v. 3, p. 172-182.

Holland, W. J. 1909. Deinosuchus hatcheri, a new genus and species of crocodile from the Judith River beds of Montana: Carnegie Museum Annals, v. 6, p. 281-294.

Horner, J. R. 1988. A new hadrosaur (Reptilia, Ornithischia) from the Upper Cretaceous Judith River Formation of Montana: Journal Vertebrate Paleontology, v. 8, no. 3, p. 314-321.

1993. The Mesozoic Terrestrial ecosystems of Montana. in Hunter, L. D. V., ed. 1993. Energy and Mineral Resources of Central Montana.,p. 153-162.

Keyser, James D. 1979. Late Prehistoric Period Bison Procurement on the Milk River in North-Central Montana. Archaeology in Montana. 20(1):1-241. Bozeman, Montana.

Knowiton, F. H. 1900. Flora of the Montana formation: Bulletin U. S. Geological Survey, v. 163, p. $1-118$.

1905. Fossil plants of the Judith River beds: Bulletin U. S. Geological Survey, v. 257, p. $129-155$.

1915. Description of a new fossil fern from the Judith River Formation of Montana (Dryopteris lloydii: Torreya, v. 1 S, p. 67-70.

Kroeber, Alfred L. 1939. Cultural and Natural Areas of Native North America. University of California Publications in American Archaeology and Ethnology 38. Berkeley, California.

Lull, R. S. and Wright, N. E. 1942 Hadrosaurian dinosaurs of North America: Geological Society of America, Special Paper no. 40, p.

Marsh, O.C. 1888. A new family of horned dinosaurs from the Cretaceous. American Journal Science, v. 36, p. 447-478. 
- 1889. Notice of new American dinosaurs: American Journal Science, v. 37, pp. 331-336.

1890. Description of new dinosaurian reptiles: American Journal Science, v. 39, pp. 81-86.

- 1893. A new Cretaceous bird allied to Hesperornis: American Journal Science, v. 45, pp. $81-82$.

Malone, M.P. and R.B. Roeder. 1976. Montana: A History of Two Centuries. University of Washington Press, Seattle, Washington.

Meek, F. B. 1876. A report on the invertebrate Cretaceous and Tertiary fossils of the upper Missouri country: Reports of the U.S.Geological Survey, v. 9, p. 1-629.

Montana Natural Heritage Program. 1996. Element Occurrence Records for Hill County, Montana. May 1, 1996.

Rogers, R. R. 1993. Marine facies of the Judith River Formation (Campanian) in the type area, north-central Montana." Hunter, L. D. V., ed. Energy and Mineral Resources of Central Montana., p. 61-69.

Rogers, R. R., et al. 1995. Late Cretaceous vertebrates by the sea; diverse nonmarine assemblages in coastal facies of the Campanian Judith River Formation, north-central Montana. Abstracts with Programs - Geological Society of America. v. 27, p. 52.

Ruebelmann, George N. 1983. An Overview of the Archaeology and Prehistory of the Bureau of Land Management, Lewistown District, Montana. Archaeology in Montana. 24(3):1-241.

Sahni, A. 1972. The vertebrate fauna of the Judith River Formation, Montana: Bulletin American Museum Natural History v. 147, p.

Stanton, T. W. and Hatcher, J. B. 1905. Geology and paleontology of the Judith River beds: Bulletin U. S. Geological Survey, v. 257, p. 1-128.

Sturtevant, W.C. 1986. Handbook of North American Indians: Volume 11, Great Basin. Smithsonian Institution; Washington, D.C.

U.S. Bureau of Land Management. 1995. Express Crude Oil Pipeline Draft Environmental Impact Statement.

U.S. Fish and Wildlife Service. 1996. Letter dated June 11, 1996, from Kemper McMaster. 
Winterfeld, G. F. 1996. Paleontologic Resource evaluation Express pipeline project Montana, prepared for Ethnoscience, Billings, MT by Erathem-Vanir Geological Consultants, Pocatello, ID, 71 pages with Confidential Appendix.

Jensen, Peter. 1996. Archaeological Inventory Survey, Proposed Wild Horse 69-kV Electrical Transmission Line. Jensen \& Associates. 


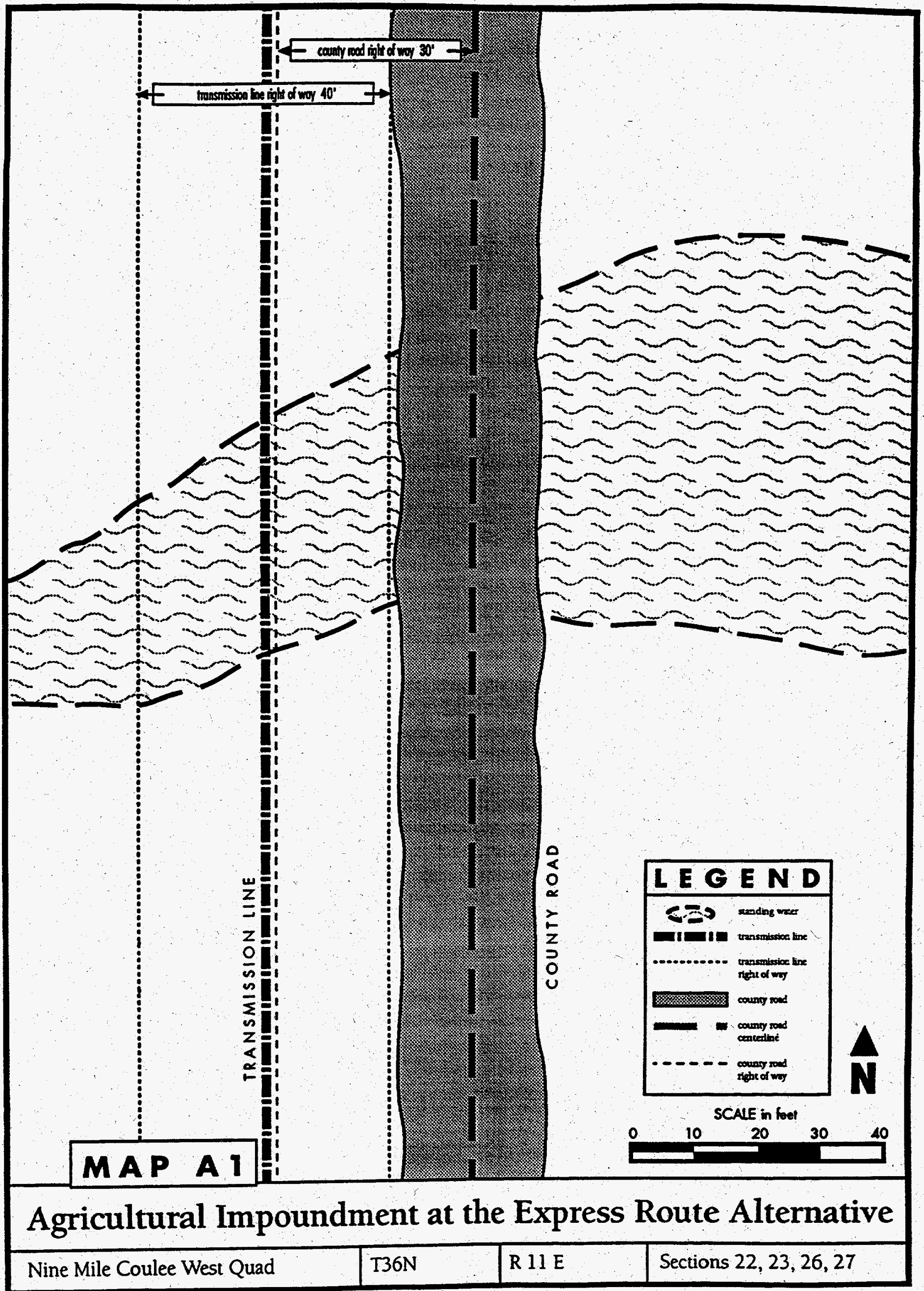




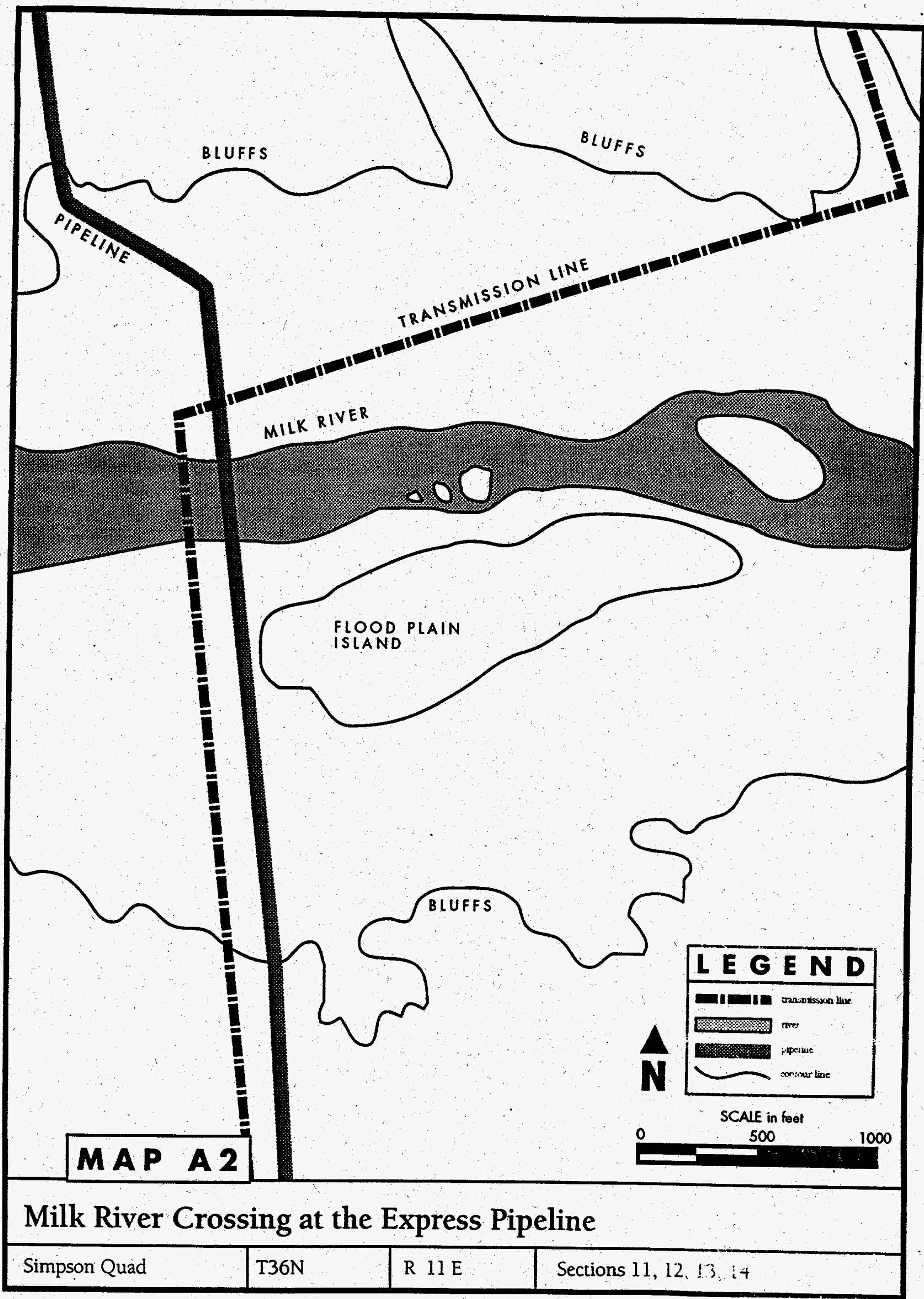




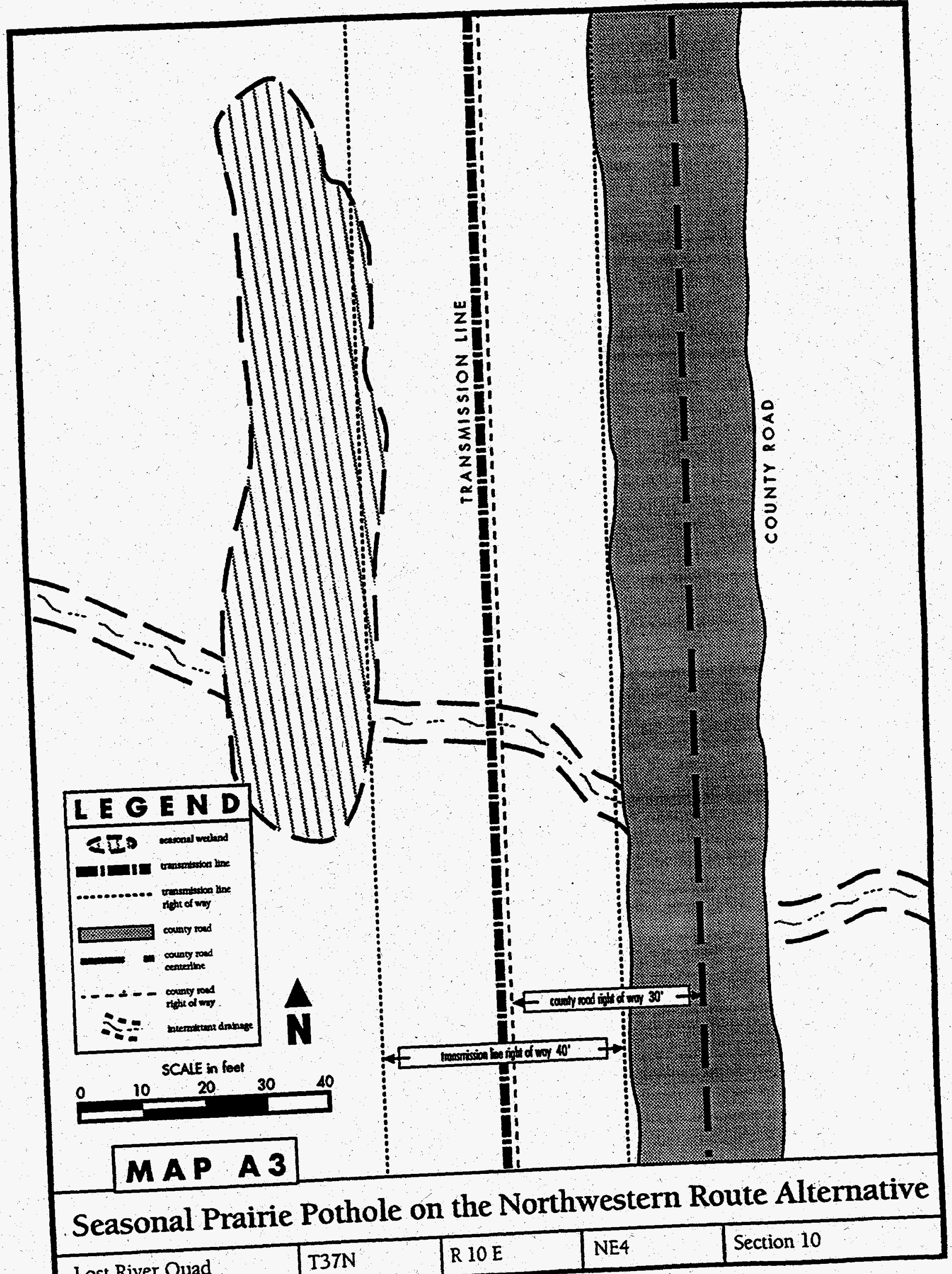




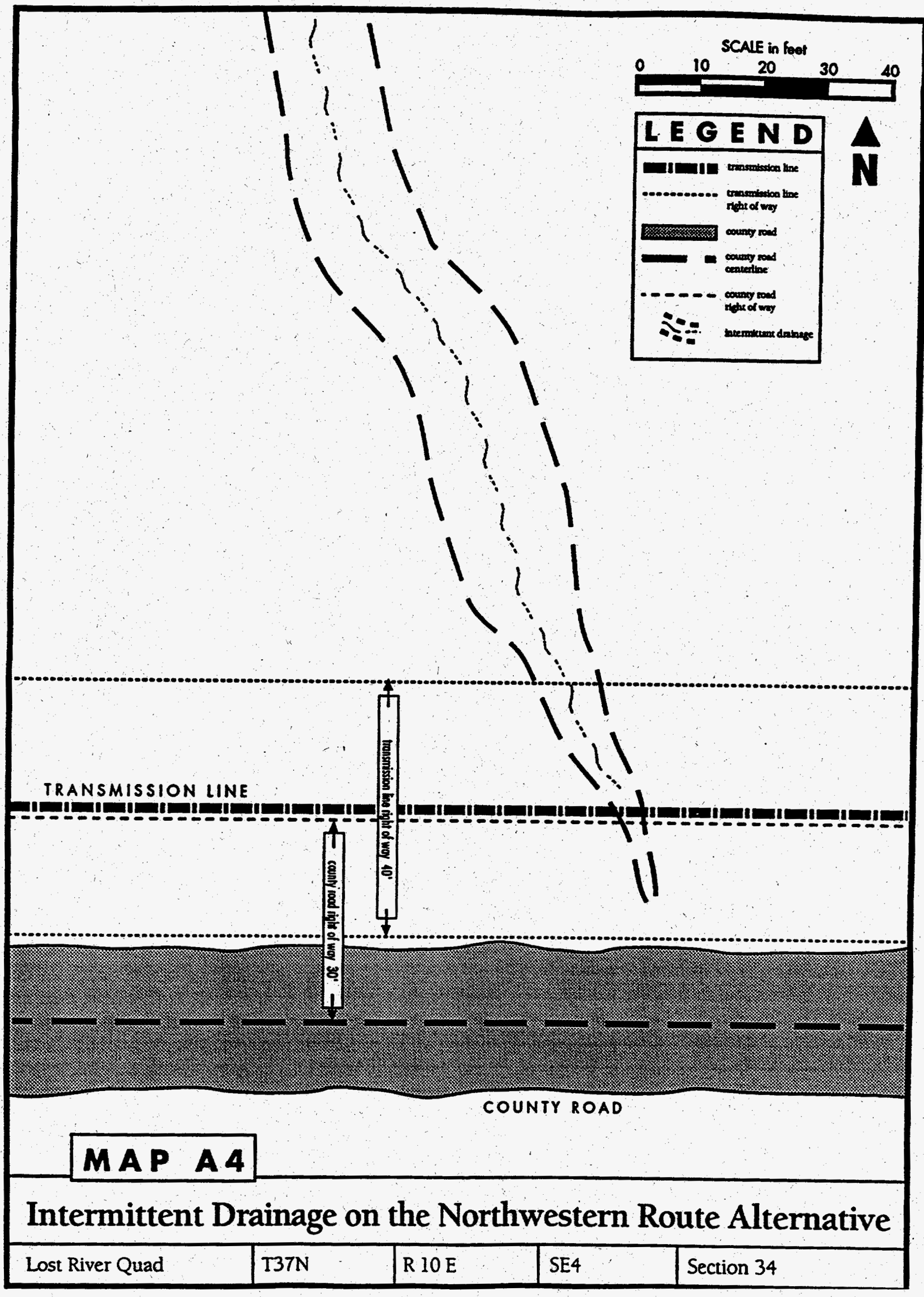




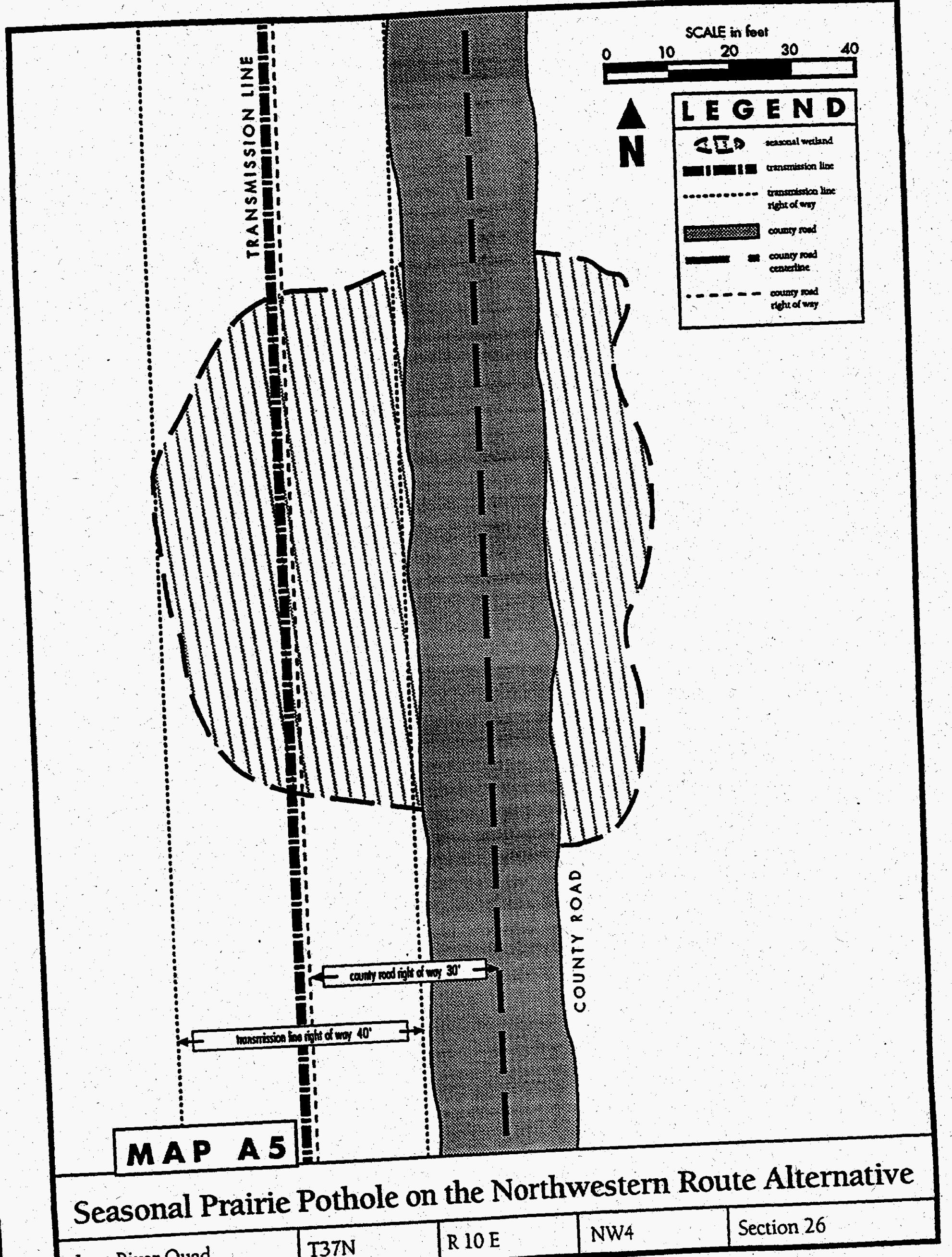




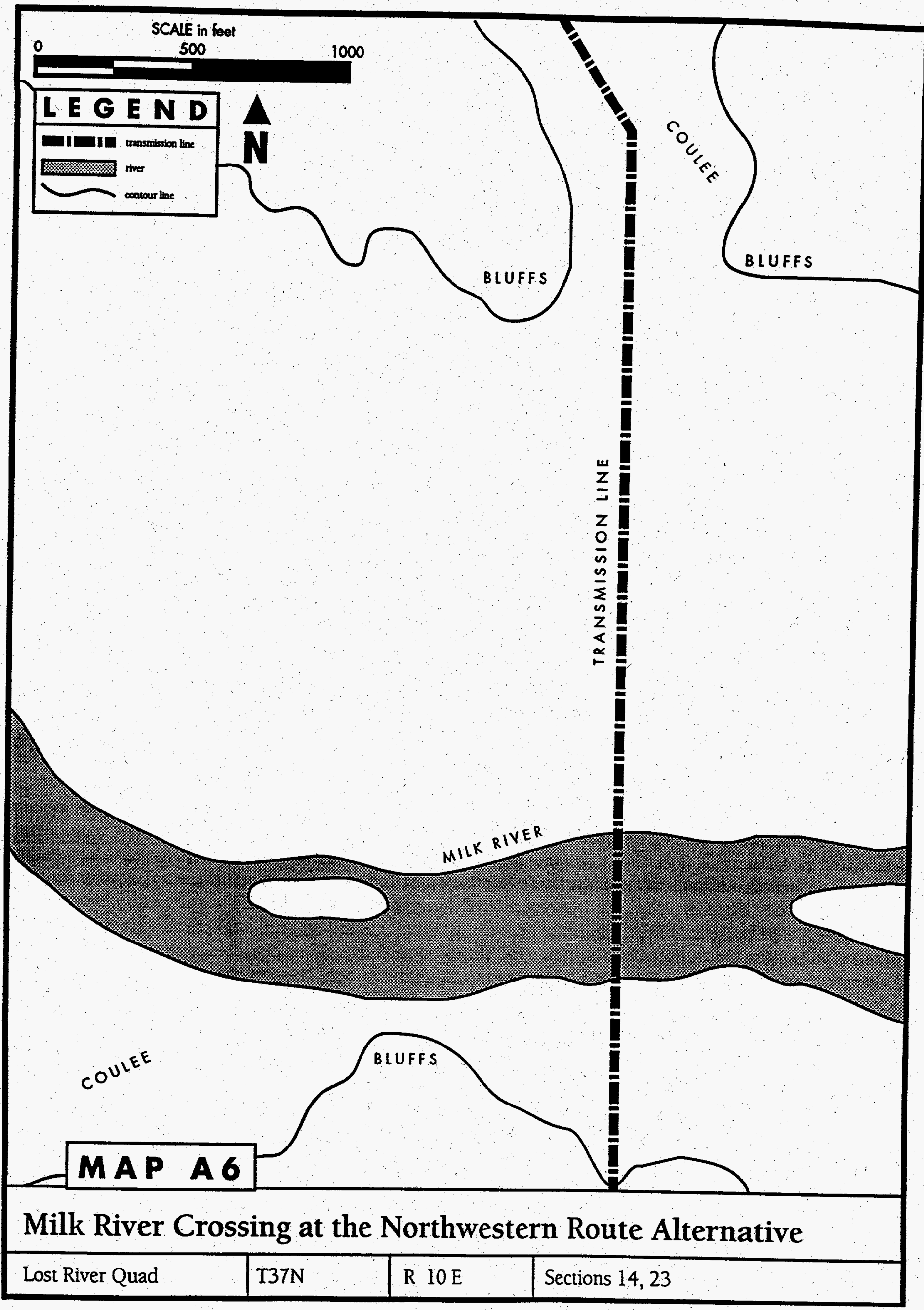




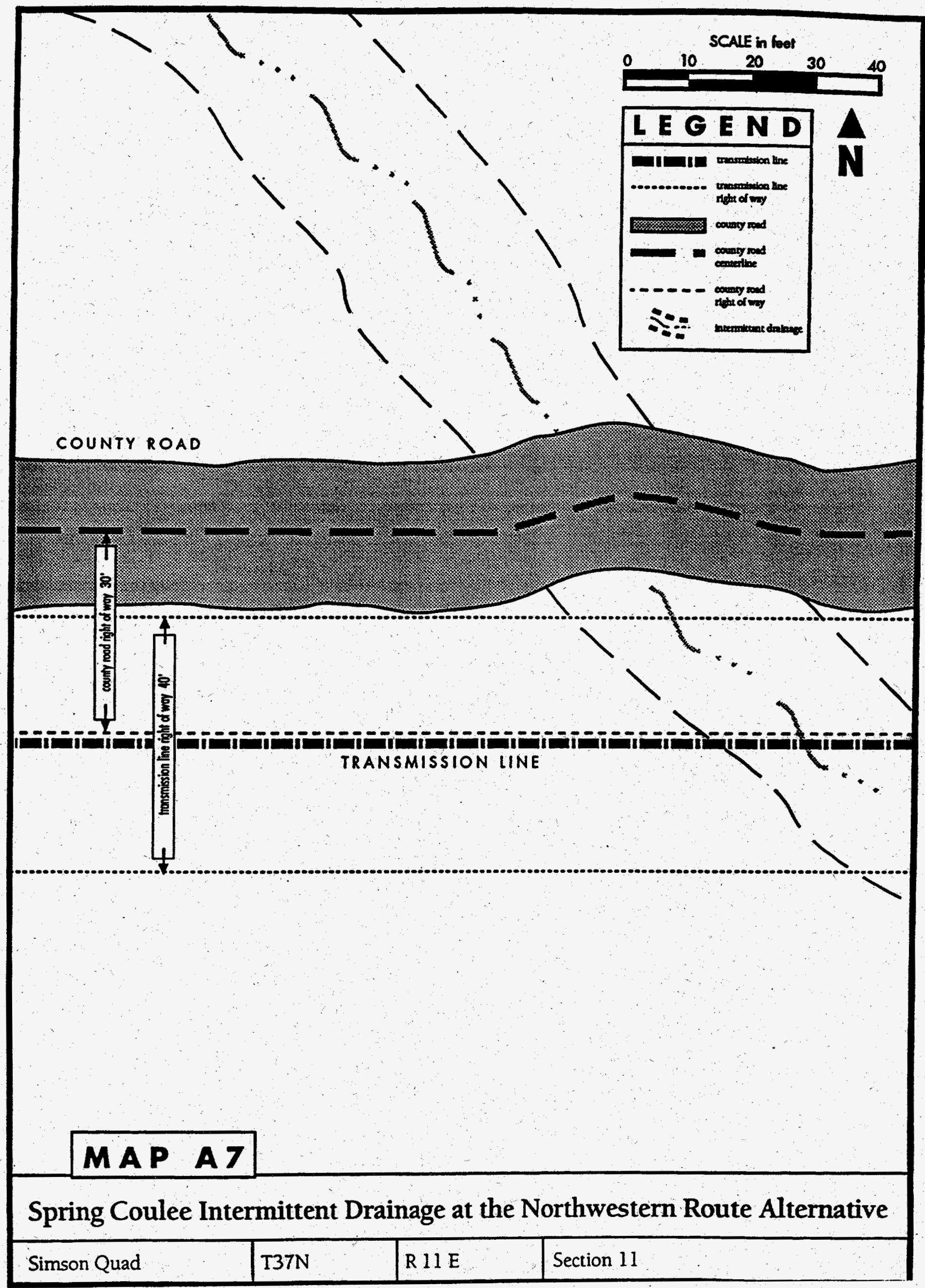




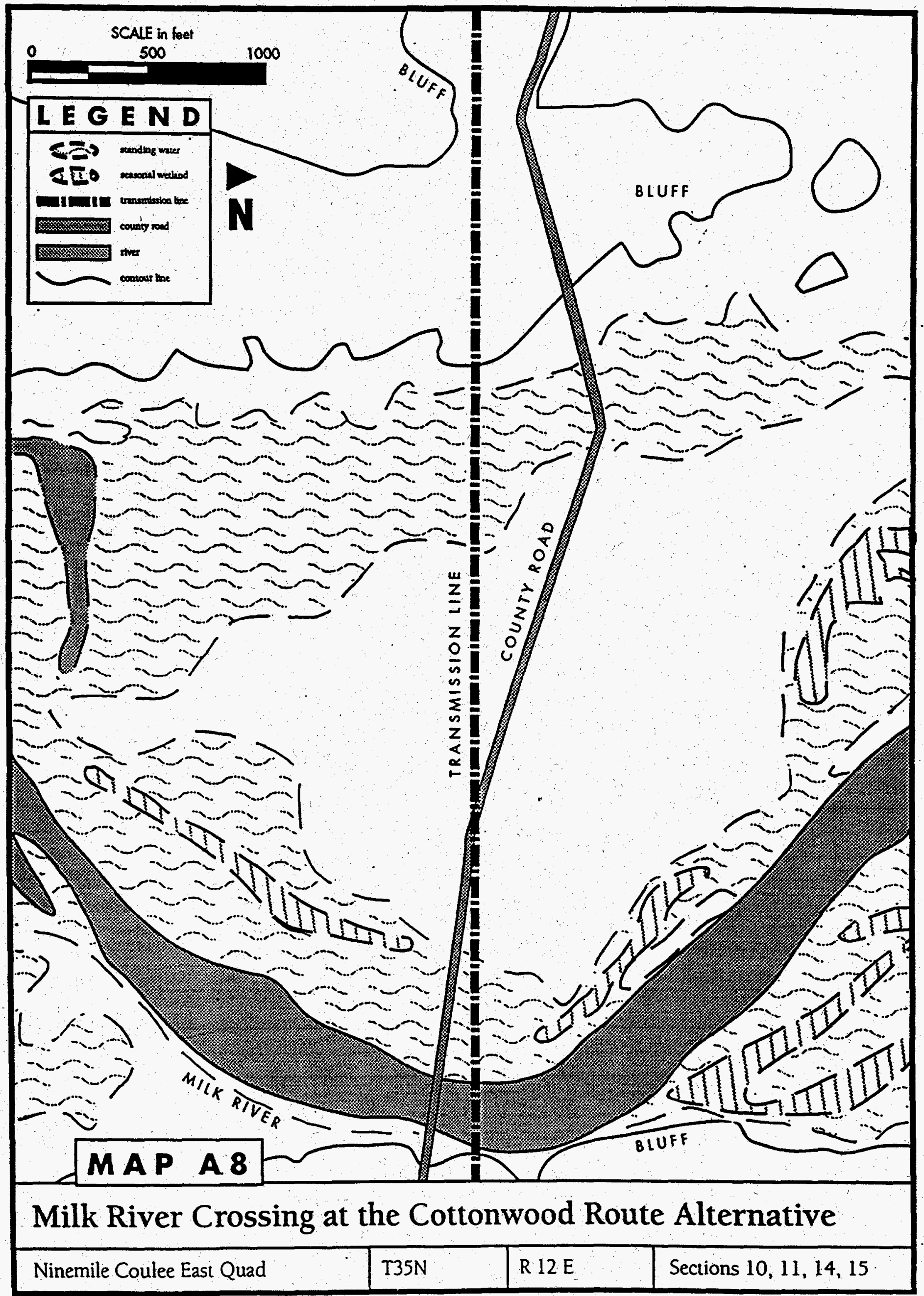


Plant Species Encountered along the

Express Route Alternative of the

Wild Horse 69-kV Transmission Line

\begin{tabular}{||l|l|}
\hline \multicolumn{1}{|c|}{ Scientific Name } & \\
\hline Achillea millefolium & yarrow \\
\hline Agropyron cristata & crested wheatgrass \\
\hline Agropyron intermedium & intermediate wheatgrass \\
\hline Agrostis scabra & bentgrass \\
\hline Agrostis stolonifera & red top \\
\hline Allium textile & wild onion \\
\hline Antennaria paroifolia & pussytoes \\
\hline Apocynum androsaemifolium & dogbane \\
\hline Artemisia cana & silver sage \\
\hline Artemisia frigida & fringed sage \\
\hline Astragalus agrestis & locoweed \\
\hline Astragalus crassicarpus & prairie plum \\
\hline Astragalus eucosmus & milkvetch \\
\hline Astragalus gilviflorus & plains orophaca \\
\hline Astragalus lotiflorus & locoweed \\
\hline Astragalus pectinatus & tine-leaved locoweed \\
\hline Astragalus spatulatus & draba milkvetch \\
\hline Atriplex canescens & saltbrush \\
\hline Atriplex gardneri & Gardner's saltbush \\
\hline Avena fatua & wild oat \\
\hline Beckmannia syzigachne & beckmannia \\
\hline Bouteloua gracilis & blue grama \\
\hline
\end{tabular}




\begin{tabular}{||l|l|}
\hline \multicolumn{1}{|c|}{ Scientific Name } & \multicolumn{1}{c|}{ Common Name } \\
\hline Bromus inermis & smooth brome \\
\hline Bromus japonicus & Japanese brome \\
\hline Calamovilfa longifolia & prairie sandweed \\
\hline Calochortus nuttallii & Nuttall's Mariposa lily \\
\hline Caragana arborescens & Siberian pea \\
\hline Carex douglasii & Douglas' sedge \\
\hline Carex lanuginosa & woolly sedge \\
\hline Carex nebrascensis & Nebraska sedge \\
\hline Carex stenophylla & sedge \\
\hline Ceratoides lanatum & winterfat \\
\hline Chenopodium gigantium & goosefoot \\
\hline Chrysopsis villosa & hoary aster \\
\hline Chrysothamnus nauseosus & rabbitbrush \\
\hline Cirsium aroense & Canada thistle \\
\hline Cirsium undulatum & wavy-leaved thistle \\
\hline Collomia linearis & collomia \\
\hline Comandra umbellata & bastard toad flax \\
\hline Conyza canadensis & conyza \\
\hline Cryptantha celosioides & miner's candle \\
\hline Dalea candida & white prairie clover \\
\hline Descurainia pinnata & tansy mustard \\
\hline Distichlis stricta & saltgrass \\
\hline Elaeagnus angustifolia & Russian olive \\
\hline Eleocharis palustris & spikerush \\
\hline Elymus sp. & ryegrass \\
\hline Elymus glaucus & wild rye \\
\hline
\end{tabular}




\begin{tabular}{|l|l|}
\hline \multicolumn{1}{|c|}{ Scientific Name } & \multicolumn{1}{c|}{ Common Name } \\
\hline Elymus smithii & western wheatgrass \\
\hline Elymus spicatus & bluebunch wheatgrass \\
\hline Equisetum hyemale & horsetail \\
\hline Erigeron divergens & fleabane \\
\hline Eriogonum flaoum & yellow buckwheat \\
\hline Euphorbia serpyllifolia & spurge \\
\hline Gaillardia aristata & blanketflower \\
\hline Gaura coccinea & gaura \\
\hline Glycyrrhiza lepidota & wild licorice \\
\hline Grindelia squarrosa & gumweed \\
\hline Gutierrezia sarothrae & matchweed \\
\hline Helianthus annus & sunflower \\
\hline Hordeum jubatum & foxtail barley \\
\hline Hymenoxys acaulis & stemless hymenoxys \\
\hline Hyssopus officinalis & hyssop \\
\hline Juncus balticus & baltic rush \\
\hline Kochia scoparia & kochia \\
\hline Koeleria cristata & June grass \\
\hline Koeleria macrantha & June grass \\
\hline Lactuca serriola & prickly lettuce \\
\hline Lepidium densiflorum & peppergrass \\
\hline Linum rigida & yellow flax \\
\hline Lomatium dissectum & fern-leaved desert parsley \\
\hline Machaeranthera canescens & hoary aster \\
\hline Machaeranthera grindelioides & aster \\
\hline Medicago satioa & alfalfa \\
\hline
\end{tabular}




\begin{tabular}{|l|l|}
\hline \multicolumn{1}{|c|}{ Scientific Name } & \multicolumn{1}{|c|}{ Common Name } \\
\hline Melilotus officinalis & yellow sweet clover \\
\hline Mentha arvensis & mint \\
\hline Microsteris gracilis & microsteris \\
\hline Oenothera sp. & primrose \\
\hline Opuntia polyacantha & Missouri cholla \\
\hline Oxytropis sericeas & silky crazyweed \\
\hline Paronychia sessiliflora & paronychia \\
\hline Penstemon sp. & penstemon \\
\hline Penstemon eriantherus & hairy penstemon \\
\hline Penstemon gracilis & slender penstemon \\
\hline Phlox hoodii & Hood's phlox \\
\hline Plantago patagonica & Patagonia plantain \\
\hline Poa palustris & bluegrass \\
\hline Poa pratensis & Kentucky bluegrass \\
\hline Poa secunda & bluegrass \\
\hline Polygonum achoreum & knotweed \\
\hline Polygonum aviculare & knotweed \\
\hline Polygonum conooloulus & vining buckwheat \\
\hline Populus deltoides & Great Plains cottonwood \\
\hline Potentilla anserina & potentilla \\
\hline Rosa arkansana & Arkansas rose \\
\hline Rumex amphibium & amphibious sorrel \\
\hline Rumex crispus & crisp-leaved sorrel \\
\hline Rumex salicifolius & willow-leaved sorrel \\
\hline Salix amygdaloides & peach-leaved willow \\
\hline Salix exigua & sandbar willow \\
\hline
\end{tabular}




\begin{tabular}{|l|l|}
\hline \multicolumn{1}{|c|}{ Scientific Name } & \\
\hline Salix lasiandra & willow \\
\hline Salsola iberica & Russian thistle \\
\hline Sarcobatus vermiculatus & greasewood \\
\hline Senecio canus & groundsel \\
\hline Sisymbrium loeselii & tumble mustard \\
\hline Spartina pectinata & cordgrass \\
\hline Sphaeralcea coccinea & desert mallow \\
\hline Stachys palustris & hedgenettle \\
\hline Stipa comata & needle and thread grass \\
\hline Stipa viridula & green needle and thread grass \\
\hline Suaeda calceoliformis & sea blite \\
\hline Symphoricarpos occidentalis & western snowberry \\
\hline Taraxacum officinale & dandelion \\
\hline Thelesperma marginatum & thelesperma \\
\hline Thermopsis rhombifolia & yellow pea \\
\hline Thlaspi arvense & pennycress \\
\hline Tragopogon dubius & goatsbeard \\
\hline Verbena bracteata & prostrate verbena \\
\hline Vicia americana & vetch \\
\hline Zigadenus venenosus & death camas \\
\hline
\end{tabular}


Plant Species Encountered along the Northwestem Route Alternative of the Wild Horse 69-kV Transmission Line

\begin{tabular}{|l|l|}
\hline \multicolumn{1}{|c|}{ Scientific Name } & \\
\hline Achillea millefolium & yarrow \\
\hline Agropyron intermedium & intermediate wheatgrass \\
\hline Agrostis scabra & bentgrass \\
\hline Allium textile & wild onion \\
\hline Alyssum desertorum & alyssum \\
\hline Antennaria paroifolia & pussytoes \\
\hline Apocynum androsaemifolium & dogbane \\
\hline Arabis holboellii & Holboell's rockcress \\
\hline Artemisia cana & silver sage \\
\hline Artemisia campestris & field sage \\
\hline Artemisia frigida & fringed sage \\
\hline Artemisia ludooiciana & sage \\
\hline Asclepias viridiflora & milkweed \\
\hline Astragalus adsurgens & locoweed \\
\hline Astragalus crassicarpus & prairie plum \\
\hline Astragalus gilviflorus & plains orophaca \\
\hline Astragalus lotiflorus & locoweed \\
\hline Astragalus miser & locoweed \\
\hline Astragalus pectinatus & tine-leaved locoweed \\
\hline Astragalus spatulatus & draba milkvetch \\
\hline Atriplex gardneri & Gardner's saltbush \\
\hline Bouteloua gracilis & blue grama \\
\hline Bromus japonicus & Japanese brome \\
\hline Calamovilfa longifolia & prairie sandweed \\
\hline
\end{tabular}




\begin{tabular}{|l|l|}
\hline \multicolumn{1}{|c|}{ Scientific Name } & \\
\hline Camelina satioa & false flax \\
\hline Campanula rotundifolia & harebell \\
\hline Carex lanuginosa & woolly sedge \\
\hline Carex stenophylla & sedge \\
\hline Ceratoides lanatum & winterfat \\
\hline Chenopodium album & goosefoot \\
\hline Chrysothamnus nauseosus & rabbitbrush \\
\hline Cirsium undulatum & wavy-leaved thistle \\
\hline Collomia linearis & collomia \\
\hline Comandra umbellata & bastard toad flax \\
\hline Conyza canadensis & conyza \\
\hline Cryptantha celosioides & miner's candle \\
\hline Dalea purpurea & purple prairie clover \\
\hline Descurainia pinnata & tansy mustard \\
\hline Distichlis stricta & saltgrass \\
\hline Elaeagnus angustifolia & Russian olive \\
\hline Eleocharis palustris & spikerush \\
\hline Elymus glaucus & wild rye \\
\hline Equisetum arvense & field horsetail \\
\hline Equisetum hyemale & horsetail \\
\hline Erigeron caespitosus & fleabane \\
\hline Erigeron divergens & fleabane \\
\hline Erigeron ochroleucus & fleabane \\
\hline Erysimum asperum & wallflower \\
\hline Euphorbia serpyllifolia & spurge \\
\hline Festuca scabrella & rough fescue \\
\hline
\end{tabular}




\begin{tabular}{|l|l|}
\hline \multicolumn{1}{|c|}{ Scientific Name } & \\
\hline Gaillardia aristata & blanketlower \\
\hline Geum triflorum & prairie smoke \\
\hline Glycyrrhiza lepidota & wild licorice \\
\hline Gnaphalium palustre & cudweed \\
\hline Grindelia squarrosa & gumweed \\
\hline Gutierrezia sarothrae & matchweed \\
\hline Helianthus rigidus & rigid sunflower \\
\hline Heterotheca villosa & golden hairy aster \\
\hline Hordeum brachyantherum & barley \\
\hline Hordeum jubatum & foxtail barley \\
\hline Hymenoxys acaulis & stemless hymenoxys \\
\hline Iva axillaris & poverty weed \\
\hline Juncus balticus & baltic rush \\
\hline Juniperus horizontalis & horizontal juniper \\
\hline Kochia scoparia & kochia \\
\hline Koeleria macrantha & June grass \\
\hline Lactuca serriola & prickly lettuce \\
\hline Lappula redowskii & stickseed \\
\hline Liatris punctata & gayfeather \\
\hline Linum australe & yellow flax \\
\hline Linum lewisii & blue flax \\
\hline Linum rigida & yellow flax \\
\hline Lithospernum ruderale & puccoon \\
\hline Lomatium dissectum & fern-leaved desert parsley \\
\hline Lupinus pusillus & annual lupine \\
\hline Machaeranthera grindelioides & aster \\
\hline
\end{tabular}




\begin{tabular}{|l|l|}
\hline \multicolumn{1}{|c|}{ Scientific Name } & Common Name \\
\hline Machaeranthera pinnatifida & pinnate machaeranthera \\
\hline Medicago sativa & alfalfa \\
\hline Melilotus officinalis & yellow sweet clover \\
\hline Navarettia intertexta & navarettia \\
\hline Oenothera hookeri & Hooker's primrose \\
\hline Opuntia polyacantha & Missouri cholla \\
\hline Orthocarpus luteus & owl's clover \\
\hline Oryzopsis hymenoides & Indian rice grass \\
\hline Oxytropis lambertii & crazyweed \\
\hline Oxytropis sericeas & silky crazyweed \\
\hline Paronychia sessiliflora & paronychia \\
\hline Penstemon eriantherus & hairy penstemon \\
\hline Plantago major & plantain \\
\hline Plantago patagonica & Patagonia plantain \\
\hline Poa pratensis & Kentucky bluegrass \\
\hline Polygonum aviculare & knotweed \\
\hline Polygonum convolvulus & vining buckwheat \\
\hline Potentilla anserina & potentilla \\
\hline Puccinellia nuttalliana & puccinellia \\
\hline Ratibida columnifera & coneflower \\
\hline Rhus trilobata & skunkbush \\
\hline Rosa arkansana & Arkansas rose \\
\hline Rumex crispus & crisp-leaved sorrel \\
\hline Salix amygdaloides & peach-leaved willow \\
\hline Salix exigua & sandbar willow \\
\hline Salsola iberica & Russian thistle \\
\hline
\end{tabular}




\begin{tabular}{|l|l|}
\hline \multicolumn{1}{|c|}{ Scientific Name } & \multicolumn{1}{c|}{ Common Name } \\
\hline Sarcobatus vermiculatus & greasewood \\
\hline Scirpus acutus & bulrush \\
\hline Senecio canus & groundsel \\
\hline Shepherdia argentea & buffaloberry \\
\hline Solidago missouriensis & Missouri goldenrod \\
\hline Spartina pectinata & cordgrass \\
\hline Sphaeralcea coccinea & desert mallow \\
\hline Stachys palustris & hedgenettle \\
\hline Stephanomeria tenuifolia & skeletonweed \\
\hline Stipa comata & needle and thread grass \\
\hline Stipa viridula & green needle and thread grass \\
\hline Suaeda calceoliformis & sea blite \\
\hline Symphoricarpos occidentalis & western snowberry \\
\hline Thelesperma marginatum & thelesperma \\
\hline Thermopsis rhombifolia & yellow pea \\
\hline Tragopogon dubius & goatsbeard \\
\hline Veronica peregrina & veronica \\
\hline Vicia americana & vetch \\
\hline Zigadenus venenosus & death camas \\
\hline
\end{tabular}


Wildlife Species Encountered along the Express Route Alternative

\begin{tabular}{|c|c|}
\hline Scientific Name & Common Name \\
\hline \multicolumn{2}{|l|}{ Birds } \\
\hline Agelaius phoeniceus & red-winged blackbird \\
\hline Anas platyrhynchos & mallard \\
\hline Anas strepera & gadwall \\
\hline Asio flammeus & shorteared owl \\
\hline Calamospiza melanocorys & lark bunting \\
\hline Charadrius vociferus & killdeer \\
\hline Circus cyaneus & northern harrier \\
\hline Corous brachyrhynchos & American crow \\
\hline Eremophila alpestris & horned lark \\
\hline Euphagus cyanocephalus & Brewer's blackbird \\
\hline Falco sparverius & American kestrel \\
\hline Hirundo pyrrhonota & cliff swallow \\
\hline Hirundo rustica & barn swallow \\
\hline Lanius ludovicianus & loggerhead shrike \\
\hline Melospiza melodia & song sparrow \\
\hline Molothrus ater & brown-headed cowbird \\
\hline Phalacrocorax auritus & double-crested cormorant \\
\hline Pooecetes gramineus & vesper sparrow \\
\hline Quiscalus quiscula & common grackle \\
\hline Sturnella neglecta. & western meadowlark \\
\hline Tachycineta thalassina & violet-green swallow \\
\hline Turdus migratorius & American robin \\
\hline Tyrannus tyrannus & eastern kingbird \\
\hline Zenaida macroura & mourning dove \\
\hline \multicolumn{2}{|l|}{ Mammals } \\
\hline Lepus tozonsendi & white-tailed jackrabbit \\
\hline
\end{tabular}


Wildlife Species Encountered along the Northwestern Route Alternative

\begin{tabular}{|l|l|}
\hline \multicolumn{1}{|c|}{ Scientific Name } & \multicolumn{1}{|c|}{ Common Name } \\
\hline Reptiles & \\
\hline Crotalus viridis & western rattlesnake \\
\hline Birds & killdeer \\
\hline Charadrius vociferus & northern harrier \\
\hline Circus cyaneus & horned lark \\
\hline Eremophila alpestris & ring-necked pheasant \\
\hline Phasianus colchicus & vesper sparrow \\
\hline Pooecetes gramineus & common grackle \\
\hline Quiscalus quiscula & western meadowlark \\
\hline Sturnella neglecta & western kingbird \\
\hline Tyrannus verticalis & mourning dove \\
\hline Zenaida macroura & \\
\hline Mammals & mule deer \\
\hline Odocoileus hemionus & \\
\hline
\end{tabular}




\begin{tabular}{|c|c|c|}
\hline \multicolumn{3}{|c|}{ Required Permits/Approval Summary } \\
\hline Agency & $\begin{array}{l}\text { Permit or Approval } \\
\text { Needed }\end{array}$ & Ruling and Date Issued \\
\hline $\begin{array}{l}\text { International Boundary } \\
\text { Commission }\end{array}$ & $\begin{array}{l}\text { Authorization to } \\
\text { construct, install, operate } \\
\text { and maintain }\end{array}$ & Pending \\
\hline US BOR & $\begin{array}{l}\text { Right-of-Way and/or } \\
\text { crossing permit }\end{array}$ & Pending \\
\hline US COE & $\begin{array}{l}\text { Section } 404 \text {, Clean Water } \\
\text { Act }\end{array}$ & $\begin{array}{l}\text { Issued ruling of no } \\
\text { permit required, } 9 / 16 / 96\end{array}$ \\
\hline US FWS & $\begin{array}{l}\text { Threatened and } \\
\text { Endangered Species }\end{array}$ & $\begin{array}{l}\text { Mitigation Condition } \\
\text { Pending }\end{array}$ \\
\hline US NRCS & $\begin{array}{l}\text { Farmland Conversion } \\
\text { Impact Rating Permit }\end{array}$ & $\begin{array}{l}\text { No farmlands impacted, } \\
\text { issued } 9 / 24 / 96\end{array}$ \\
\hline Montana DEQ & Energy siting approval & $\begin{array}{l}\text { Approved as an } \\
\text { auxiliary facility as part } \\
\text { of Express Pipeline } \\
\text { application } 8 / 96\end{array}$ \\
\hline Montana SLB & $\begin{array}{l}\text { Easements for state land } \\
\text { and navigable waters }\end{array}$ & No permits required \\
\hline SHPO & $\begin{array}{l}\text { Approval of Cultural } \\
\text { Report }\end{array}$ & Pending \\
\hline Montana FWP & Impact to Wildlife & Pending \\
\hline $\begin{array}{l}\text { Hill County } \\
\text { Conservation District }\end{array}$ & $\begin{array}{l}310 \text { permit for all } \\
\text { waterbody crossings }\end{array}$ & $\begin{array}{l}\text { Ruled "not a project", } \\
\text { issued 7/9/96 }\end{array}$ \\
\hline
\end{tabular}



September 23, 1996

Via Courier

\author{
INTERNATIONAL BOUNDARY COMMISSION \\ United States and Canada \\ Canadian Section \\ 615 Booth Street \\ Room 573 \\ OTTAWA, Ontario \\ KIA OE9
}

\title{
Attention: Mr. Noel Paquette, Engineer to the Commission
}

Dear Sirs:

Re: Request for Authorization by TransCanada Power Corp. ("TPC")

Pursuant to Section 5 of the International Boundary Act (the "Act"), IPC hereby submits for your approval an application for authorization to construct, install, operate and maintain a 69-kV electric transmission line across the Canadian and US International Boundary. There will be no additional facilities required at the Canada/USA border as the electric transmission line will cross the international border above ground at the Wildhorse Port of Entry.

The purpose of the proposed line is to supply electric energy to a pipeline pump station at Wildhorse, Alberta, Canada, owned by Express Pipeline timited ("Express Pipeline"). The pump station will serve a 785 mile crude oil pipeline that will transport Canadian-produced oil from Hardisty, Alberta, Carada, to Casper, Wyoming. The pipeline is scheduled to begin operation in January 1997 and will supply crude oil to refineries in the U.S. Midwest.

Hill County Electric Cooperative ("Hill County") will construct own, operate and maintain the facilities to be constructed on the U.S. side of the international border, and TransCanada Power Corp., a Canadian powermarketing company, will constuct, own, operate and maintain the connecting electric transmission line that will extend nine and one-half $(9.5)$ miles north to service Express Pipeline's Wildhorse crude oil pumping station on the Canadian side of the international border.

An application to the National Energy Board of Canada for a certificate authorizing construction and operation of this power line is being filed simultaneously herewith. In addition, Hill County has applied to the U.S. 
Page 2

September 24, 1996

International Boundary Commission

Attention: Mr. Noel Paquette

Department of Energy ("DOE") for Authority To Transmit Electric Energy To A Foreign Country ("EA-118"), and for a Presidential Permit in Compliance With Executive Order No. 10485 ("PP-118"). Both applications were Noticed in the Federal Register on August 5, 1996, Vol. 61, page 151. Hill County is anticipating DOE regulatory approval by mid-October 1996.

In support of our application, please find enclosed two original plans, dated September 3, 1996 and revised September 19, 1996, that reference the proposed electric transmission line to two international boundary monuments.

We would appreciate our request being considered by the International Boundary Commission at its earliest opportunity. Should you or your staff have any questions, please do not hesitate to contact the undersigned at (403) 262-0470.

Sincerely,

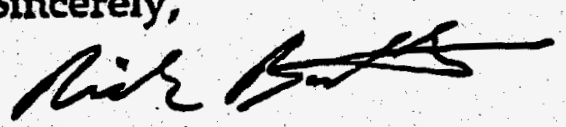

Rick Barteluk, Manager, Power Projects TransCanada Power Corp.

End. 
RESOURCE MANAGEMENT

INTERNATIONAL, INC.

June 3, 1996

Ms. Stephanie Utter

Billings Area Office

U.S. Bureau of Reclamation

P. O. Box 30137

Billings, MT 59107

Subject: Milk River Crossing Permits and Approvals

Dear Ms. Utter.

Resource Management International, Inc. (RMI) is sending this letter on behalf of the Hill County Electric Cooperative (Hill County) who is studying the feasibility of constructing a $69-\mathrm{kV}$ transmission line extending approximately 15 miles from the Havre, Montana area to the Canadian border. This line would provide electricity to the proposed Wild.Horse pumping station in Alberta. Wild Horse is one of the pump stations on the Express Pipeline, (highlighted in blue on the attached map).

Two alternate routes are being considered for Hill County's single woodpole $69-\mathrm{kV}$ transmission line (shown in pink on the attached map). These two routes would both cross the Milk River in the utility corridor adjacent to the Express Pipeline right-of-way (ROW). All lands affected are private or state, except federal lands in Sections 11 and 14 (T36N, R3W). Construction of the line would require a twenty-foot ROW easement across these federal lands along the Milk River. The least intensive route would be to erect the transmission line within the forty-foot temporary Express Pipeline ROW, following construction of the pipeline. We believe that this routing would represent the least new impacts to environmental and cultural resources, and is the preferred engineering routing as well.

From a review of land ownership, and consultation with Don Ogaard at BLM (Worland, Wyoming), it appears that these are Bureau of Reclamation (BOR) lands. Mr. Ogaard recommended we contact BOR for information on a BOR ROW easement.

As part of this proposed project, we will be preparing a NEPA EA for the Department of Energy (DOE). DOE will be the lead federal agency because of its action in issuing a Presidential Permit and export license for Hill County's export of power to Canada.

At Ms. Jabs suggestion, we have also contacted Michael Andrews for cultural resource coordination. He has been contacted by Peter Jensen, our archeologist, and Peter will follow up directly with him on the cultural resource requirements for the Hill County Co-op transmission line DOE Environmental Assessment (EA). 
Ms. Stephanie Utter

June 3, 1996

Page 2

We would like to begin the process to obtain the twenty-foot easements for Hill County's project on BOR land. Unless we hear otherwise, we will assume we have permission to perform biological surveys on BOR land along the Milk River. Paul Durzan or I will call you in the next few days to follow up.

Sincerely,

Andrea dogui for

Allen Crabtree

Senior Vice President

Enclosure

cc: Katherine Jabs, Bureau of Reclamation

Don Ogaard, Bureau of Land Management

Bob Beauchaine, Hill County

Russ Malsam, Heberly Associates 
U.S. Army Corps of Engineers

301 S. Park Drawer 10014

Helena, Montana 59626

(406) 441-1375
RECEIVED

SEP 191996

RMI - Sacramento

\section{Allen Crabtree}

Resource Management International, Inc.

P.O. Box 15516

Sacramento, California 95852-1516

Dear Mr. Crabtree:

Reference is made to Hill County Electric Cooperative's Department of the Army (DA) application for authorization to construct a transmission line crossing over an agricultural impoundment in Sections $22,23,26$, and 27, Township 36 North, Range 11 East, Hill County, Montana, and to also construct a transmission line crossing the Milk River in Sections 11, 12, 13, and 14, Township 36 North, Range 11 East, Hill County, Montana.

Under the authority of Section 404 of the clean water Act, Department of the Army permits are required for the excavation and discharge of fill material below the ordinary high water mark of our nation's rivers, streams, lakes or in wetlands.

Based on the information provided that there will not be any discharge of dredged/or other fill material below the ordinary high water mark of the Milk River or in a jurisdictional wetland, this office has determined that no Department of the Army permit is required. However, this does not eliminate the requirement to obtain other applicable federal, state, tribal, and local permits as applicable.

Should you have any questions, please call, and reference No Permit Required Letter 199690293.

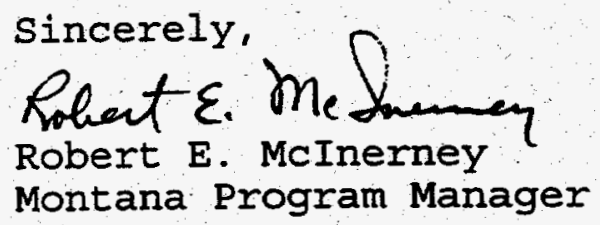

cc: Hill County Electric Cooperative

Hill County CD 


\section{RMI}

RESOURCE MANAGEMENT

I NTERNATIONAL, INC.

August 27, 1996

Mr. Steve Oddan

Biologist

U.S. Fish and Wildlife Service

2900 Fourth Avenue N., Room 301

Billings, MT 59101

Subject: Wild Horse 69-kV Transmission Line Biological Surveys

Dear Mr. Oddan:

Biological surveys of the proposed and alternative Wild Horse transmission line routes have been completed. Wildlife and botanical surveys were conducted by Jessica Martini and Jennifer Lyman on June 30, July 1, 16, 24 and 25, 1996. No species listed as endangered or threatened under the federal Endangered Species Act were encountered during the surveys. No special-status species or habitats identified by the Montana Natural Heritage Program as being of concern were observed within the proposed and alternative alignments.

During our conversation on June 5,1996 , the possibility of impoundments attracting waterfowl at the proposed crossing of the Milk River was the only concern you expressed regarding this project. As seen during our July 2, 1996, site visit, no impoundments are present in the Milk River canyon at the proposed crossing. No waterfowl were observed at the proposed crossing during any of the surveys.

Approximately two miles south of the Milk River, small numbers of waterfowl. [mallard (Anas platyrhynchos), gadwall (Anas strepera), double-crested cormorant (Phalacrocorax auritus), and killdeer (Charadrius vociferus)] were observed using an agricultural impoundment in section $23, \mathrm{~T} 36 \mathrm{~N}, \mathrm{R} 11 \mathrm{E}$. The proposed transmission line will not directly impact the impoundment, as lines will span the approximately 125-foot crossing at the west end of the impoundment. In order to reduce the potential for waterfowl strikes in this area, the transmission lines will be marked with helical wrappers to increase their visibility. We believe this measure will adequately mitigate potential impacts to waterfowl at this location. 
Mr. Steve Oddan

August 27, 1996

Page 2

If we do not receive a response from your office within 30 days, we will assume you are in agreement with our findings of less than significant impacts to wildlife and plant species. If you have any questions, please call Allen Crabtree or me at (916) 852-1300. Thank you for your attention to this matter.

Sincerely,

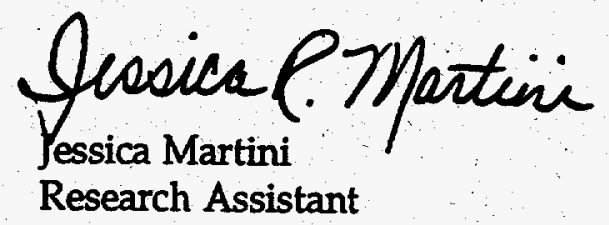




\section{FARMLAND CONVERSION IMPACT RATING}

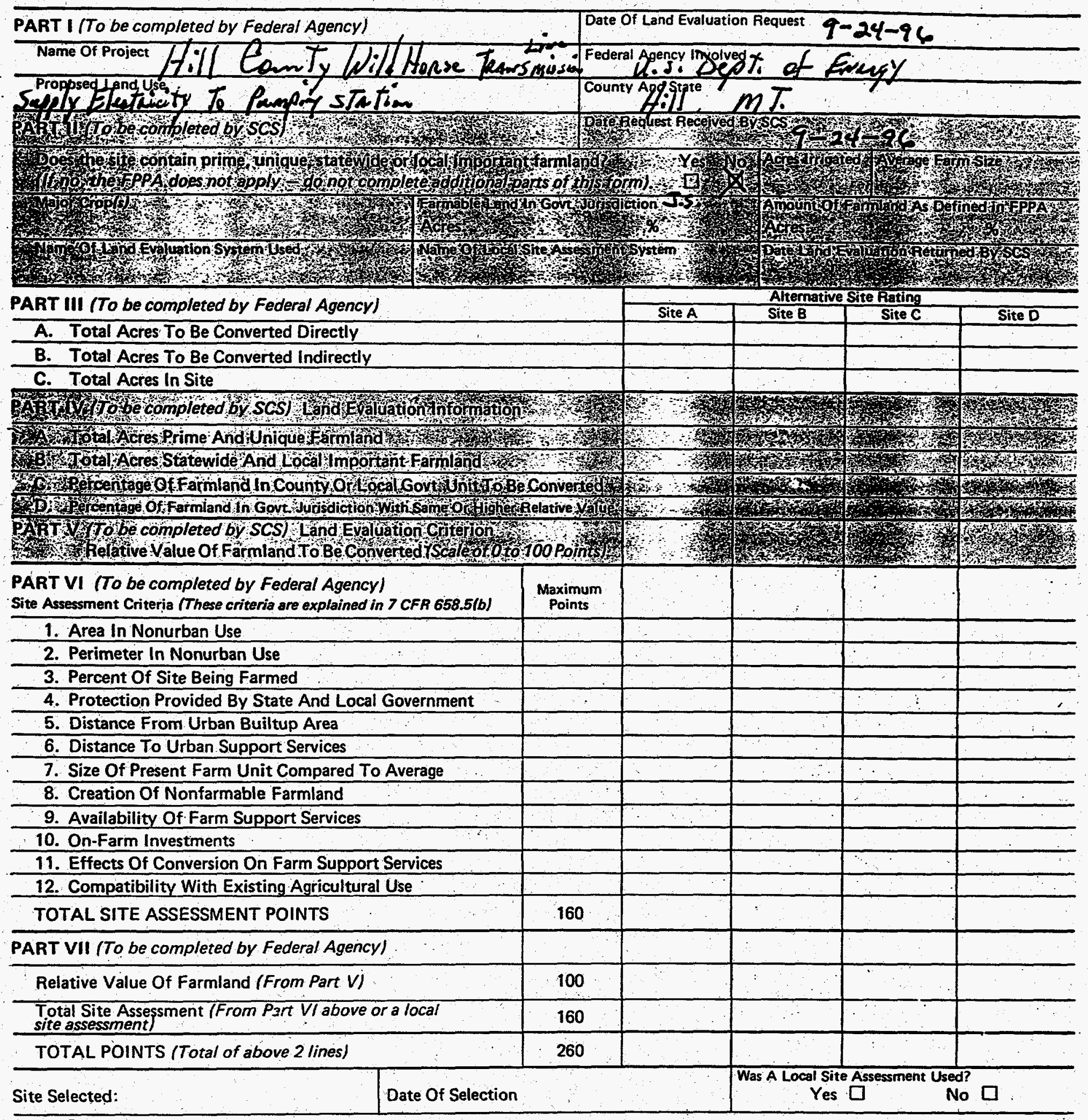

Reason For Selection: 


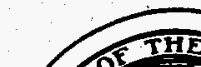

July 10, 1996

Mr. Jim Sands

HEBERLY \& ASSOCIATES

P O Box 1311

421 Fourth Street

Havre, MT 59501

RE:

Proposed Milk River Project, Section 13, T36N-R11E

Dear Jim:

In confirmation of our phone conversation this morning, the Milk River in the above listed location is not presently considered navigable. Therefore, you will not need an easement or license from us for your proposed project.

During our conversation, you did mention that there were may be some other state lands involved. This being the peak construction period, I urge you to submit your applications as soon as possible to avoid unnecessary delays in your project. Processing applications can take 90 days or longer.

If you need anything further, please feel free to call.

Sincerely,

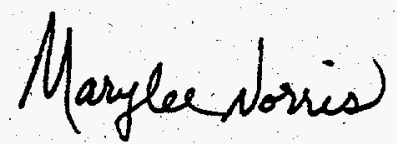

Marylee Norris, Supervisor

Special Uses Management Bureau

Trust Lands Management Division

c: Clive Rooney, Chief, Surface Management Bureau

Craig Roberts, Area Manager, NELO 


\section{RMI}

RESOURCE MANAGEMENT

INTERNTIONAL, INC.

August 27, 1996

Mr. Al Rosgaard

Biologist

Montana Department of Fish, Wildlife and Parks

360 Third Avenue, Room 202

Havre, MT 59501-0868

Subject: Wild Horse 69-kV Transmission Line Biological Surveys

Dear Mr. Rosgaard:

Biological surveys of the proposed and alternative Wild Horse transmission line routes have been completed. Wildlife and botanical surveys were conducted by Jessica Martini and Jennifer Lyman on June 30, July 1, 16, 24 and 25, 1996. No species.listed as endangered or threatened under the federal Endangered Species Act were encountered during the surveys. No special-status species or habitats identified by the Montana Natural Heritage Program as being of concern were observed within the proposed and alternative alignments.

During our conversation on June 5, 1996, the possibility of impoundments attracting waterfowl at the proposed crossing of the Milk River was the only concern you expressed regarding this project. As seen during our July 2, 1996, site visit, no impoundments are present in the Milk River canyon at the proposed crossing. No waterfowl were observed at the proposed crossing during any of the surveys.

Approximately two miles south of the Milk River, small numbers of waterfowl [mallard (Anas platyrhynchos), gadwall (Anas strepera), double-crested cormorant (Phalacrocorax auritus), and killdeer (Charadrius vociferus)] were observed using an agricultural impoundment in section $23, T 36 \mathrm{~N}, \mathrm{R} 11 \mathrm{E}$. The proposed transmission line will not directly impact the impoundment, as lines will span the approximately 125-foot crossing at the west end of the impoundment. In order to reduce the potential for waterfowl. strikes in this area, the transmission lines will be marked with helical wrappers to increase their visibility. We believe this measure will adequately mitigate potential impacts to waterfowl at this location. 
Mr. Al Rosgaard

August 27, 1996

Page 2

If we do not receive a response from your office within 30 days, we will assume you are in agreement with our findings of less than significant impacts to wildlife and plant species. If you have any questions, please call Allen Crabtree or me at (916) 852-1300. Thank you for your attention to this matter.

Sincerely,

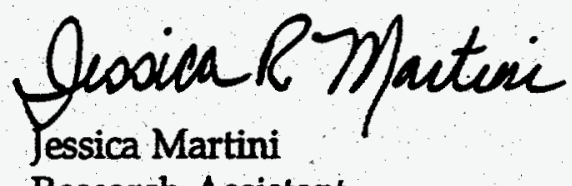

Research Assistant 


\section{HEBERLY AND ASSOCLATES \\ Consulting Englneer. \\ P.O. $\operatorname{Bax} 1311$ \\ 521 Fourth street \\ Bavre, Montana 59501 \\ Phone (406) 2656741}

July 10, 1996

Burl Miner

Hill County Electric Cooperative, Inc.

P.O. Box 2330

Havre, Montana 59501

Re: Milk River Crossing 310 Application

Dear Burl:

Please find enclosed a copy of the 310 application that was filed with the Natural Resources Conservation service. The permit was filed at the Board Heeting of the NRCS last night. The NRCS proclaimed that the permit was not a project, which means they gave their blessing on the transmission line crossing the river. They will be sending us a hard copy stating the none project" declaration.

If you have any questions, please contact me.

sincerely,

Heberly and Associates,

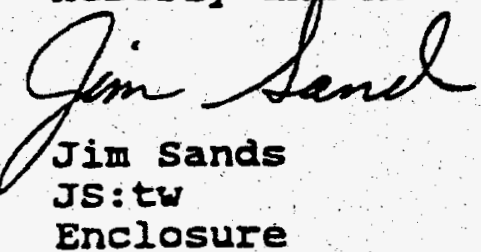

cc: Bob Beauchaine 


\section{STATE OF MONTANA \\ NATURAL STREAMBED AND LAND PRESERVATION ACT \\ 310 PERMIT \\ (Supervisors' Decision)}

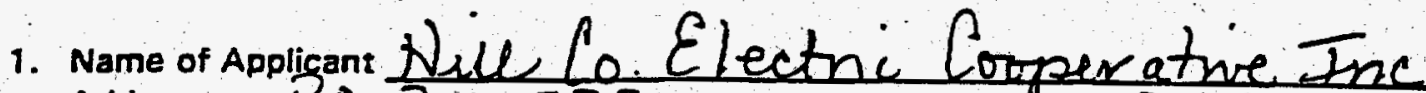
Address P.0. Box 2330 Perennial Stream City Harne, mat. 59501 State Zip

2. Supervisors' Decision (circle): Approved Denied

Approved w/ Modification

mille Ruser -

\section{Explanation:}

3. Work may not commence on a project for 15 days after receipt of this decision unless district has checked box below.
Waiver of 15-day Waiting Period

4. Permit Expiration Date

5. Supervisors' Signatures:

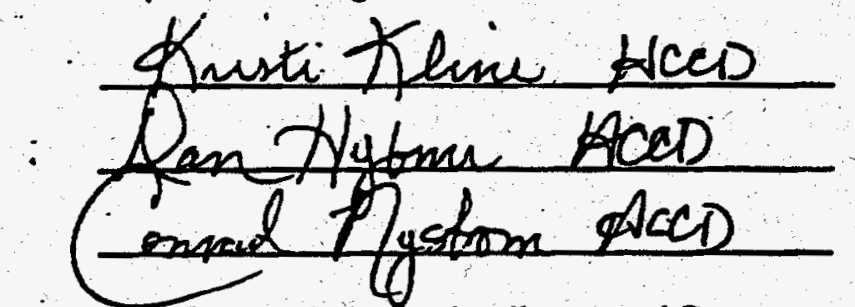

6. Date Transmitred to Applicant and Deparment Team Members

7. The applicant must agree to abide by the conditions of this permit by checking the appropriate box, signing below, and returning this form to the district office within 15 days.

1 hereby agree to proceed with the project in accordance with the approved application and will allow follow-up inspection.

D I hereby agree to proceed with the project in accordance with the modifications contained herein, and will allow follow-up inspection.

- I understand the project as proposed has been denied, and I may resubmit my application with modifications.

8. If the applicant disagrees with the supervisors' decision and wishes to formally resolve the dispute, the applicant must check the box below, sign, and return this form to the district within 5 working days.

D I disagree with the superivisors' decision and hereby request arbitration.

Signature of Applicant:

Printed or Typed Name:

Pefefa. Bem da

Date: July 12,1996 
STATE OF MONTANA

By:

NATURAL STREAMBED AND LAND PRESERYATION ACT

310 APPLICATION

(Notice of Proposed Project)

1. Name of Applicant Hill County Electric Cooperative, Ire

Address

P.0. Box 2330

Telephone No.

$(406) .265-7804$

Ciry/State/Zip Havre, Montana 59501

Starus of Applicant:

Landowner

Landowner's Agent

(8) Other (explain)

RUS Cooperative.

Name of landowner if different from applicant Bureau of Reclamation, Mark Albers

Address Billings, Montana Phone: (406)247-7312

2. Name of perennial stream at location of acoivity $:$ Milk River

Location of the proposed activity:

$y$ NW $y$ NW $y /$ Section County

Hi11 Township 36N Range 11E

3. Is this application for an activity that will be conducted annually? Yes No $x$.

4. Date activity is proposed to commence: $9-30-96$ Date activity is expected to be completed $10-4-96$

5. Describe proposed activity in detail and purpose of project. Attach plan and/or drawing of proposal. including site focation map.

See attachments for plan and drawing.

6. Pursuant to MCA $\$ 75-7-112(5)$ and 5 75-7-113(8), when a team member disagrees with the supervisors' decision the team member shall request that an arbitration panel as provided in 75-7-1 14 be appointed to hear the dispute an make a written decision regarding their decision. This request must be made in writing, and must be received by th. conservation districe within $\mathbf{5}$ working days af receipt of the supervisors' decision.

I, the undersigned. acknowledge that I have received and understand the Natural Streambed and Land Preservation Act rules of abitration and agree, in any dispures arising from the supervisors' decision, to abide by the rules of arbitration.

The applicant certifies that the statements appearing herein are to the best of the applicant's knowledge true and correct. d hereby authorizes the inspection of the project site by inspecting authorities.

Signature:<smiles>C1[Te]C2C[Te]1C2</smiles>

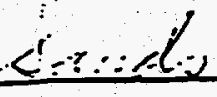
Dare $\frac{7-9-96}{\text { URSUANT TO RULES OF }}$ DISPUTES AARISING UNDER THIS APPLICATION ARE SURJECT TO ARBITRATON PURSUANT TO RULES OF ARBITRA TION AND APPLICABLE PROVISIONS OF THE UNIFORM ARBITRATION ACT, TITLE 
ATTACEMIENT TO

310 APPLICATION

\section{Milk River Power Iine Croseing:}

The power line crossing consiats of 6 wiras to be pulled across the Milk ziver. The wires will connect to a IH-5eD structure, a three pole etructure, conatructed on asch side of tho river. The three pole structures will be constructed approximately 100 to 200 feet From the edge of the river bank. Poles on either side of the three pole structures will be a IP-69G structure, a single pole atructure, apaced approximately 300 feet apart. A mechanical digger truck is used to auger a 30 inch by $B$ foot hole. The pole is placed in the hole. The soil is tarped, with mechanical tarpers around the hole. Any excess soil is banked around the pole to help shed water.

A rope puller machine will be used in the pulling process of the wires, as required in the "tension stringing" method. The actual length of pull will be approximately 6000 feat, with the river crossing being approximately 3000 feet from the wire real and, on the north side of the river. The rope puller machine will be positioned on the south side of the Milk river, approximately 3000 feet from the river crossing. Ropes will be throaded through pulleys hanging on each pole, from the pulling machine to the wire reels. An individual will walk the ropes acrose the river at the crossing point, at which point they will be pulled under tension to the wire reel. Once the rope reaches the wire reel it will be attached to the end of the wire and the wire is puiled under tension back to the pulling machine. The wire will then be spliced, pulled up to required tension, and secured. This procass will be repeated six times. See the following page for a diagram of tension stringing.

UsGs quad maps are included, showing the Milk river crossing and other drainage crossings that may be of concern. 


\section{APPENDIX E DESCRIPTION OF CONSTRUCTION}




\section{Wildhorse Transmission Line Description of Construction}

The wildhorse $69 \mathrm{KV}$ transmission line is designed for a single pole, horizontal post style of construction. This type of construction was chosen for its simplicity of design.

A field survey precedes construction. Elevations and distances are measured along the line route with the survey. This data is then used to develop plan and profile drawings. Poles are spotted using the plan and profiles to maintain a minimum of 23 feet of clearance. The maximum conductor sag is calculated. This is either with inch of lce coating the conductor, or operation of the conductor at a temperature of $167^{\circ} \mathrm{F}$. Whichever condition results in the greatest conductor sag controls the span length between poles. Poles are then field located using the span length distances developed with the plan and profile drawings. Field locations are indicated using a small $16^{\prime \prime}$ wood stake.

Construction begins with the poles. The Western Red Cedar poles are pre-drilled for the insulator mounting bolts. The poles are then full-length treated with a wood preservative. A tractortrailer hauls approximately twenty of the sixty foot poles from the treating plant to the line route. In areas adjacent to improved roads, a hydraulic crane mounted on the tractor unloads each pole adjacent to the planned pole location, or stake. Through rougher terrain, which in this case is the route through the Milk River valley, a 2-ton boom truck will be used to move poles to the line routing. A small two-wheeled trailer is used to haul three to four poles at a time to the staked locations.

After the poles are spotted, the contractor will frame the poles. Framing consists of adding the insulators, static wire supports and pole ground wire to the pole. A small two-ton truck with a hydraulic boom and wench is generally used for this. A one-ton truck is used to carry insulators, bolts, staples and miscellaneous hardware to the site. A four man crew accomplishes the pole framing.

Following the framing crew is a four to five man setting crew. A three-ton dual-axled truck generally is used. A hydraulic auger is mounted on this truck. This auger is used to dig a 30 inch hole eight foot deep. The boom on the digger truck is used to set the pole vertically into the hole. A small $\frac{j}{h}$ ton truck pulls a small trailer mounted air compressor. The air compressor is used in conjunction with mechanical tamping devices. Two men will shovel the augered dirt into the hole around the pole. Two men will use the mechanical tamps to compact the loose soil back to its original density. All excess soil is mounded around the pole to help shed water away from the pole. This helps to prolong the pole life by shedding excess molsture away from the wood pole. 
Stringing the conductor is the next stage of the project. For most of the route, a back-string and layup method of stringing is used. Four conductors (three phase and one static conductor) are installed on the poles. A two-ton truck, with a flat-bed trailer and four reel jacks, drives adjacent to the pole centerline. The conductor is laid out alongside the poles. A Iineman will climb each pole and bring two conductors over the top. The conductors are placed in travellers hung on the insulators. A travelier is a small block and sheave assembly thet helps to reduce friction when tensioning the conductors. After about one mile of conductor has been laid up in travellers, the conductor is pulled up to near desired tensions by a small $\frac{1}{4}$ ton truck. The conductor is snubbed off to a stable object, generally a pole base. A lineman will climb the pole and measure the line tension by means of an etched glass thermoweter and stop watch. Chain hoists attached to conductor grips are used to tighten the conductor. Once the conductor reaches a pre-determined tension, the conductor is tied in place. A trunnion style clamp is placed around the conductor and bolted to each insulator. To perform this task, the linemen either climb the poles or use a small bucket truck, when the terrain permits their use.

At the Milk River crossing and through rougher terrain, ropes are pulled out using small $\frac{3}{4}$ ton trucks. These ropes are laid up in a similar fashion as the methods previously described for backstringing. Once the ropes are in place, a tensioning drum is used to puIl up the rope. The rope is attached to the conductor. The conductor is pulled through the travellers (sheave). With this process, tension on the conductor is maintained which prevents the conductor from contact with the terrain or obstacles, such as trees or fences. This is to prevent any damage from abrasion to the conductor. The tensioner and conductor reels are mounted on twoton flatbed trucks positioned at each end of a pull. This necessitates two additional pieces of equipment in comparison to the back-string method. With the small conductor being used, tensioning is again accomplished with a thermometer and stop watch.

Log anchors are used to maintain tension on the conductors. These anchors are set using a small rubber-tired backhoe. A smail $\frac{z}{4}$ ton truck accompanies the backhoe to carry men and hardware to each anchor site. In areas with sandy soil, a screw type anchor will be installed. These anchors can be extended down to reach stable soil layers. All areas of disturbed soil will be reseeded using plant mixtures indigenous to the area.

Construction is accomplished using mainly small trucks. The largest piece of equipment will be a dual axled digger truck. No new roads are reguired for construction. Access to the route will utilize existing roads and trails. All the trucks utilized are generally all wheel drive.

construction is generally limited to about twelve man crews. The owner (Hill County Electric) requires an inspector on site to insure compliance with the material and drawing specifications. In 
addition, the Montana Department of Environmental Quality will have an inspector. The DEQ has issued environmental rules which must be cowplied with. These rules are designed to minimize impacts to the terrain being crossed. Hill county Electric obtains easements for all of its projects from the landowners. It is their policy not to pay for the easement. In order to maintain the ability to obtain easements, HCE understands that these projects cannot disrupt the land and the surrounding environment. With that in mind, HCE stresses that care be taken in all construction projects. 


\title{
FINDING OF NO SIGNIFICANT IMPACT
}

\author{
Hill County Electric Cooperative, Inc.
}

FE Dockets PP-118 and EA-118

The Department of Energy (DOE) is considering applications by Hill County Electric Cooperative, Inc. (Hill County), for a Presidential permit (FE Docket No. PP-118) and an electricity export authorization (FE Docket EA-118). Prior to issuing a Presidential permit or export authorization, the DOE must evaluate the environmental impacts of the activities that would result from such issuance pursuant to the National Environmental Policy Act of 1969 (NEPA) (42 U.S.C. 4321, et seq.). DOE has prepared an Environmental Assessment (EA), DOE/EA-1192 Wild Horse 69-KV Transmission Line for Hill County. The proposed action assessed in this EA is the issuance by DOE of the requested Presidential permit and electricity export authorization.

On July 12,1996 , and amended on July 25,1996 , Hill County filed applications with the Office of Fossil Energy (FE) of the DOE for a Presidential permit in order to construct, connect, operate, and maintain a 69-kilovolt ( $\mathrm{kV}$ ) electric transmission line. In addition, Hill County filed an application to export up to 6,000 kilowatts of electrical energy to Canada. The proposed transmission line will emanate from Hill County's North Gilford Substation in Montana and travel north approximately 17.5 miles paralleling existing roads and two-track trails nearly its entire U.S. length. The transmission line will cross the Milk River at the Express Pipeline rightof-way. The proposed project will connect with similar Canadian facilities, at the border, owned and operated by TransCanada Power Corporation (TCP), a Canadian power marketing company.

The proposed transmission line will provide electric energy to a pump station in the vicinity of Wild Horse, Alberta, Canada, owned by Express Pipeline Ltd. (Express Pipeline). The pump station in turn serves a crude oil pipeline that will transport Canadian-produced oil from Harcisty, Alberta, Canada, to Casper, Wyoming. The pipeline is scheduled to begin operation in January 1997 , and will supply crude oil to refineries in Wyoming and the midwest.

The proposed line is a radial circuit constructed as a single wood pole overhead transmission line designed in accordance with Rural Utilities Service (RUS) guidelines. The circuit would be operated at a nominal $69-\mathrm{kV}$ (line to line) and 60 hertz. Phase conductors would be 4/06/1 ACSR (Penguin). One conductor per phase would be used. The transmission line will be constructed with a $3 / 8^{\prime \prime}$ high-strength steel overhead static conductor (for lightning diversion). The line will be designed to the National Electrical Safety Code (NESC) for heavy loading parameters of onehalf inch ice and a four pound wind load. All NESC vertical and horizontal clearance will be met or exceeded.

In the course of preparing the EA, the DOE has consulted with the U.S. Department of Interior's Fish and Wildlife Service, the Bureau of Land Management, the State Historic Preservation Office of the State of Montana, and the Western Area Power Administration. These consultations 
resulted in comments from these agencies and identification of minor shortfalls in some areas of the draft EA. These comments were incorporated into the text of the final document.

In addition to the proposed action, Hill County considered several alternatives, including no action, two routing alternatives, and an alternate construction method. The DOE has addressed in the EA the impacts of the alternatives due to construction and operation of the transmission line. This EA is available on request.

\section{Conclusion}

Based on the information contained in the environmental assessment, DOE has determined that issuance of a Presidential permit and an electricity export authorization to Hill County, for the proposed actions, is not a major federal action significantly affecting the quality of the human environment and, therefore, does not require preparation of an environmental impact statement.

\section{Environmental Consequences of the Proposed Action}

The approximately 17.5 mile transmission line, paralleling existing roads and two-track trails, will be located in the section of the Missouri Plateau known as the Great Plain Physiographic Province. The section is characterized by flat to hummocky glacial till and local patches of outwash gravel and lake sand, silt, and clay which overlies mostly Cretaceous shale.

\section{Air Quality Impacts:}

o There are no air quality impacts because no powerplants are involved. None of the facilities will involve any polluting emissions.

o Impacts due to construction activities will be minor, short in duration and local in nature (road dust, exhaust emissions from construction equipment and other vehicles).

\section{Cultural Resources Impacts:}

- There will be minimal impacts, if any, on cultural sites. Sites of known cultural resources will be avoided. An archaeologist will be on-site during construction at the Milk River to monitor activities around cultural sites.

o Construction workers will be instructed about cultural sites and types of fossils they could encounter, and the steps to be taken if they uncover fossils anywhere during construction.

\section{Land Resource Impacts:}

o During construction, any disturbance of the ground surface or compaction would be diked or ripped as appropriate, and disturbed areas would be reseeded. All restoration 
will be in accordance with the Express Pipeline EIS Preliminary Restoration Plan (BLM, 1995).

o The transmission line will have little or no effect on agricultural land. Most poles will be placed outside cultivated land and construction will largely take place from roads and trails. There would be approximately sixteen wooden pole structures per mile with the average distance between structures of 320 feet. Any loss to farmland would be temporary.

- The route does not cross any major seismic areas and is not in areas where landslides have occurred.

o The proposed route does not cross any recreational or natural areas or affect dwellings or sites on the National Register for Historic Preservation. No existing residential, commercial, or industrial uses are affected. No aiport or associated flight activity will be affected.

\section{Water Resource Impacts:}

o The proposed route crosses the Milk River at the Express Pipeline right-of-way. The width of the Milk river at the crossing is approximately 150 feet. The agricultural impoundment is approximately 60 feet wide. The other intermittent and dry coulees are no wider than 30 feet. The transmission line will span over all these water bodies and their banks. No construction or operation activities will take place in streams, thus no impacts would occur.

- Any unavoidable impacts incurred during transmission line construction will be short-term and minor.

\section{Ecological Impacts:}

o The proposed route will have no construction or operation occurring in wetlands. No equipment would enter wetlands, and poles will be placed outside wetlands so conductors would overspan them.

- Construction of the transmission line could create increased erosion and sedimentation due to clearing of ground cover. Any vegetation disturbed during construction will be reseeded. No new access roads will need to be built. Vegetation will be restored according to Preliminary Restoration Plan contained in the BLM-prepared Express Pipeline EIS (February, 1996).

o The proposed crossing at the Milk River provides poor quality habitat for waterfowl. No waterfowl species were observed at the crossing during the survey and no significant impacts are expected. However, to decrease the potential for waterfowl 
collisions with the proposed transmission line, helical wrap markers will be placed on the lines to increase their visibility.

o Suggested raptor protection design (Raptor Research Foundation 1981) will be used in pole design to reduce the likelihood of raptor electrocutions.

\section{Secondary Environmental Concerns:}

- Neither the substation nor the transmission line will result in significant electric fields or ion generation. Potential effects can be reduced or eliminated by appropriate mitigation.

- The Montana County Noxious Weed Management Act will be adhered to during construction to reduce the possibility of spreading noxious weeds.

o No significant visual impacts are expected from the presence of the transmission line from any of the view points along the route, except for poles that will be visible on the horizon 3+ miles away from the viewshed on the north bluff of the Milk River.

o With regard to environmental justice, no impacts would occur due to the construction of the proposed transmission line along the proposed route.

For further information, contact:

William $\mathrm{H}$. Freeman

Office of Coal \& Power Systems

Coal \& Power IM/EX Activities,

(FE-52)

Office of Fossil Energy

U.S. Department of Energy

1000 Independence Avenue, SW

Washington, DC 20585-0350

Telephone (202) 586-5883
James C. Johnson

Office of Self Assessment, (FE-6)

Office of Fossil Energy:

U.S. Department of Energy

1000 Independence Avenue, SW

Washington, DC 20585

Telephone (202) 586-6540

Date Issued

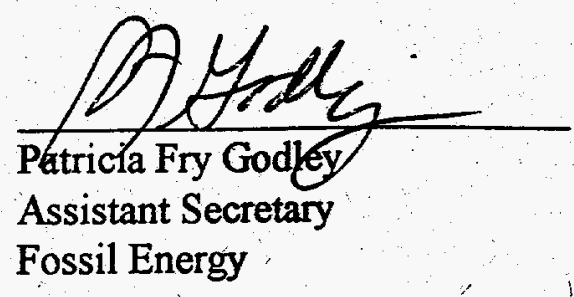

